\title{
Long-lived, stationary magmatism and pulsed porphyry systems during Tethyan subduction to post-collision evolution in the southernmost Lesser Caucasus, Armenia and Nakhitchevan
}

\author{
Robert Moritz $^{1, a}$, Hervé Rezeau ${ }^{1}$, Maria Ovtcharova ${ }^{1}$, \\ Rodrik Tayan ${ }^{2}$, Rafael Melkonyan ${ }^{2}$, Samvel Hovakimyan ${ }^{1,2}$, Vagif Ramazanov ${ }^{3, *}$, \\ David Selby ${ }^{4}$, Alexey Ulianov ${ }^{5}$, Massimo Chiaradia ${ }^{1}$ and Benita Putlitz ${ }^{5}$
}

${ }^{1}$ Earth and Environmental Sciences, University of Geneva, Rue des Maraîchers 13, 1205 Geneva, Switzerland

${ }^{2}$ Institute of Geological Sciences, National Academy of the Republic of Armenia, Baghramyan Avenue 24, 0019 Yerevan, Armenia

${ }^{3}$ Geological Department, Baku State University, Z. Khalilov St. 23, Az1145, Baku, Azerbaijan Republic

${ }^{4}$ Department of Earth Sciences, University of Durham, DH1 3LE United Kingdom

${ }^{5}$ Institute of Earth Sciences, University of Lausanne, Géopolis, 1015 Lausanne, Switzerland

* deceased May $7^{\text {th }} 2014$

a corresponding author: Robert MORITZ, University of Geneva, Rue des Maraîchers 13, 1205 Geneva, Switzerland; e-mail: robert.moritz@unige.ch 


\begin{abstract}
The composite Meghri-Ordubad and Bargushat plutons of the Zangezur-Ordubad region in the southernmost Lesser Caucasus consist of successive Eocene to Pliocene magmatic pulses, and host two stages of porphyry Cu-Mo deposits. New high-precision TIMS U-Pb zircon ages confirm the magmatic sequence recognized by previous $\mathrm{Rb}-\mathrm{Sr}$ isochron and whole-rock $\mathrm{K}-\mathrm{Ar}$ dating. A $44.03 \pm 0.02$ Ma-old granite and a $48.99 \pm 0.07$ Ma-old granodiorite belong to an initial Eocene magmatic pulse, which is coeval with the first stage of porphyry $\mathrm{Cu}-\mathrm{Mo}$ formation at Agarak, Hanqasar, Aygedzor and Dastakert. A subsequent Oligocene magmatic pulse was constrained by $\mathrm{U}-\mathrm{Pb}$ zircon ages at $31.82 \pm 0.02 \mathrm{Ma}$ and $33.49 \pm 0.02 \mathrm{Ma}$ for a monzonite and a gabbro, and a late Miocene porphyritic granodioritic and granitic pulse yielded ages between $22.46 \pm 0.02 \mathrm{Ma}$ and $22.22 \pm 0.01 \mathrm{Ma}$, respectively. The Oligo-Miocene magmatic evolution broadly coincides with the second porphyry-Cu-Mo ore deposit stage, including the major Kadjaran deposit at 26-27 Ma.
\end{abstract}

Primitive mantle-normalized spider diagrams with negative $\mathrm{Nb}$, Ta and $\mathrm{Ti}$ anomalies support a subduction-like nature for all Cenozoic magmatic rocks. Eocene magmatic rocks have a normal arc, calc-alkaline to high-K calc-alkaline composition, early Oligocene magmatic rocks a high-K calc-alkaline to shoshonitic composition, and late Oligocene to Mio-Pliocene rocks are adakitic and have a calc-alkaline to high-K calc-alkaline composition. Ragiogenic isotopes reveal a mantle-dominated magmatic source, with the mantle component becoming more predominant during the Neogene. Trace element ratio and concentration patterns (Dy/Yb, Sr/Y, La/Yb, Eu/Eu*, Y contents) correlate with the age of the magmatic rocks. They reveal combined amphibole and plagioclase fractionation during the Eocene and the early Oligocene, and amphibole fractionation in the absence of plagioclase during the late Oligocene and the Mio-Pliocene, consistent with Eocene to Pliocene progressive thickening of the crust or increasing pressure of magma differentiation. Characteristic trace element and isotope systematics (Ba vs. $\mathrm{Nb} / \mathrm{Y}, \mathrm{Th} / \mathrm{Yb}$ vs. $\mathrm{Ba} / \mathrm{La},{ }^{206} \mathrm{~Pb} /{ }^{204} \mathrm{~Pb}$ vs. Th/ $\mathrm{Nb}, \mathrm{Th} / \mathrm{Nb}$ vs. $\delta^{18} \mathrm{O}$, $\mathrm{REE}$ ) indicate that Eocene magmatism was dominated by fluid-mobile components, whereas Oligocene and Mio-Pliocene magmatism was dominated by a depleted mantle, compositionally modified by subducted sediments.

A two-stage magmatic and metallogenic evolution is proposed for the Zangezur-Ordubad region. Eocene normal arc, calc-alkaline to high-K calc-alkaline magmatism was coeval with extensive Eocene magmatism in Iran attributed to Neotethys subduction. Eocene subduction resulted in the emplacement of small tonnage porphyry Cu-Mo deposits. Subsequent Oligocene and Miocene high-K calc-alkaline and shoshonitic to adakitic magmatism, and the second porphyry $\mathrm{Cu}-\mathrm{Mo}$ deposit stage coincided with Arabia-Eurasia collision to postcollision tectonics. Magmatism and ore formation are linked to asthenospheric upwelling along translithospheric, transpressional regional faults between the Gondwana-derived South 
Armenian block and the Eurasian margin, resulting in decompression melting of lithospheric mantle, metasomatised by sediment components during the previous Eocene subduction event.

\section{Introduction}

The Tethyan orogenic belt was formed during convergence of the African-Arabian and Eurasian plates, and included abundant microplates (e.g. Golonka, 2004; Barrier and Vrielynck, 2008; Adamia et al., 2011; Rolland et al., 2012). This complex converging system resulted in Jurassic-Cretaceous and Paleogene subduction-related magmatism and ore formation, followed by various collision to post-orogenic magmatic and ore forming events throughout the Cenozoic (e.g. Marchev et al., 2005; Von Quadt et al., 2005; Perelló et al., 2008; Yigit, 2009; Moritz et al., 2014; Hou et al., 2015; Richards, 2015).

The Zangezur-Ordubad region of the southernmost Lesser Caucasus, along the Armenian and Nakhitchevan borders with Iran (Fig. 1), is a unique location along the Tethyan orogenic belt where magmatism remained stationary from an Early Paleogene subduction setting to a Neogene post-collision environment, in a place where a Gondwana-derived terrane collided with the Eurasian margin (Fig. 2). This resulted in a long-lived, Eocene to Pliocene pulsed magmatic system generating the composite Meghri-Ordubad and Bargushat plutons at the contact of the Gondwana-derived South Armenian block with the Kapan zone (Fig. 3). With an area of about $1400 \mathrm{~km}^{2}$, they form the largest pluton cluster along the Lesser Caucasus (Karamyan et al., 1974; Tayan et al., 1976; Babazadeh et al., 1990; Melkonyan et al., 2008). The composite Meghri-Ordubad and Bargushat plutons are also exceptional because they host within a small area several stages of Eocene to Miocene precious and base metal epithermal and porphyry Cu-Mo deposits (Bagdasaryan et al., 1969; Babazadeh et al., 1990; Melkonyan et al. 2010; Moritz et al., 2013). The evolution and setting of the Zangezur-Ordubad region of the southernmost Lesser Caucasus is comparable to the Himalayan setting, where protracted Mesozoic to Cenozoic magmatism was also accompanied by pulsed porphyry deposit emplacement (e.g. Hou et al., 2015).

The Lesser Caucasus is a key area to understand the lateral connection of the Western and Central Tethyan orogenic and metallogenic belt (Jankovic 1977, 1997; Richards, 2015), including the Balkans, Rhodopes and Taurides-Anatolides with the Iranian belts. In particular, the Meghri-Ordubad and Bargushat plutons, studied in this contribution in the southernmost Lesser Caucasus, constitute the northern extension of the Iranian Alborz and UrumiehDokhtar magmatic and metallogenic belts (Fig. 1). The link of the Lesser Caucasus with the later magmatic arcs is still not well understood, as well as the nature of the widespread Eocene to recent magmatic activity along the Lesser Caucasus (Sosson et al., 2010). 
This study is based on a comprehensive lithogeochemical study from the Zangezur-Ordubad region, spanning Eocene to Pliocene magmatic rocks, complemented by a whole-rock $\mathrm{Sr}, \mathrm{Nd}$, $\mathrm{Pb}$ and $\mathrm{O}$ isotope geochemistry investigation, and high-precision TIMS U-Pb zircon dating of selected and representative magmatic events. The new major, trace element, isotope and radiometric age data of this study allow us to reconstruct the Eocene to Pliocene magmatic evolution and its link to major, pulsed ore formation events in the Zangezur-Ordubad region. This evolution is discussed within the Tethyan framework, in particular, with respect to the Iranian magmatic belts and the overall geodynamic and metallogenic evolution during the final subduction stages of the Neotethys, and the ultimate collision between Arabia and Eurasia.

\section{Regional Geological Setting}

\subsection{Geodynamic setting}

The Lesser Caucasus is a segment of the Tethyan orogenic belt (Fig. 1), and is the consequence of north- to northeast-verging Jurassic-Cretaceous subduction of the Neotethys beneath the Eurasian plate (Kazmin et al., 1986; Zonenshain and Le Pichon, 1986; Rolland et al., 2011), followed by Late Cretaceous collision with the Gondwana-derived South Armenian block (Rolland et al., 2009 a, b), and a jump of the active Neotethys subduction zone to the southwest of the Turkish Bitlis-Pütürge massif (Kazmin et al., 1986; Zonenshain and Le Pichon, 1986; Rolland et al., 2012). East-verging Neotethys subduction and final Cenozoic convergence of the Eurasian and Arabian plates resulted in an Eocene magmatic climax, and was followed by collisional to post-collisional tectonics and magmatism from the Oligocene to the Pliocene (Khain, 1975; Gamkrelidze, 1986; Kazmin et al., 1986; Lordkipnadze et al., 1989; Sosson et al., 2010). An additional southwest-verging subduction zone of the Neotethys beneath the Gondwana-derived South Armenian block during the Middle-Late Jurassic to Early Cretaceous is also suggested by Melkonyan et al. (2000) and Hässig et al. (2015). The final collision between Arabia and Eurasia is widely debated and interpretations vary from Late Cretaceous (Mohajjel and Ferguson, 2000) to Miocene (McQuarrie et al., 2003; Guest et al., 2006; Okay et al., 2010). However, a majority of recent contributions favour an Upper Eocene-Lower Oligocene age (40-25 Ma) for the initial collision in the Caucasian-Zagros region (Vincent et al., 2005; Allen and Armstrong, 2008; Agard et al. 2011; Ballato et al., 2011; Verdel et al., 2011, McQuarrie and van Hinsberger, 2013).

Indentation tectonics has shaped the geometry of the Lesser Caucasus (Philip et al., 1989). According to paleotectonic maps of the Middle East published by Barrier and Vrielynck (2008; Fig. 2), the composite Meghri-Ordubad and Bargushat plutons are located along an indenter corner formed during Late Cretaceous collision of the South Armenian block with 
the Eurasian margin (orange-filled black circle in Fig. 2a). The paleotectonic maps document a complex Early Cenozoic subduction geometry with an $\sim$ EW-trending subduction zone to the south of the Turkish Bitlis-Pütürge massif coexisting and merging with a NW-striking subduction zone located along the Iranian Sanandaj-Sirjan block (see BPM and SSB, respectively, in Figs 2b-c), before final Arabia-Eurasia collision (Figs 2d-e).

\subsection{Tectonic and geologic setting of the Lesser Caucasus}

The Lesser Caucasus consists of three main tectonic elements (Fig. 1), including: the Eurasian plate margin, the Sevan-Akera suture zone, and the South Armenian block (Sosson et al., 2010; Adamia et al., 2011; Eppelbaum and Khesin, 2012). The Eurasian plate margin of the Lesser Caucasus is also known as the Transcaucasian microcontinent, and consists of the $\sim 350$ km-long Somkheto-Karabakh belt (Fig. 1) or Bayburt-Karabakh belt; Yilmaz et al., 2000) and the $\sim 70$ km-long Kapan zone or block (Fig. 3a; Gevorkyan and Aslanyan, 1997; Mederer et al., 2013). Both tectonic zones have similar geologic and tectonic characteristics and are interpreted as a discontinuous Jurassic to Cretaceous calc-alkaline island-arc during Neotethyan subduction (Sosson et al., 2010; Adamia et al., 2011), segmented by sublatitudinal strike-slip faults (Kazmin et al., 1986; Gabriyelyan et al. 1989; see SSF in Fig.1), and with paroxysmal volcanic activity during the Bajocian-Bathonian and the Kimmeridgian (Kazmin et al., 1986; Achikgiozyan et al. 1987; Lordkipanidze et al., 1989; Ismet et al., 2003; Mederer et al., 2013). Neoproterozoic to Paleozoic metamorphic and granitic basement rocks, covered by rare Jurassic sedimentary rocks, are exposed along the Somkheto-Karabagh range in the Loki, Khrami, Dzirula, and Akhum-Asrikchai massifs (Baghdasaryan et al., 1978; Shengelia et al., 2006; Zakariadze et al., 2007; Mayringer et al., 2011). Significant uplift and denudation during the Lower Cretaceous (Sosson et al., 2010) was followed by deposition of Upper Cretaceous and Paleogene sedimentary and volcanic rocks (Aslanyan, 1958; Achikgiozyan et al. 1987). In the north, the dominantly Upper Cretaceous extremity of the SomkhetoKarabakh belt within Georgian territory is known as the Artvin-Bolnisi zone (Fig. 1; Gamkrelidze, 1986; Yilmaz et al., 2000), and documents progressive northeastward migration of magmatism during the Late Cretaceous (Roland et al., 2011).

The Gondwana-derived South Armenian block is located to the southwest of the SomkhetoKarabakh belt and the Kapan block (Kazmin et al., 1986; Sosson et al., 2010), and is mainly exposed in southwestern Armenia, Nakhitchevan and the Tsaghkuniats (or Miskhana) massif, north of Yerevan (Fig. 1; Shengelia et al., 2006; Hässig et al., 2015). This block is also known in earlier contributions as South Armenian subplatform (Eppelbaum and Khesin, 2012), Nakhitchevan-South Armenia (Adamia et al., 2011) and Iran-Afghanian terrane (Gamkrelidze, 1997; Gamkrelidze and Shengelia, 2007). It includes the Miskhan-Zangezur, 
Yerevan-Ordubad, Araks and Paleozoic-Triassic Daralagez tectonic zones described in other contributions (e.g. Khain, 1975; Gamkrelidze, 1986; Zonenshain and Le Pichon, 1986; Saintot et al., 2006). The Meghri-Ordubad and Bargushat composite plutons investigated in this study were emplaced within the Miskhan-Zangezur zone, in the easternmost part of the South Armenian block, along the boundary with the Kapan block (Fig. 3a). The South Armenian block consists of Proterozoic metamorphic basement rocks, and an incomplete succession of Devonian to Jurassic sedimentary and volcanogenic rocks, unconformably covered by Cretaceous sedimentary and volcanic rocks (Belov, 1968; Kazmin et al., 1986; Sosson et al., 2010). Palaeozoic stratigraphic and lithological characteristics of the South Armenian block differ from the ones of the Eurasian margin and support a Gondwanian origin according to Sosson et al. (2010). Palaeomagnetic data indicate the presence of a 2700 $\pm 600 \mathrm{~km}$ wide ocean between both tectonic zones during the Early Jurassic (Bazhenov et al., 1996; Gamkrelidze and Shengelia, 2007). Barrier and Vrielynck (2008), Sosson et al. (2010), and Hässig et al. (2013 a, b, 2015) group the South Armenian block together with the Eastern Anatolian platform (e.g. Figs 2a-c), and interpret it as the northeastern part of the Tauride microcontinent since the Jurassic. By contrast, Adamia et al. $(1981$; 2011) include the South Armenia terrane together with the Sanandaj-Sirjan zone into the Central Iranian platform since the Jurassic, an interpretation which is shared by Golonka (2004) and Alavi (2007).

The ophiolite sequence of the Sevan-Akera zone outlines the suture zone between the Eurasian Somkheto-Karabakh belt and the Gondwana-derived South Armenian block (Fig. 1; Galoyan et al., 2009; Rolland et al., 2010; Hässig et al., 2013a). Obduction of the ophiolites was dated between 88 and 83 Ma (Galoyan et al., 2007; Rolland et al., 2010), and final collision between the Eurasian margin and the South Armenian block at 73-71 Ma (Rolland et al., 2009 a, b). The Sevan-Akera ophiolite is correlated with the Izmir-Ankara-Erzincan suture zone of northern Anatolia (IAES in Fig. 1; Yilmaz et al., 2000; Hässig et al., 2013b), and with ophiolites of the Iranian Zagros range (Fig. 1; Galoyan et al., 2009; Rolland et al., 2009a).

Evidence for a suture zone is more equivocal in the southernmost Lesser Caucasus between the Kapan and the South Armenian blocks, where the composite Meghri-Ordubad and Bargushat plutons are located (Fig. 3). The tectonic zone separating both blocks from each other is known as Ankhavan-Zangezur fault, and also locally as Khustup-Giratakh fault (Fig 3). It includes ultramafic rock, gabbro, spilite, andesite and radiolarite of the Zangezur tectonic mélange, which is imbricated with Late Precambrian to Early Cambrian metamorphic rocks and Devonian and Permian limestone and terrigenous rocks (Belov, 1969; Khain, 1975). Knipper and Khain (1980) and Burtman (1994) interpret the Zangezur tectonic mélange as remains of an ophiolite. Hässig et al. (2013a) correlate the Zangezur tectonic mélange zone with the Sevan-Akera ophiolite, although, relationships are hidden by Cenozoic molasse and volcanic rocks (Fig 1; Khain, 1975; Burtman, 1994). 


\subsection{Relationship of Iranian magmatic belts with the southernmost Lesser Caucasus}

The Zangezur-Ordubad region in the southernmost Lesser Caucasus is the merging location of the Cenozoic Iranian Urumieh-Dokhtar and Alborz magmatic belts (Figs 1 and 2c). Contrasting interpretations prevail about the geodynamic relationships of the Iranian belts. Vincent et al. (2005), Ballato et al. (2011), Verdel et al. (2011), Asiabanha and Foden (2012), and Chiu et al. (2013) link the Alborz and the Urumieh-Dokhtar magmatic belts to one single Neotethyan subduction, with the former being the back-arc and the later the main volcanic arc. By contrast, Alavi (2007), Azizi and Jahangiri (2008), Azizi and Moinevaziri (2009), Mokhtari et al. (2010) and Aghazadeh et al. (2011) attribute the Urumieh-Dokhtar and Alborz arcs to two separate, but parallel subduction zones, located on each side of the northweststriking Tabriz-Takestan fault (Fig. 1). According to the later scenario, the western UrumiehDokhtar belt is the product of Neotethys subduction, whereas the eastern magmatic Alborz belt is linked to eastward subduction beneath the Alborz-Azerbaijan range of an oceanic plate, the remnant of which is the Khoy ophiolite in northwestern Iran (Fig. 1; Hassanipak and Mohamad Ghazi, 2000; Ghazi et al., 2003; Juteau, 2004; Khalatbari-Jafari et al., 2006).

The continuity of the Iranian Cenozoic magmatic ranges into the southernmost Lesser Caucasus, where the Meghri-Ordubad and Bargushat plutons are located, is interrupted by the northeast-trending, orogeny-transverse and still active Araks strike-slip fault (Figs 1 and 3a; Zamani and Masson, 2014). The age of this fault is uncertain (Sosson et al., 2010), and it remains unknown whether it is a recent tectonic feature or if it was active before the onset of the collision between Eurasia and the South Armenian block (e.g. during the Upper Cretaceous, see Fig. 13 in Sosson et al., 2010, and Fig. 8 in Hässig et al., 2013a). Vincent et al. (2005) correlate the structures of the southernmost Lesser Caucasus with the ones of the Iranian Alborz range along the arcuate Talysh mountains. This interpretation is shared by Gamkrelidze (1986), Zonenshain and Le Pichon (1986), and Brunet et al. (2003), who link the Yerevan-Ordubad tectonic zone with the Talysh basin along the Caspian Sea (Fig. 1).

The Talysh range, the Alborz and the Lesser Caucasus underwent similar tectonic evolutions during the Cenozoic. The Talysh mountains and the adjoining Alborz range are interpreted as back-arc systems during the Eocene, followed by Late Eocene to Early Oligocene basin inversion, uplift and transpression attributed to the initiation of the Arabian-Eurasian collision (Ismail-Zadeh et al., 1995; Brunet et al., 2003; Vincent et al., 2005; Adamia et al., 2010; Ballato et al., 2010; Verdel et al., 2011; Asiabanha and Foden, 2012). In the Lesser Caucasus, Paleocene to late-Middle Eocene thick molasse series were deposited in a foreland basin to the southwest of the Somkheto-Karabagh belt (Fig. 1), and subsequently underwent lateMiddle Eocene to Miocene shortening, producing northwest-trending folds and thrust belts (Sosson et al., 2010). The molasse basin was deformed along thrust and décollement faults, with pre-existing normal faults being reactivated as reverse faults (Sosson et al., 2010). 


\section{Tectonic and geological setting of the Zangezur-Ordubad region}

The Zangezur-Ordubad region sites astride on the territories of southern Armenia and Nakhitchevan (Fig. 3a). Its eastern boundary along the Kapan block is the northwest-trending, dextral strike-slip Khustup-Giratakh fault, which includes the Zangezur tectonic mélange (Tayan et al., 1976; Fig. 3). The Zangezur-Ordubad region includes the eastern uplifted Zangezur block and the western downthrown Nakhitchevan block, separated from each other by the northwest-trending dextral strike-slip Ordubad-Salvard fault (Fig. 3b). The later is a segment of the regional Yerevan-Ordubad fracture zone, which is active since the Eocene (Aslanyan, 1958; Tayan et al., 1976).

Devonian, Permian, Jurassic and Lower Cretaceous sedimentary rocks outcrop in the eastern part of the Zangezur block (Belov, 1968), and Upper Cretaceous and Paleocene terrigenous sedimentary rocks are exposed in both Zangezur and Nakhitchevan blocks (Fig. 3b). An up to $2.5 \mathrm{~km}$ thick sequence of (Paleocene? to) Lower Eocene terrigenous flysch of the Piramsar suite is overlain by Middle Eocene terrigenous sedimentary and pyroclastic rocks of the Dalichai and Bagatsar suites, and voluminous calc-alkaline to subalkaline basalt, andesite, and trachyandesite of the Kaputjugh suite. They are accompanied by sub-volcanic bodies, and are predominantly exposed within the uplifted Zangezur block. Upper Eocene to Oligocene olivine basalt to andesite of the Geghakar suite are mostly exposed in the downthrown Nakhitchevan block, and are overlain by Oligo-Miocene molasse-type rocks, and MioPliocene sandy carbonate, volcanic and terrigenous rocks of, respectively, the Nor-Arevik, Salvard and Sisian suites (Fig. 3b; Djrbashyan et al., 1976; Tayan et al., 1976).

The composite Meghri-Ordubad and Bargushat plutons intrude pre-Middle Eocene rocks, and outcrop predominantly in the uplifted Zangezur block (Fig. 3b), with subordinate intrusions exposed in the downthrown Nakhitchevan block. Karamyan et al. (1974) and Tayan et al. (1976) recognized successive, pulsed Eocene to Miocene magmatic stages based essentially on field relationships and supported by radiometric dating (Fig. 4). Olivine gabbro is described as the first magmatic stage with a whole-rock K-Ar age of $41.4 \pm 3.5 \mathrm{Ma}$ (Ghukasyan, 1966). Two other stages were subdivided into, respectively, gabbro-monzonitesyenite (alkaline and nepheline-bearing) and gabbro-diorite-granodiorite-syenogranite intrusive complexes, yielding $\mathrm{Rb}-\mathrm{Sr}$ isochron ages between $45.3 \pm 3.5 \mathrm{Ma}$ and $38.3 \pm 1.0 \mathrm{Ma}$ (Ghukasyan et al., 2006; Melkonyan et al., 2008, 2010). A subsequent monzonitic stage was dated between $32.7 \pm 5.7$ and $30.0 \pm 0.4$ Ma by Rb-Sr isochrons (Ghukasyan et al., 2006; Melkonyan et al., 2008). The youngest stage consists of Miocene porphyritic granitegranodioritic dated at $22.8 \pm 2.1$ Ma by a Rb-Sr isochron (Melkonyan et al., 2008), and includes abundant dike generations, mainly outcropping in the Kadjaran mining district (Fig. 3b; Harutunyan et al., 2002). Abundant K-Ar mineral separate and whole-rock ages generally support the Rb-Sr ages and the successive magmatic pulses (Fig. 4; Melkonyan et al., 2008, 
2010). Magmatic activity continued during the Pliocene as evidenced by clasts of Pliocene Nor-Arevik sedimentary rocks in dacite along the Meghri-Tey graben-synclinal (Tayan, 1998; Fig. 3b). According to Tayan et al. (1976), emplacement of the composite Meghri-Ordubad and Bargushat plutons was contemporaneous with progressive uplift of the Zangezur block.

North-south-, roughly east-west- and southwest-trending faults with both vertical and strikeslip movements predominate within the Meghri-Ordubad and Bargushat plutons (Fig. 3b; Tayan et al., 1976; Tayan, 1984; Hovakimyan and Tayan, 2008; Hovakimyan et al., 2014a, b). They are interpreted as Oligocene in age, and were reactivated during the Mio-Pliocene. They controlled the formation of Cenozoic volcano-sedimentary basins, the emplacement of magmatic rocks, including dikes, and the location of molybdenum, copper and gold deposits (Mkrtchyan et al., 1969; Tayan et al., 1976; Tayan, 1998; Hovakimyan and Tayan, 2008; Hovakimyan et al., 2014a, b). The central, north-south-trending 3.5 to $4 \mathrm{~km}$-wide Meghri-Tey graben-synclinal structure (Tayan et al., 1986, 2005; Tayan, 1998; Hovakimyan and Tayan, 2008), bordered to the west by the north- to northwest-trending Tashtun fault, controls the majority of the ore deposits of the Meghri-Ordubad pluton (Hovakimyan et al., 2014a, b; Fig. $3 b)$. The present day graben geometry is mainly Mio-Pliocene in age, and was filled by Pliocene lacustrine-type sedimentary rocks of the Nor-Arevik formation. Hovakimyan and Tayan (2008) attribute the origin of the main tectonic structures of the Meghri-Ordubad pluton to southwest-striking compression and northwest-striking extension, which correlate with the regional orientation of structures in the Lesser Caucasus related to Arabia-Eurasia convergence (Avagyan et al., 2005). In the southern part of the Meghri pluton at Agarak (Fig. $3 b$ ), Eocene magmatic rocks are overthrusted on Pliocene sedimentary rocks of the Nor Arevik formation along the north-south-striking Spetri fault, and is evidence for compression subsequent to Mio-Pliocene graben formation.

\section{Metallogenic setting of the Lesser Caucasus and the Zangezur-Ordubad region}

Ore deposits were formed during the different stages of the geodynamic evolution of the Lesser Caucasus. The initial metallogenic evolution is related to the long-lasting JurassicCretaceous subduction of the Tethys along the Eurasian margin. Copper-pyrite, $\mathrm{Cu}-\mathrm{Au}$ and polymetallic stratiform, vein-type and stockwork ore bodies are hosted by Middle Jurassic volcanic and volcano-sedimentary rocks of the Somkheto-Karabakh belt and the Kapan zone in the Alaverdi, Mehmana and Kapan mining districts (A, M and K in Fig.1). Their genetic interpretation is still open to question, and varies from volcanogenic massive sulphide (VMS) to porphyry-epithermal ore styles (Kekelia et al., 2004; Mederer et al., 2014). Early Cretaceous porphyry $\mathrm{Cu}$ and associated precious metal epithermal deposits, along the Somkheto-Karabakh belt, occur at Teghout next to the Alaverdi district ( $T$ in Fig.1; Amiryan 
et al., 1987), at Gedabek, Gosha and Chovdar (G, Go and C in Fig.1; Babazadeh et al., 1990; Hemon et al., 2012), and in the Kapan district at the Shikahogh prospect ( $\mathrm{K}$ in Fig. 1; Achikgiozyan et al., 1987). The major Dashkasan iron skarn deposit also belongs to this metallogenic event (D in Fig. 1). Re-Os molybdenite dating yielded porphyry $\mathrm{Cu}$ ages of 145.9 Ma at Teghout and 133.3 Ma at Khar-Khar in the Gedabek district (Moritz et al., 2012). The youngest metallogenic event associated with subduction along the Somkheto-Karabagh belt includes copper, polymetallic and precious metal deposits of the Bolnisi district hosted by Late Cretaceous volcano-sedimentary rocks of the Artvin-Bolnisi volcanic arc (B in Fig. 1), and include the operating $\mathrm{Cu}$-Au-polymetallic Madneuli deposit, the precious metal Sakdrisi deposit, and the polymetallic Beqtakari prospect (Gugushvili, 2004; Migineishvili, 2005; Popkhadze et al., 2014). To the west, the Artvin-Bolnisi volcanic arc extends into the VMSporphyry-epithermal districts of the Turkish Eastern Pontides (Fig. 1; Kekelia et al., 2004; Yigit, 2009; Delibas et al., in press).

Following accretion of the South Armenian block with the Eurasian margin, ore deposit formation was associated with Eocene back-arc magmatism in the Adjara-Trialeti belt (Fig.1; e.g. Merisi, Me in Fig.1), and several important epithermal gold deposits are associated with Cenozoic magmatism of uncertain age. They occur along major tectonic zones, and include the Zod-Sotk (Kozerenko, 2004; Levitan, 2008), Amulsar (www.lydianinternational.co.ck) and Meghradzor (Amiryan and Karapetyan, 1964) deposits (Z, Am and Mg in Fig. 1). Their age, characteristics and the associated magmatism still remain to be fully studied.

The major ore deposit cluster formed during the Cenozoic following collision of the South Armenian block with Eurasia is located in the Zangezur-Ordubad region (ZO in Fig. 1), of the southernmost Lesser Caucasus (Fig. 3b), and belongs to our study area. The major ore deposits and prospects hosted by the composite Meghri and Bargushat plutons are porphyry deposits (Karamyan, 1978; Babazadeh et al., 1990), and subsidiary epithermal prospects of lesser economic interest hosted by volcanic and plutonic rocks (Amiryan, 1984; Babazadeh et al., 1990). Their main characteristics, reserves and ore grades are summarized in Table 1 . The Cenozoic porphyry deposits of the Zangezur-Ordubad region are significantly enriched in Mo with respect to the older Late Jurassic-Early Cretaceous porphyry deposits hosted by the Somkheto-Karabagh magmatic arc, such as Teghout or Gedabek ( $T$ and $G$ in Fig. 1). Therefore, deposits of the Mesozoic Somkheto-Karabagh arc qualify as porphyry $\mathrm{Cu}$ deposits, whereas the Cenozoic ones of the Zangezur-Ordubad region are classified as porphyry Cu-Mo deposits (Fig. 5; Karamyan, 1978; Babazadeh et al., 1990). Re-Os molybdenite dating reveals two main porphyry events in the Zangezur-Ordubad region (Moritz et al., 2013). The first porphyry $\mathrm{Cu}-\mathrm{Mo}$ event is associated with Eocene magmatic activity (Fig. 4), and includes the operating Agarak deposit (44.2 $\pm 0.2 \mathrm{Ma})$, and the Hankasar (43.14 $\pm 0.17 \mathrm{Ma})$, Aygedzor $(42.62 \pm 0.17 \mathrm{Ma})$ and Dastakert prospects $(40.22 \pm 0.16$ to $39.97 \pm 0.16 \mathrm{Ma})$. The second 
event is late Oligocene in age, coeval with magmatism (Fig. 4), and includes the producing world-class Kadjaran deposit $(27.2 \pm 0.1$ to $26.43 \pm 0.11 \mathrm{Ma})$, and the past producing Paragachay deposit $(26.78 \pm 0.11 \mathrm{Ma})$. According to K-Ar ages published by Bagdasaryan et al. (1969), epithermal mineralization is associated with both Eocene and Oligocene magmatic activity, at $37.5 \pm 0.5$ and $38.0 \pm 2.5 \mathrm{Ma}$ at the Tey-Lichkvaz gold prospect, and at $24 \pm 1 \mathrm{Ma}$ at the Atkis polymetallic prospect near Kadjaran (Figs $3 b$ and 4). On a world-wide comparison, the porphyry $\mathrm{Cu}-\mathrm{Mo}$ deposits of the Zangezur-Ordubad region have modest metal contents, except the undated Eocene to Oligocene Misdag deposit and the 26-27 Ma-old Kadjaran deposit (Fig. 5). The ore deposit cluster of the Zangezur-Ordubad region of southern Armenia and Nakhitchevan extends to the south into the Cenozoic metallogenic Alborz/Arasbaran and Urumieh-Dokhtar/Kerman belts of Iran (Fig. 1), where porphyry CuMo deposits and subsidiary epithermal prospects are reported, including the major Miocene Sungun deposit (Jamili et al., 2010; Aghazadeh et al., 2015; Hassanpour et al., 2015; Simmonds and Moazzen, 2015).

\section{Analytical techniques}

A total of fifty-three magmatic rock samples from the Zangezur-Ordubad region were selected for whole rock geochemical analyses. Altered and weathered surfaces were removed by a diamond circular saw. The samples were crushed by a hydraulic press and subsequently powdered to $<10 \mu \mathrm{m}$ using a mortar agate mill. Loss on ignition (LOI) was determined based on the mass difference of 2-3 grams of dried powdered rock before and after heating to 1050 C. Major and some trace elements (from $\mathrm{Nb}$ to $\mathrm{Ba}$, Table 2) were analysed, respectively, on fused lithium tetraborate glass beads and pressed pellets using a Philips PW 2400 spectrometer at the University of Lausanne, Switzerland. The $2 \sigma$ uncertainties are $<1 \%$ based on repeated measurements of the BHVO-1, NIM-N and NIM-G standards. Trace elements from Sc to U (marked by an asterisk in Table 2) were determined by laser ablation ICP-MS at the University of Lausanne on the same glass beads as used for major element analysis, using a sector-filed Element XR ICP mass spectrometer interfaced to an UP-193FX $193 \mathrm{~nm}$ excimer ablation system. The spectrometer was operated at low resolution; it was optimised for a maximum sensitivity at $\mathrm{ThO}^{+} / \mathrm{Th}^{+}$and $\mathrm{Ba}^{++} / \mathrm{Ba}^{+}$ratios of $\sim 0.10$ and $<2.9 \%$, respectively. The on-sample laser beam fluence was set at $5 \mathrm{~J} / \mathrm{cm}^{2}$ at a laser pulse repetition rate of $10 \mathrm{~Hz}$; the pit size was $100 \mu \mathrm{m}$. Helium was used as a carrier gas. Background and signal were measured during about 90 and 50 seconds, respectively. Three points were measured on each sample and the results were averaged. Calcium previously determined by XRF was used as internal standard. The NIST 612 soda-lime-silica glass standard was used as external standard to calibrate the instrument mass fractionation. Concentration values were taken from Pearce et al. (1997). The raw data were reduced using LAMTRACE (Jackson, 2008). 
Sixteen whole-rock samples were analysed for $\mathrm{Pb}, \mathrm{Sr}$ and $\mathrm{Nd}$ isotopic compositions at the University of Geneva, Switzerland following the method described by Chiaradia et al. (2011). Powdered rock samples were dissolved in closed Teflon vials for 7 days on a hot plate at $140^{\circ} \mathrm{C}$ with a mixture of $4 \mathrm{ml}$ concentrated $\mathrm{HF}$ and $1 \mathrm{ml} 15 \mathrm{M} \mathrm{HNO}$. The samples were then dried on a hot plate, and re-dissolved in $3 \mathrm{ml}$ of $14 \mathrm{M} \mathrm{HNO}_{3}$ in closed Teflon vials at $140^{\circ} \mathrm{C}$ and dried down again. Strontium, $\mathrm{Nd}$ and $\mathrm{Pb}$ separation was carried out using cascade columns with Sr-spec, TRU-spec and Ln-spec resins following a modified method after Pin et al. (1994). The analyses were carried out in static mode using a Thermo Triton thermal ionization mass spectrometer on Faraday cups. $\mathrm{Pb}$ was loaded on Re filaments using the silica gel technique. Samples and standards were measured at a pyrometer-controlled temperature of $1220^{\circ} \mathrm{C}$. Lead isotope ratios were corrected for instrumental fractionation by a factor of $0.07 \%$ per a.m.u. based on the SRM981 standard and using the standard values of Todt et al. (1996). External reproducibility of the standard ratios are $0.08 \%$ for ${ }^{206} \mathrm{~Pb} /{ }^{204} \mathrm{~Pb}, 0.11 \%$ for ${ }^{207} \mathrm{~Pb} /{ }^{204} \mathrm{~Pb}$ and $0.15 \%$ for ${ }^{208} \mathrm{~Pb} /{ }^{204} \mathrm{~Pb}$. Strontium was loaded on single Re filaments with a $\mathrm{Ta}$ oxide solution and measured at a pyrometer-controlled temperature of $1480^{\circ} \mathrm{C}$ in static mode. ${ }^{87} \mathrm{Sr} /{ }^{86} \mathrm{Sr}$ values were internally corrected for fractionation using a ${ }^{88} \mathrm{Sr} /{ }^{86} \mathrm{Sr}$ value of 8.375209 . Raw values were further corrected for external fractionation by a value of $+0.03 \%$, determined by repeated measurements of the SRM987 standard $\left({ }^{87} \mathrm{Sr} /{ }^{86} \mathrm{Sr}=0.710250\right)$. External reproducibility of the ${ }^{87} \mathrm{Sr} /{ }^{86} \mathrm{Sr}$ ratio for the SRM987 standard is $7 \mathrm{ppm}$. Neodymium was loaded on double Re filaments with $1 \mathrm{M} \mathrm{HNO}_{3}$ and measured in static mode. ${ }^{143} \mathrm{Nd} /{ }^{144} \mathrm{Nd}$ values were internally corrected for fractionation using a ${ }^{146} \mathrm{Nd} /{ }^{144} \mathrm{Nd}$ value of 0.7219 and the ${ }^{144} \mathrm{Sm}$ interference on ${ }^{144} \mathrm{Nd}$ was monitored on the mass ${ }^{147} \mathrm{Sm}$ and corrected by using a ${ }^{144} \mathrm{Sm} /{ }^{147} \mathrm{Sm}$ value of 0.206700 . External reproducibility of the JNdi-1 standard (Tanaka et al., 2000 ) is $<5 \mathrm{ppm}$. Corrections for time-integrated decay of radioactive parents to radiogenic daughters were carried out for the samples using parent and daughter element concentrations determined by LA-ICP-MS and appropriate age estimates.

Fifteen oxygen isotope analyses of whole rock powders were carried out on a Finigan MAT 253 at the University of Lausanne, Switzerland. The detailed analytical procedure is described in Jourdan et al. (2009). The laser fluorination technique was used to extract oxygen from whole rock samples (Sharp, 1992). Oxygen was analysed as $\mathrm{O}_{2}$ gas. An internal quartz standard (Lausanne Quartz: 18.1\%o V-SMOW) calibrated against NBS-28 quartz (9.64\%o VSMOW; Coplen et al., 1983) was used to monitor accuracy and reproducibility of oxygen isotope analyses. All data are reported in per mil notation (\%o). The analytical reproduction obtained by daily standard measurements of Lausanne Quartz was routinely better than $0.1 \%$.

Six samples were selected for U-Pb zircon dating, and were crushed and milled to $<350 \mu \mathrm{m}$, and then separated using a Wifley table, a Frantz magnetic separator and gravimetry using heavy liquids. Zircons from the non-magnetic fraction were selected for further treatment and 
isotopic dating. In order to minimize the effects of secondary lead loss, the zircons were treated by "chemical abrasion" prior to analysis (Mattinson, 2005) involving high temperature annealing followed by a HF partial dissolution step similar to the procedure described in Barboni et al. (2013). For each sample various morphology zircon grains were selected (short and long prismatic, preferably clean, rarely with melt inclusions or channels). No correlation was observed between morphology and age. All zircon grains were dissolved after adding $\sim 0.0052 \mathrm{~g}$ mixed EARTHTIME ${ }^{202} \mathrm{~Pb}^{205} \mathrm{~Pb}^{233} \mathrm{U}-{ }^{235} \mathrm{U}$ tracer (www.earth-time.org) in $170 \mu \mathrm{l}$ concentrated $\mathrm{HF}$ with a trace of $7 \mathrm{~N} \mathrm{HNO}_{3}$ at $206^{\circ} \mathrm{C}$ for 3 days, then evaporated and the residue re-dissolved overnight in $3 \mathrm{~N} \mathrm{HCl}$ at $206^{\circ} \mathrm{C}$. $\mathrm{Pb}$ and $\mathrm{U}$ from zircons were separated by anion exchange chromatography (Krogh, 1973) in $40 \mu 1$ micro-columns, using minimal amounts of ultra-pure $\mathrm{HCl}$ and $\mathrm{H}_{2} \mathrm{O}$, and finally dried down with $3 \mu \mathrm{l}$ of $0.02 \mathrm{~N}_{3} \mathrm{PO}_{4}$. Isotopic analyses were performed at the University of Geneva, Switzerland on a Thermo Triton thermal ionization mass spectrometer equipped with a MasCom electron multiplier. The linearity of the multiplier was calibrated using U500, SRM987, and Pb SRM982 and SRM983 solutions. Lead fractionation for all analyses was corrected offline assuming a ${ }^{202} \mathrm{~Pb} /{ }^{205} \mathrm{~Pb}$ of $0.99989 \pm 0.01 \%, 1 \sigma$. The $\mathrm{U}$ mass fractionation for the same analyses was calculated in real-time using the ${ }^{233} \mathrm{U}_{-}^{235} \mathrm{U}$ ratio of the double spike solution $(0.99464 \pm 0.01 \%$, $1 \sigma)$. Both $\mathrm{Pb}$ and $\mathrm{U}$ were loaded with a silica gel-phosphoric acid mixture on outgassed single Re-filaments. $\mathrm{Pb}$ isotope compositions were measured on the electron multiplier, while $\mathrm{U}$ (as $\mathrm{UO}_{2}$ ) isotopic measurements were made in static Faraday mode (using amplifiers equipped with $10^{12} \Omega$ resistors). Isobaric interference of ${ }^{233} \mathrm{U}^{18} \mathrm{O}^{16} \mathrm{O}$ on ${ }^{235} \mathrm{U}^{16} \mathrm{O}^{16} \mathrm{O}$ was corrected using a ${ }^{18} \mathrm{O} /{ }^{16} \mathrm{O}$ ratio of 0.00205 . All common $\mathrm{Pb}$ for the zircon analyses was attributed to procedural blank and corrected with the following isotopic composition: ${ }^{206} \mathrm{~Pb} /{ }^{204} \mathrm{~Pb}=18.30 \pm$ $0.71 \% ;{ }^{207} \mathrm{~Pb} /{ }^{204} \mathrm{~Pb}=15.47 \pm 1.03 \% ;{ }^{208} \mathrm{~Pb} /{ }^{204} \mathrm{~Pb}=37.60 \pm 0.98 \%$ (all $1 \sigma$ ). U blanks were $<0.1$ pg and do not influence the degree of discordance at the age range of the studied samples, therefore a value of $0.05 \mathrm{pg}+/-50 \%$ was used in all data reduction. Initial statistics were performed using TRIPOLI (Bowring et al., 2011), followed by data reduction and age calculation using the YourLab xls spreadsheet, all measured ratios being reduced using the algorithms of Schmitz and Schoene (2007) and Crowley et al. (2007). Generation of concordia plots and weighted means were performed with Isoplot (Ludwig, 2005). The reproducibility and accuracy of the data measured was assessed by repeated analysis of the 100Ma synthetic solution (Condon et al., 2008) and international R33 standard zircon (Black et al., 2004), which was pre-treated by chemical abrasion. Both yielded an internal reproducibility in ${ }^{206} \mathrm{~Pb} /{ }^{238} \mathrm{U}$ dates of better than $0.05 \%$. The standard zircon R33 was measured with EARTHTIME ${ }^{202} \mathrm{~Pb}_{-}{ }^{205} \mathrm{~Pb}_{-}{ }^{235} \mathrm{U}_{-}{ }^{238} \mathrm{U}$ tracer at an average ${ }^{206} \mathrm{~Pb} /{ }^{238} \mathrm{U}$ age of $419.58 \pm 0.05 \mathrm{Ma}(\mathrm{MSWD}=1.5, \mathrm{n}=22)$. All uncertainties are reported at the 2-sigma level. All data are reported with internal errors only, including counting statistics, uncertainties in mass discrimination and the common $\mathrm{Pb}$ composition. The MSWD values of weighted mean 
from all samples are within the range of acceptable values at $95 \%$ confidence level and for $n$ 1 degrees of freedom (Wendt and Carl, 1991).

\section{Results}

\subsection{Whole-rock major and trace element geochemistry}

Major and trace element compositions are listed in Table 2. For petrologic classification and diagram presentation, major oxide data were normalized to a $100 \%$ volatile-free basis. Volcanic and sub-volcanic rocks were classified according to the total alkali-silica (TAS) diagram of Le Maître (2002), which also includes the equivalent names for coarse-grained intrusive rocks according to Middlemost (1994) (Fig. 6a). Plutonic rocks were also classified based on modal mineral proportions and plotted in the QAPF diagram (Fig. 6b; Streckeisen, 1976). Thirteen out of fifty-three rock samples affected by hydrothermal alteration (see Table 2), collected within main mineralized and mining areas, and/or revealing LOI above $2.2 \mathrm{wt} \%$ were not retained for plotting and interpretation using major and trace elements known to be mobile during hydrothermal alteration (e.g. K, Na, Sr, Rb). Therefore, data trends in diagrams have petrogenetic significance, and are devoid of potential hydrothermal alteration effects.

There is a good agreement of the names of plutonic rocks when plotted both in the QAPF and TAS diagrams (Figs 6a-b), and are supported by our petrographic studies of representative samples (Fig 7; Table 3). The Eocene volcanic rocks from the Kaputjugh suite, one dike and a mafic enclave range in composition between basaltic and andesitic, and one volcanic rock sample yields a dacitic composition (DA-12-04, Table 2). The Eocene plutonic rocks vary mainly in composition between granitic and granodioritic (Fig 7; Table 3). A larger range in composition is displayed by Oligocene plutonic rocks with gabbro, monzonite, monzodiorite, quartz-monzonite, granite, syenite, quartz-syenite, and monzogabbro. Miocene rocks consist mainly of granite, granodiorite and quartz-monzonite (Fig 7; Table 3). The Pliocene volcanic rock is a dacite-trachydacite (Figs 6a-b, 7; Table 3). The diversity of Eocene to Pliocene rock types identified and analysed in this study (e.g. Fig .7; Table 3) broadly agree with the more detailed classification scheme published by Karamyan et al. (1974) and Tayan et al. (1976).

Based on the $\mathrm{K}_{2} \mathrm{O}$ vs $\mathrm{SiO}_{2}$ classification diagram, Eocene magmatic rocks of the MeghriOrdubat and Bergushat plutons have the lowest $\mathrm{K}_{2} \mathrm{O}$ contents and belong essentially to a calcalkaline to high-K calc-alkaline trend, with two outliers in the tholeiitic field (Fig. 6c). By contrast, the Oligocene samples include the most $\mathrm{K}_{2} \mathrm{O}$-enriched rocks and display high- $\mathrm{K}$ calc-alkaline and shoshonitic affinities. Except one sample, the Miocene and Pliocene rock samples fall along the high-K calc-alkaline trend (Fig. 6c). 
Harker diagrams of major elements show mostly good correlations (Figs 8a-g), which can be attributed to varying degrees of fractional crystallization as a first approximation. In contrast to major elements, Harker diagrams using selected trace elements show distinct differences among magmatic rocks of different ages (Figs 9a-h). Thorium, niobium and strontium concentrations of Eocene magmatic rocks are relatively constant despite variations in $\mathrm{SiO}_{2}$ $\mathrm{wt} \%$, in contrast Oligocene to Pliocene rock samples yield a broad positive correlation of Th concentrations, and a negative one for $\mathrm{Sr}$ with respect to $\mathrm{SiO}_{2}$ (Figs 9a-c). The Eocene magmatic rocks have in general lower concentrations of $\mathrm{Th}, \mathrm{Nb}$ and $\mathrm{Sr}$ compared to Oligocene, Miocene and Pliocene magmatic rocks for similar $\mathrm{SiO}_{2}$ contents (Figs 9a-c), except two Eocene intrusive rocks samples having an adakitic-like composition (see below) according to Figure 9c, with distinctly higher Sr concentration above $600 \mathrm{ppm}$. Yttrium and ytterbium display the highest concentrations in Eocene and Oligocene rocks, and the lowest concentrations in Miocene and Pliocene rock samples (Figs 9d-e). Zirconium contents increase with more differentiated rocks, but with a distinct scatter for samples with $\mathrm{SiO}_{2}$ above $60 \mathrm{wt} \%$ regardless of their age, and distinct elevated $\mathrm{Zr}$ concentrations exceeding 200 ppm for some Oligocene shoshonitic samples (Fig. 9f). Nickel and chromium concentrations are predominantly below $10 \mathrm{ppm}$ in most samples (Figs $9 \mathrm{~g}-\mathrm{h}$ ). Notable exceptions are five Miocene and one Pliocene rock samples displaying elevated $\mathrm{Ni}$ and $\mathrm{Cr}$ concentrations above, respectively, 30 and 40 ppm for $\mathrm{SiO}_{2}$ contents between 65 and $70 \mathrm{wt} \%$ (Figs 9g-h), which are clearly inconsistent with typical fractionation trends in magmatic suites.

In primitive, mantle-normalized extended trace element spider diagrams, all rocks of this study display similar patterns, with negative $\mathrm{Nb}$-Ta anomalies relative to LILE, and variably pronounced, negative Ti anomalies (Figs 10a-c). The marked, negative $\mathrm{P}$ anomalies reveal the potential role of apatite fractionation in the Eocene to Pliocene magmatic rocks (Figs 10a-c). A significant difference is that most Oligocene, and all Mio-Pliocene rock samples are typically enriched in the most incompatible elements with respect to the Eocene samples (Cs to $\mathrm{Nd}$, left hand-side of spider diagrams, Figs 10a-c). Two samples among the Eocene magmatic rocks have distinctly higher $\mathrm{Th}, \mathrm{U}, \mathrm{Zr}$ and $\mathrm{Hf}$, and lower $\mathrm{Ba}$ and $\mathrm{Rb}$ concentrations in contrast to rocks of the same age (Fig. 10a; samples AG-10-03 and AG-10-06A in Table 2).

Chondrite-normalized REE diagrams show that most of the Oligocene magmatic rocks, and all of the Miocene and Pliocene rock samples are enriched in LREE with respect to the Eocene ones, and that Miocene and Pliocene rocks are depleted in HREE with respect to Eocene and Oligocene samples (Figs 11a-c). The progressively more intense LREE and MREE to HREE fractionation from the oldest to youngest rocks in the Meghri pluton is documented, respectively, by progressively higher $(\mathrm{La} / \mathrm{Yb})_{\mathrm{n}}$ and $(\mathrm{Dy} / \mathrm{Yb})_{\mathrm{n}}$ ratios (Fig. 12a), with the exception of the more mafic Eocene rocks, which display flatter, less fractionated REE patterns when compared to the more felsic Eocene rocks (Fig. 11a). 
According to the $\mathrm{Sr} / \mathrm{Y}$ vs $\mathrm{Y}, \mathrm{La} / \mathrm{Yb}$ vs $\mathrm{Yb}, \mathrm{Sr} / \mathrm{Y}$ vs $\mathrm{SiO}_{2}$ and $\mathrm{La} / \mathrm{Yb}$ vs $\mathrm{SiO}_{2}$ discrimination plots (Fig. 13), all analysed Miocene and Pliocene, and a few Oligocene magmatic rocks qualify as adakites, based on the classification criteria summarized by Martin et al. (2005). Eocene magmatic rocks typically have low $\mathrm{Sr} / \mathrm{Y}$ and $\mathrm{La} / \mathrm{Yb}$ ratios, and fall in the normal arc andesite-dacite-rhyolite domain (Fig. 13), except two intrusions with high adakitic-like $\mathrm{Sr} / \mathrm{Y}$ ratios (Figs 13a, c), but non-adakitic $\mathrm{La} / \mathrm{Yb}$ vs $\mathrm{Yb}$ and $\mathrm{La} / \mathrm{Yb}$ vs $\mathrm{SiO}_{2}$ relationships (Figs 13b, d). The $\mathrm{MgO}$ vs $\mathrm{SiO}_{2}$ diagram (Fig. $8 \mathrm{~g}$ ) indicates that the adakites are of the high-silica type according to the classification scheme of Martin et al. (2005).

\section{2. $\mathrm{Sr}, \mathrm{Nd}, \mathrm{Pb}$, and $\mathrm{O}$ isotope geochemistry}

Isotopic compositions of selected samples are listed in Table 4. All samples from the MeghriOrdubad and Bargushat plutons have primitive, mantle-dominated $\mathrm{Sr}$ and $\mathrm{Nd}$ isotopic compositions (Fig. 14a). There is a typical negative correlation of $\mathrm{Sr}$ and $\mathrm{Nd}$ isotopic compositions of Eocene and Oligocene magmatic rocks from the Meghri-Ordubad and Bargushat plutons (Fig. 14b). Except one sample published by Mederer et al. (2013), the Eocene magmatic rocks yield the highest ${ }^{87} \mathrm{Sr} /{ }^{86} \mathrm{Sr}$ ratios $(0.704206-0.704629)$ and the lowest ${ }^{143} \mathrm{Nd} /{ }^{144} \mathrm{Nd}$ ratios $(0.512740-0.512785)$, and the three analysed Oligocene samples have lower ${ }^{87} \mathrm{Sr} /{ }^{86} \mathrm{Sr}$ ratios $(0.703926-0.704027)$ and higher ${ }^{143} \mathrm{Nd} /{ }^{144} \mathrm{Nd}$ ratios $(0.512774-$ 0.512817). By contrast, $\mathrm{Sr}$ and $\mathrm{Nd}$ isotopic compositions of the Miocene and Pliocene magmatic rocks define a positive correlation, discordant with respect to the trend revealed by the Eocene and Oligocene rocks, with ${ }^{87} \mathrm{Sr} /{ }^{86} \mathrm{Sr}$ ratios between 0.704037 and 0.704354 and ${ }^{143} \mathrm{Nd} /{ }^{144} \mathrm{Nd}$ ratios between 0.512799 and 0.512845 (Fig. 14b, Table 4). Strontium and Nd isotopic compositions of the magmatic rocks of the Meghri-Ordubad and Bargushat plutons correlate with $\mathrm{Sr}$ and $\mathrm{Nd}$ concentrations. The most radiogenic Sr compositions correlate with the highest $1 / \mathrm{Sr}$ ratios, i.e. the lowest $\mathrm{Sr}$ concentrations, which characterise the Eocene magmatic rocks (Fig. 15a). By contrast, the least radiogenic $\mathrm{Nd}$ values correspond to the highest $1 / \mathrm{Nd}$ ratios, i.e. the lowest $\mathrm{Nd}$ concentrations, which are also characteristic of the Eocene magmatic rocks. Based on the ${ }^{143} \mathrm{Nd} /{ }^{144} \mathrm{Nd}$ vs $1 / \mathrm{Nd}$ diagram, the Plio-Miocene magmatic rocks are distinct from the Oligocene ones, and are shifted towards higher $1 / \mathrm{Nd}$ ratios and more radiogenic $\mathrm{Nd}$ compositions (Fig. 15b).

There is a general, consistent trend of increasing ${ }^{206} \mathrm{~Pb} /{ }^{204} \mathrm{~Pb}$ (from 18.44 to 19.09) and ${ }^{208} \mathrm{~Pb} /{ }^{204} \mathrm{~Pb}$ ratios (from 38.43 to 39.13 ) from the Eocene to the Mio-Pliocene magmatic rocks of the Meghri-Ordubad and Bargushat plutons, whereas the ${ }^{207} \mathrm{~Pb} /{ }^{204} \mathrm{~Pb}$ ratios remain broadly constant between 15.52 and 15.60 (Fig. 16, Table 3). The samples from the Meghri-Ordubad and Bargushat plutons plot below the orogenic $\mathrm{Pb}$ isotope evolutionary curve of Zartman and Doe (1981) in the ${ }^{207} \mathrm{~Pb} /{ }^{204} \mathrm{~Pb}$ vs ${ }^{206} \mathrm{~Pb} /{ }^{204} \mathrm{~Pb}$ plot (Fig. 16a), revealing a mantle-dominated 
reservoir, consistent with the $\mathrm{Sr}$ and $\mathrm{Nd}$ isotope data. In the ${ }^{208} \mathrm{~Pb} /{ }^{204} \mathrm{~Pb}$ vs ${ }^{206} \mathrm{~Pb} /{ }^{204} \mathrm{~Pb}$ plot (Fig. 16b), the samples from the Meghri-Ordubad and Bargushat plutons fall on a trend that is clearly discordant with respect to the $\mathrm{Pb}$ isotope evolutionary curves of Zartman and Doe (1981), revealing an evolution from a more thorogenic composition during the Eocene to a more upper crustal-dominated composition during the Mio-Pliocene (Fig. 16b).

The oxygen isotopic compositions of most of the Eocene to Pliocene magmatic rocks from the Meghri-Ordubad and Bargushat plutons fall in a +5.5 to $+8.3 \%$ range, with the exception of two Eocene volcanic rocks samples at +3.7 and $+3.8 \%$ (Fig. 17).

\subsection{U-Pb ID-TIMS dating}

All U-Pb data are presented in Table 5. Sample AG-10-06A is a granodiorite sampled in the area of Agarak (Fig 3b). Six zircon grains were analysed. All of them are concordant within analytical error but show a scater between $48.99 \pm 0.07$ and $49.41 \pm 0.09 \mathrm{Ma}$ in ${ }^{206} \mathrm{~Pb} /{ }^{238} \mathrm{U}$ dates (Fig. 18a; Table 5). Since the chemical abrasion technique is eliminating the lead loss effect extremely efficiently, we assume that the observed scater is a result of minor inherited lead component or reflects a real age variation of zircon crystalisation. Therefore, we interpret the youngest age of $48.99 \pm 0.07 \mathrm{Ma}$ as the best proximate of the end of zircon crystalisation in this granodiorite. Sample AG-10-07 is a granite sampled in the area of Agarak (Fig. 3b). Six zircon grains were analysed. All of them are analyticaly concordant yielding a cluster with a weighted mean age of ${ }^{206} \mathrm{~Pb} /{ }^{238} \mathrm{U}$ age of $44.03 \pm 0.02 \mathrm{Ma}$, MSWD=0.76 (Fig. 18b; Table 5). Sample KJ-12-07 is a gabbro collected on the Meghri ridge (Fig. 3b). Six zircon grains were analysed. The data are concordant within analytical error and yield a weighted mean ${ }^{206} \mathrm{~Pb} /{ }^{238} \mathrm{U}$ age of $33.49 \pm 0.02 \mathrm{Ma}, \mathrm{MSWD}=2.4,95 \%$ confidence level (Fig. 18c; Table 5). Sample KJ-10-02 is a monzonite collected at Atkis in the Kadjaran area (Fig. 3b). Five zircon grains were analysed. The data are concordant within analytical error and yield a weighted mean ${ }^{206} \mathrm{~Pb} /{ }^{238} \mathrm{U}$ age of $31.82 \pm 0.02 \mathrm{Ma}, \mathrm{MSWD}=1.7$ (Fig. 18d; Table 5). Sample KJ-12-11A is an altered porphyritic granodioritic dike collected in the Kadjaran open pit (Fig. 3b). Six zircon grains were analysed, scatering between ${ }^{206} \mathrm{~Pb} /{ }^{238} \mathrm{U}$ dates of $22.46 \pm 0.02$ and $31.07 \pm$ $0.04 \mathrm{Ma}$. The youngest date of $22.46 \pm 0.02 \mathrm{Ma}$ is considered to be the best proximate of the end of zircon cristallisation (Fig. 18e; Table 5). Sample LI-10-03 is a granite sample in the Lichk area, south of Kadjaran (Fig. 3b). Nine zircon grains were analysed. Four of them are clustering and yield a weighted mean ${ }^{206} \mathrm{~Pb} /{ }^{238} \mathrm{U}$ age of $22.22 \pm 0.01 \mathrm{Ma}, \mathrm{MSWD}=0.66$. The remaining five grains are older and scater up to $22.56 \pm 0.02$ Ma. (Fig. 18f; Table 5). 


\section{Discussion}

\subsection{Protracted Eocene to Pliocene magmatism in the Zangezur-Ordubad region}

The U-Pb ID-TIMS ages obtained in this study confirm the pulsed magmatic activity from the Eocene to the Miocene in the composite Meghri-Ordubad and Bargushat plutons (Fig. 4). The Eocene calc-alkaline to high-K calc-alkaline intrusive rocks dated in this study (AG-10-06A granodiorite and AG-10-07 granite) agree with the $\mathrm{Rb}-\mathrm{Sr}$ isochron ages obtained previously by Melkonyan et al. $(2008,2010)$. In addition, the oldest age of $48.99 \pm 0.07 \mathrm{Ma}$ of sample AG-10-06A (Fig. 18) is close to the age of one gabbro sample from the Kapan block (immediately east of the Meghri-Ordubad pluton, Fig. 3b) dated by Mederer et al. (2013) at $50.82 \pm 0.51 \mathrm{Ma}$. The similar early Cenozoic ages of magmatic rocks of both the MeghriOrdubad pluton and the Kapan zone (Fig. 3a) indicate that the later was already accreted with the South Armenian block during the Eocene, and support the geodynamic model of Rolland et al. (2009a,b) and Sosson et al. (2010) for the Lesser Caucasus.

The two Oligocene magmatic rocks dated in our study (KJ-12-07 gabbro and KJ-10-02 monzonite) are also consistent with previous $\mathrm{Rb}$-Sr isochron dating (Melkonyan et al., 2008, 2010). Our new ages show that this high-K calc-alcaline to shoshonitic magmatic event started close to the Eocene-Oligocene transition (Fig. 4). In addition, the $33.49 \pm 0.02 \mathrm{Ma}$ age obtained for one gabbro sample (KJ-12-07, Fig. 18) reveals that gabbroic rocks were also emplaced during the Oligocene, and not only during the Eocene event, as concluded before by by Ghukasyan (1966) based on whole-rock K-Ar dating at 41.4 $\pm 3.5 \mathrm{Ma}$. Finally, there is an excellent overlap of our new TIMS U-Pb Miocene ages for the adakitic magmatism (KJ-1211A porphyritic granodiorite dike and LI-10-03 granite) and the $\mathrm{Rb}-\mathrm{Sr}$ isochron ages obtained by Melkonyan et al. (2008, 2010; Fig. 4).

\subsection{Eocene to Pliocene subduction-like and mantle-dominated magmas in the Zangezur- Ordubad region}

The similar, primitive mantle-normalized spider diagrams of the Eocene to Pliocene magmatic rocks, with negative $\mathrm{Nb}$, Ta and Ti anomalies (Figs 10a-c), are consistent with a subduction-related signature during the entire Cenozoic evolution of the Meghri-Ordubad and Bargushat plutons, with the magmas generally evolving from a normal calc-alkaline to high-K calc-alklaine arc composition during the Eocene through an early Oligocene shoshonitic to a Mio-Pliocene adakitic-like composition (Figs 6c, 13a-d). Strontium and neodymium isotopic compositions reveal a mantle-dominated magmatism, with the mantle component becoming progressively more predominant from the Eocene to the Oligocene and Plio-Miocene (Figs 14 and 15). The mantle-dominated nature of the magmas that produced the Meghri-Ordubad and 
Bargushat plutons is also supported by $\mathrm{Pb}$ isotope data, In the ${ }^{207} \mathrm{~Pb} /{ }^{204} \mathrm{~Pb}$ vs ${ }^{206} \mathrm{~Pb} /{ }^{204} \mathrm{~Pb}$ plot (Fig. 16a), samples from the Meghri-Ordubad and Bargushat plutons plot below the orogenic $\mathrm{Pb}$ isotope evolutionary curve of Zartman and Doe (1981), towards a mantle-dominated reservoir.

\subsection{Magmatic fractionation processes and Eocene to Pliocene crustal thickness evolution}

Negative correlation between $\mathrm{Dy} / \mathrm{Yb}$ ratios and increasing $\mathrm{SiO}_{2}$ contents (Fig. 19a) reflects amphibole/clinopyroxene fractionation (Davidson et al., 2007) in all Eocene and Oligocene magmatic rocks of the Meghri-Ordubad and Bargushat plutons. The diagonal trend with a negative slope of most Eocene and Oligocene samples in the $\mathrm{CaO} / \mathrm{Al}_{2} \mathrm{O}_{3}$ vs $\mathrm{FeO}_{\text {tot }} / \mathrm{MgO}$ diagram (Fig. 8h) also supports a differentiation trend dominated by amphibole, possibly together with pyroxene. This interpretation is also consistent with the U-shaped REE patterns of many samples, especially the Plio-Miocene ones (Fig. 11c), since amphibole preferentially incorporates middle REE (Davidson et al., 2007; Chiaradia, 2009; Richards, 2011).

The slight to pronounced negative Eu anomaly of most Eocene and Oligocene magmatic rocks from the Meghri-Ordubad and Bargushat plutons, and the negative $\mathrm{Eu} / \mathrm{Eu}^{*}$ vs $\mathrm{SiO}_{2}$ correlation of the Eocene rock samples is attributed to plagioclase fractionation during their formation (Fig. 12b). With the exception of the adakitic Oligocene rocks, the negative correlation of the $\mathrm{Sr} / \mathrm{Y}$ ratio against increasing $\mathrm{SiO}_{2}$ concentrations of the Oligocene rocks (Fig. 13c) also reflects plagioclase crystallization during fractionation, as this process depletes $\mathrm{Sr}$ in melts, leading to typically low $\mathrm{Sr} / \mathrm{Y}$ ratios of normal arc magmas (Fig. 13a).

Pliocene and Miocene magmatic rocks reveal only minimal to positive Eu anomalies, which is attributed to a suppression of plagioclase fractionation, as a consequence of high magmatic water contents, high magmatic oxidation state, plagioclase accumulation in the rock or fractionation of hornblende (Frey et al., 1978; Hanson, 1980; Green and Pearson, 1985). The positive correlation of $\mathrm{Sr} / \mathrm{Y}$ ratios and $\mathrm{SiO}_{2}$ concentrations of the Pliocene and Miocene rocks is consistent with amphibole fractionation (Fig. 13c), which confers to these rocks their typical adakitic composition (Figs 13a-d). A group of Oligocene rocks falls at the lower endmember of the adakitic trend in Figures $13 \mathrm{c}$-d, indicating that the onset of Neogene adakitic evolution started during the Oligocene and continued during the Plio-Miocene.

A few Eocene and Oligocene magmatic rocks have $\mathrm{Eu} / \mathrm{Eu}^{*}$ ratios that deviate from the general trend described above. Two younger (44 Ma-old), more evolved Eocene samples, which diplay adakitic-like compositions according to their elevated $\mathrm{Sr} / \mathrm{Y}$ ratios (Figs. 13a-c), have only minimal to no Eu anomalies (Fig. 12b), and two mafic Eocene rock samples from the Kapan block have positive Eu anomalies (Mederer et al., 2013). The distinct elevated 
$\mathrm{Eu} / \mathrm{Eu}^{*}$ ratios of some Eocene mafic rocks emplaced in the Kapan block (Fig. 3a; Mederer et al., 2013), possibly reflects distinct differences in crustal thickness or variations of physicochemical conditions during Eocene magma generation in the two tectonic zones.

In mafic magmas, amphibole is typically stable at about $0.8 \mathrm{GPa}(\sim 30-35 \mathrm{~km})$, garnet only crystallizes at pressures generally greater than $1.2 \mathrm{GPa}(\sim 45 \mathrm{~km})$, and plagioclase is typically suppressed at high pressures above about 1.0 GPa (Rapp and Watson, 1995; Müntener et al., 2001; Alonso-Perez et al., 2009; Maksimov, 2009). The depths stated in brackets are rough approximations, since mineral breakdown pressures are a function of bulk composition, water concentration and temperature. In the Zangezur-Ordubad region, the Eocene and high-K calcalkaline early Oligocene rocks are characterised by combined amphibole and plagioclase fractionation, which indicates that the parental melts underwent low-pressure magma differentiation, at approximately $0.8-1.0 \mathrm{GPa}$. By contrast, amphibole fractionation in the absence of plagioclase and garnet fractionation is characteristic of the adakitic Oligocene, Miocene and Pliocene magmatic rocks, and is evidence for high-pressure magma fractional crystallization at approximately 1.0-1.2 GPa during the more recent magmatic evolution. The shoshonitic Oligocene magmatic rocks display highly variable $\mathrm{Eu}$ anomalies for a narrow range of $\mathrm{SiO}_{2}$ contents (Fig. 13b), therefore revealing the full spectrum of plagioclase behaviour, from plagioclase fractionation to its suppression. This may reflect a transitory state of instability, with abrupt changes in time and/or space during the early Oligocene (at about $32 \mathrm{Ma})$ of crustal depth and/or physico-chemical conditions governing plagioclase fractionation/precipitation processes when shoshonitic magmas were generated.

The Zangezur-Ordubad magmatic rocks reveal a broad trend of decreasing Y concentrations, and increasing $\mathrm{Sr} / \mathrm{Y}$ and $\mathrm{Sm} / \mathrm{Yb}$ ratios as the rocks become younger (Figs 19b-d), which is also consistent with progressive Cenozoic crustal thickening or increasing pressure of magma differentiation (e.g. Hildreth and Moorbath, 1988; Tulloch and Kimbrough, 2003; Bachmann et al., 2005). The $\mathrm{Sm} / \mathrm{Yb}$ ratios remain moderate, below a value of 5 to 6 (Fig. 19b), which can be considered as a rough threshold diagnostic for the on-set of garnet fractionation in arc magmas (Kay and Mpodozis, 2001; Haschke et al., 2006; Shafiei et al., 2009). The apparent absence of garnet during Cenozoic magma evolution is consistent with the reduced crustal thickness estimate of $42-44 \mathrm{~km}$ for the southernmost Lesser Caucasus documented by geophysical data (see Fig. 5 in Gök et al., 2011). Increasing Y concentrations (Fig. 19d), and to a lesser extent flattening of the $\mathrm{Sr} / \mathrm{Y}$ ratio evolution (Fig. 19c), during early Oligocene magmatism, including shoshonitic magmas, may reflect a transitory state of shallower pressure magma differentiation and thinning/extension of the crust at 31.8-33.5 Ma. 


\subsection{Evolution from Eocene normal arc, calc-alkaline magmatism to Mio-Pliocene adakitic magmatism, and melting of sub-continental metasomatised lithospheric mantle}

The spider diagrams and $\mathrm{Sr}$ and $\mathrm{Nd}$ isotope data reveal that the magmas, which produced the composite Meghri-Ordubad and Bargushat plutons were tapped from the same source from the Eocene to the Pliocene (Figs 10 and 14). However, characteristic trace element data trends vary from the Eocene through Oligocene to Plio-Miocene rocks. They record progressive compositional modification of a subduction-related environment during the Cenozoic. The oblique trends from Eocene magmatic rocks to Oligocene and Mio-Pliocene rocks in the ${ }^{87} \mathrm{Sr} /{ }^{86} \mathrm{Sr}$ vs. $1 / \mathrm{Sr}$ and ${ }^{143} \mathrm{Nd} /{ }^{144} \mathrm{Nd}$ vs. $1 / \mathrm{Nd}$ reflects progressively higher mantle input into the source of the magmatic rocks (Fig. 15). The HREE-depleted patterns of the Mio-Pliocene rocks with respect to Oligocene and Eocene samples also indicate that the mantle source became more depleted with time (Fig. 11).

The normal-arc, calc-alkaline to high-K calc-alcaline Eocene and Oligocene magmatic rocks display a small variation of $\mathrm{Nb} / \mathrm{Y}$ ratios for a wide range of $\mathrm{Ba}$ concentrations, whereas the shoshonitic Oligocene and the adakitic Oligocene, Miocene and Pliocene rocks cover a wider range of $\mathrm{Nb} / \mathrm{Y}$ ratios for a small range of $\mathrm{Ba}$ concentrations (Fig. 20a). The variable $\mathrm{Ba}$ contents vs. narrow $\mathrm{Nb} / \mathrm{Y}$ ratios trend displayed by the normal arc Eocene to Oligocene magmatic rocks reflects fluid-related enrichment as a consequence of dehydration of the subducted slab, whereas the trend of narrow $\mathrm{Ba}$ contents vs. wide $\mathrm{Nb} / \mathrm{Y}$ ratios of the shoshonitic to adakitic Oligocene to Pliocene magmatic rocks can be attributed to mantlederived melt enrichments (Kepezhinskas et al., 1997). The dominating subducted slab-derived fluid component during Eocene magmatism is also documented by the horizontal trend of $\mathrm{Ba} / \mathrm{La}$ ratios for constant $\mathrm{Th} / \mathrm{Yb}$ ratios, whereas the adakitic Oligocene and Mio-Pliocene rocks reveal slab-derived enrichment, with the remaining Oligocene rocks occupying intermediate compositions between the two extremes (Fig. 20b). In brief, the trace element data document progressive compositional modification with time of the source of the MeghriOrdubad and Bargushat magmatic rocks, with dominantly fluid-mobile components during the Eocene and more mantle melt-enriched and metasomatic components during the Neogene.

In Figure $20 \mathrm{~b}$, the elevated $\mathrm{Th} / \mathrm{Yb}$ ratios of the Mio-Pliocene and the majority of the Oligocene magmatic rocks (including the adakitic ones) with respect to the Eocene magmatic rocks is consistent with metasomatism of the mantle source by subducted sediments (e.g. Planck, 2005; Hermann and Rubatto, 2009; Behn et al., 2011). All Mio-Pliocene rock samples, and most Oligocene samples, in particular the adakitic ones, have marked enrichment in the most incompatible elements (left hand-side of spider diagrams from $\mathrm{Cs}$ to $\mathrm{Nd}$, Figs 10a-c) and LREE-enrichments (Fig. 11) with respect to the Eocene rocks, documenting a mantle source that became progressively enriched, and metasomatised by subducted sediments. Increasing ${ }^{206} \mathrm{~Pb} /{ }^{204} \mathrm{~Pb}$ ratios of the Cenozoic magmatic rocks also correlate with increasing $\mathrm{Th} / \mathrm{Nb}$ ratios 
(Fig. 20c), and support the increasing sedimentary component in the magmas that sourced the Mio-Pliocene intrusions. Metasomatism of the mantle source by a sedimentary component also explains the distinct positive correlation of ${ }^{87} \mathrm{Sr} /{ }^{86} \mathrm{Sr}$ and ${ }^{143} \mathrm{Nd} /{ }^{144} \mathrm{Nd}$ ratios of the Miocene and Pliocene magmatic rocks, which is discordant with respect to the general trend revealed by Eocene and Oligocene rocks (Fig. 14b). The distinct increase of ${ }^{87} \mathrm{Sr} /{ }^{86} \mathrm{Sr}$ ratios with slightly increasing $1 / \mathrm{Sr}$ ratios, and concomitant increase of ${ }^{143} \mathrm{Nd} /{ }^{144} \mathrm{Nd}$ and $1 / \mathrm{Nd}$ ratios from Oligocene to Mio-Pliocene samples reflects metasomatism of a mantle source by addition of a sedimentary ${ }^{87} \mathrm{Sr}$-enriched component (Fig. 15). The distinct shoshonitic composition of some Oligocene magmatic rocks (Fig. 6c) is further support for a mantle source compositionally modified by subducted sediments (e.g. Feldstein and Lange, 1999; Wang et al., 2006, 2014).

The $\delta^{18} \mathrm{O}$ values of most whole-rock samples from the Meghri-Ordubad and Bargushat plutons range from +5.5 to $+8.3 \%$ (V-SMOW). The lowest value at $+5.5 \%$ (V-SMOW) is consistent with a typical mantle value (Eiler, 1991; Mattey et al., 1994; Fig. 17). The $\delta^{18} \mathrm{O}$ values of the Oligocene, Miocene and Pliocene whole-rock samples display a positive correlation when plotted against $\mathrm{Th} / \mathrm{Nb}$ ratios (Fig. 17). This suggests that elevated $\delta^{18} \mathrm{O}$ values of the adakitic rocks also reflect a sedimentary component added to the mantle source during Neogene evolution. Indeed, the high $\delta^{18} \mathrm{O}$ values between +7 and $+9 \%$ (V-SMOW) overlap with those of adakites from other parts of the world, containing variable amounts of partial melts of subducted sediments or crustal contaminants derived from an over-riding plate (Bindeman et al., 2005). Two Eocene rock samples have $\delta^{18} \mathrm{O}$ values of +3.68 and $+3.80 \%$ (V-SMOW), below typical mantle values of $+5.5 \%$ (V-SMOW) (Fig. 17). One sample (KJ10-03, Table 4) is a mafic volcanic rock from the Kadjaran area and belongs to the Eocene Kaputjugh suite, and the second sample comes from an Eocene mafic dike (AG-10-04, Table 4) at Agarak (Fig. 3c). Such anomalous low $\delta^{18} \mathrm{O}$ values can be attributed to the presence of meteoric water in magmatic environments, which could have been introduced by melting of hydrothermally altered volcanic rocks (e.g. Watts et al., 2011; Simakin and Bindeman, 2012).

\subsection{Magmatic, metallogenic and geodynamic evolution of the Zangezur-Ordubad region}

The available radiometric age data allow us to subdivide the magmatic and metallogenic evolution of the Zangezur-Ordubad region into an Eocene and an Oligo-Miocene stage, which fit well with the regional geodynamic evolution of the Tethyan belt (Fig. 4). The Eocene normal arc, calc-alkaline to high-K calc-alkaline magmatism coincided with extensive magmatic activity in Iran attributed to Neotethys subduction (Fig. 4), and it resulted in the first metallogenic event with the emplacement of small tonnage porphyry $\mathrm{Cu}$-Mo deposits in the Zangezur-Ordubad region (Fig. 21a). It is during the Eocene subduction event that the 
mantle wedge was metasomatised by subducted sediments, and that the crust was progressively thickened, as evidenced by $\mathrm{Sr} / \mathrm{Y}$ and $\mathrm{Y}$ data (Figs 19c-d).

The subsequent Oligocene and Miocene magmatic and porphyry $\mathrm{Cu}-\mathrm{Mo}$ event coincided with the 40 to 25 Ma-old Arabian-Eurasian collision to post-collision tectonics in the CaucasianZagros region (Fig. 4; e.g. Vincent et al., 2005; Allen and Armstrong, 2008; Agard et al. 2011; Ballato et al., 2011; Verdel et al., 2011, McQuarrie and van Hinsberger, 2013). In the Lesser Caucasus, Alborz and Talysh ranges, collision tectonics was associated with strong deformation along the accreted terranes as documented by basin inversion, transpression and shortening after the late Eocene (e.g. Brunet et al., 2003; Vincent et al., 2005; Sosson et al., 2010). In general, collision tectonics provides an adequate environment for continental delamination and asthenospheric upwelling (e.g. Bird, 1979; Meissner and Mooner, 1998). In transpressional tectonic regimes, translithospheric faults are favourable channels for asthenospheric upwelling (e.g. Zheng et al. 2008), accompanied by increased heat flow, and localised decompression melting of thickened juvenile lower crust and metasomatised lithospheric mantle, typically resulting in high-K calc-alkaline, shoshonitic and/or adakitic magmatism (e.g. Wang et al., 2006; Hou et al. 2011; Lu et al., 2013). We propose a similar interpretation for the collision to post-collision evolution of the Zangezur-Ordubad region.

The Zangezur-Ordubad region hosting the composite Meghri-Ordubad and Bargushat plutons is bordered by the Khustup-Giratakh and Ordubad-Salvard dextral strike-slip faults (Fig. 3b), which are local segments of major regional faults, which can be traced along the entire Lesser Caucasus up to northern Armenia, and which were active at least since the Eocene (Aslanyan, 1958; Tayan et al., 1976). This long-lived fault system at the contact between the Kapan and the South Armenian blocks (Fig. 3) certainly provided the adequate zone of translithospheric weakness for repeated magma ascent from a deep source (Fig. 21), and explains the longlasting Eocene to Pliocene stationary magmatic and metallogenic activity in the southernmost Lesser Caucasus.

The radiogenic isotope data indicate a more important mantle input during Neogene magmatism in comparison to the Eocene (Fig. 14b), which supports asthenospheric mantle upwelling and increased heat flow in the Zangezur-Ordubad region, and explains localised decompression melting of juvenile lower crust and lithospheric mantle (Figs 21b-c). Our trace element data also reveal that it was an increasingly higher metasomatised lithospheric mantle component, which was involved in Oligocene to Pliocene magmatim (Fig. 21b). Conceição and Green (2004) demonstrated that decompression is the most favourable mechanism for melting a metasomatised mantle source by asthenospheric upwelling and for producing shoshonitic magmatism. Therefore, we conclude that the early Oligocene high-K calc-alkaline and shoshonitic magmatism was the result of such decompression melting affecting metasomatised lithospheric mantle at depth along the Ordubad-Savard and Khustup-Giratakh 
fault system, followed by storage and differentiation in a low-pressure crustal environment (Fig. 21b). Contemporaneous Cenozoic uplift of the Zangezur block during emplacement of the Meghri-Ordubad and Bargushat plutons (Fig. 3b), reported by Tayan et al. (1976), also supports our interpretation of continental delamination and asthenospheric upwelling. Indeed, regional uplift is a typical isostatic response to the thinking of subcontinental lithospheric mantle and replacement by hotter asthenosphere (e.g. Bird, 1979; Meissner and Mooner, 1998).

In comparison to the early Oligocene high-K calc-alkaline to shoshonitic magmatism, the younger Oligocene to Mio-Pliocene adakitic magmatism originated from a more depleted and more intensely metasomatised lithospheric mantle, and from magmas that underwent fractional crystallization at deeper levels in the crust, as suggested by our trace element data (Figs 19b-d), possibly during continuous compression. In addition, several adakitic Miocene magmatic rocks and the Pliocene sample have high $\mathrm{Ni}$ and $\mathrm{Cr}$ concentrations above, respectively, 30 and 40 ppm for similar $\mathrm{SiO}_{2}$ contents between 65 and $70 \mathrm{wt} \%$ (Figs 9g-h). These samples also have high Mg numbers at about 55, falling close or within the field of experimental hybrid melts (Fig. 20d). This suggests that some of the Mio-Pliocene adakitic melts interacted and partly equilibrated with lithospheric mantle through which they ascended (e.g. Kelemen et al., 2003; Liu et al., 2010). It is unlikely that the source was mantle metasomatised by adakitic slab melts (e.g. Rapp et al., 1999; Castro et al., 2013), because it would have required slab melting in the garnet stability field, for which there is no evidence based on magmatic rock data of this study. More realistic explanations (Fig. 21c), consistent with the chemical characteristics of the Mio-Pliocene adakitic rocks, are either partial melting of a thickened juvenile lower crust intruded by diapirs of hot metasomatised and depleted lithospheric mantle (e.g. Wang et al., 2006), or partial foundering and melting of thickened lower crust in the underlying metasomatised lithospheric mantle (e.g. Hou et al., 2011).

The Re-Os molybdenite and U-Pb zircon TIMS age data indicate that Oligocene porphyry $\mathrm{Cu}-$ Mo ore formation, including the giant Kadjaran deposit at 26-27 Ma, took place during collision to post-collision tectonic evolution of the Zangezur-Ordubad region, as early Oligocene high-K calc-alkaline and shoshonitic magmatism evolved to late Oligocene and Mio-Pliocene adakitic magmatism (Figs 4, 21b-c). Further studies are under way to clarify the exact temporal relationship of the Oligocene porphyry $\mathrm{Cu}-\mathrm{Mo}$ event with either the early shoshonitic or the younger adakitic magmatic events, or alternatively during the transition from one to the other. 


\subsection{Relationships between the magmatic-geodynamic evolution and metal endowment of porphyry deposits in the Zangezur-Ordubad region}

Porphyry $\mathrm{Cu}-\mathrm{Mo}$ deposits are typically associated with calc-alkaline magmatic subductionrelated arc settings (eg. Sinclair, 2007; Richards, 2015). By contrast, several studies have pointed out that porphyry $\mathrm{Cu}-\mathrm{Au}$ deposits would be generally expected in collision to postcollision settings characterized by alkaline magmatism (e.g. Wang et al., 2006; Richards, 2009). The Eocene Agarak and Aygedzor porphyry deposits have Au grades, respectively, of 0.025 and $0.05 \mathrm{~g} / \mathrm{t}$ (Table 1; Fig. 5c), and Au grades vary between 0.02 to $1 \mathrm{~g} / \mathrm{t}$ for the Oligocene Lichk, Kadjaran and Paragachay deposits (Table 1; Fig. 5c), although the quality and accuracy of $\mathrm{Au}$ data must be treated with caution. For instance at Kadjaran, depending on the source of data (Table 1), the reported Au contents vary from $0.65 \mathrm{~g} / \mathrm{t}$ (Singer et al, 2002) to $0.02 \mathrm{~g} / \mathrm{t}$ (data communicated by the mine staff). In addition, further studies are required to understand if the reported $\mathrm{Au}$ grades are intimately associated with the porphyry event or result from a younger epithermal overprint, as recognized for instance at the Kadjaran deposit (e.g. Hovakimyan et al., 2015). In brief, although the highest Au grades are associated with Oligocene deposits, the data are too scarce and too unreliable to confidently conclude that collision to post-collision porphyry deposits associated with shoshonitic to adakitic magmatism in the Zangezur-Ordubad region are truly Au-enriched with respect to the subduction-related Eocene deposits. Based on the $\mathrm{Mo}$ and $\mathrm{Cu}$ grades, all deposits essentially qualify as porphyry $\mathrm{Cu}-\mathrm{Mo}$ deposits, regardless of their age (Fig. $5 \mathrm{c}$ ), and none can be coined as a typical porphyry $\mathrm{Cu}-\mathrm{Au}$ deposit based on the Au grades.

The essentially $\mathrm{Cu}-\mathrm{Mo}$-enriched signature of the porphyry deposits related to collision to post-collision tectonics and alkaline magmatism in the Zangezur-Ordubad region, involving a metasomatised lithospheric mantle source, is not unique. For instance, porphyry Cu-Mo deposits are also reported during the collision-related metallogenic evolution of the Tibetan orogenic belt, which is characterized by alkaline magmatism (Hou et al., 2011, 2015). Some of the Tibetan porphyry deposits are associated with large-scale, regional strike-slip faults (Hou et al., 2003), which is analogous to the fault-controlled metallogenic setting of the Zangezur-Ordubad region (e.g. Fig. 3b). The reported high-grade Au zones in the Tibetan deposits postdate and are unrelated to porphyry $\mathrm{Cu}$-Mo emplacement, and are attributed to overprinting high-sulphidation $\mathrm{Cu}-\mathrm{Au}$ mineralization (Hou et al., 2011). In a review on the metallogenic evolution of the Tethyan orogeny, Richards (2015) also includes porphyry $\mathrm{Cu} \pm \mathrm{Mo} \pm \mathrm{Au}$ in post-collisional settings (see Fig. 4D in Richards, 2015). This review points out that in fact the nature of porphyry deposits does not change significantly with different tectonic settings, i.e. Miocene post-collision Tibetan porphyry $\mathrm{Cu}-\mathrm{Mo}$ deposits are similar to Mesozoic subduction-related ones from the same region and from the Balkans and Chile. 
As discussed by Audétat (2010) in the case of the porphyry Mo deposit at Cave Peaks, Texas, U.S.A., the origin of Mo-enrichment in porphyry deposits is still a matter of debate. It is attributed either to assimilation of Mo-enriched crustal, basement rocks during magmatic evolution or, alternatively, to Mo-enrichment during progressive fractional crystallisation of mafic magmas. In the Zangezur-Ordubad region under study, the extensive range from mafic (gabbroic compositions) to felsic (granitic compositions) end-member rock types during the successive magmatic events is permissive with Audétat's model (2010), favouring Moenrichment in both Eocene and Oligocene porphyry deposits due to increasing degrees of magma fractionation. In addition, our radiogenic isotope data document that there is negligeable or no involvement of crustal, basement sources during Cenozoic magma evolution in the Zangezur-Ordubad region (Fig. 14). In another study, Pettke et al. (2010) concluded that the elevated Mo-endowment of porphyry deposits with alkaline magmatic affinities generated during post-subduction, late Eocene extension in the western U.S.A., including the Bingham Canyon deposit, was related to magmas originating from ancient, Moenriched lithospheric mantle metasomatised during a Proterozoic subduction event. In the light of the previous examples and our study in the Zangezur-Ordubad region, we conclude that porphyry $\mathrm{Cu}-\mathrm{Mo}$ deposits can also be generated in alkaline magmatic and collision to post-collision settings. In brief, the general inference that porphyry $\mathrm{Cu}-\mathrm{Au}$ deposits, rather than porphyry $\mathrm{Cu}-\mathrm{Mo}$ deposits, are associated with collision to post-collision settings and alkaline magmatism should be applied with caution, and requires further studies.

\subsection{Regional magmatic, geodynamic and metallogenic comparison of the southernmost Lesser Caucasus with the Cenozoic Alborz and Urumieh-Dokhtar belts of Iran}

Primitive-normalized spider diagrams with negative $\mathrm{Nb}$, $\mathrm{Ta}$ and $\mathrm{Ti}$ anomalies (Fig. 22) indicate a subduction-like magmatic source in the Lesser Caucasus, and the Iranian Alborz and northern Urumieh-Dokhtar belts throughout the Cenozoic. It is consistent with Eocene subduction-related magmatism along the Lesser Caucasus and Iran, and subsequent magma generation from a subduction-modified and subduction-inherited mantle wedge, following late Eocene-Oligocene Arabia-Eurasia/Iran collision, with collision progressively younging southwards along Iran (Agard et al., 2011). Verdel et al. (2011) document oceanic island arclike compositions during Oligo-Miocene magmatism in the Alborz segment north of Teheran (see area IV in Fig. 1). This suggests tapping of different proportions of subduction-modified mantle and unmodified asthenopsheric mantle reservoirs during Neogene magmatism along the Alborz.

By contrast, trace element diagrams reveal distinct differences of the Urumieh-Dokhtar belt with respect to the Alborz and the Zangezur-Ordubad region under study (Fig. 23). Magmatic 
rocks from the Urumieh-Dokhtar belt have an essentially normal arc, calk-alkaline composition, and are dominated by fluid-mobile components with only moderate slab-derived and mantle melt-derived components throughout the entire Cenozoic (Figs 23d, d, f, h). The exception are a few Miocene and Pliocene adakitic magmatic rocks, with a distinct slabenriched geochemistry, and characteristics of high-pressure magmatic evolution, attributed to slab melting and slab break-off following plate collision (Omrani et al., 2008; Yeganefahr et al., 2013).

The Alborz range and the Zangezur-Ordubad region have broadly similar magmatic evolutions during the Cenozoic. In both tectonic zones, Eocene magmatic rocks have a normal arc composition, dominated by fluid-mobile components and magmatic evolution in a lowpressure environment (Figs 23a, c, e, g). Akin to the Zangezur-Ordubad region, the Oligocene and Miocene magmatic rocks from the Alborz evolved towards adakitic compositions dominated by mantle melt-related enrichments and magmatic evolution in a higher-pressure environment (Figs 23a, c, e, g). According to Castro et al. (2013), adakitic magmatism started during early Oligocene in the Alborz. Oligocene shoshonitic magmatism is also documented by Aghazadeh et al. (2011) and Castro et al. (2013) in the western Alborz along the Caspian sea (see area III in Fig. 1). In contrast to the Zangezur-Ordubad region, melt-enrichment is more pronounced (Fig. 23c, high $\mathrm{Nb} / \mathrm{Y}$ ratios), and magmas evolved in a deeper storage environment (Fig. 23e, elevated $\mathrm{Sm} / \mathrm{Yb}$ ratios) during the Oligocene in the Alborz. The later may reflect a thicker crustal environment along the Alborz. This is supported by crustal thickness estimates of $\sim 42-44 \mathrm{~km}$ in the southernmost Lesser Caucasus by Gök et al. (2011), compared to slightly thicker estimates of $\sim 50-55 \mathrm{~km}$ in Central Iran, and the UrumiehDokhtar and Alborz belts by Mohammadi et al. (2013) and Motaghi et al. (2015).

The $\mathrm{Nd}$ and $\mathrm{Sr}$ isotope data reveal that the Meghri-Ordubad and Bargushat plutons, in particular the Neogene rock samples, have a more primitive, mantle-dominated composition in comparison to the majority of the Cenozoic magmatic rocks from the Urumieh-Dokhtar and Alborz belts, with generally lower ${ }^{143} \mathrm{Nd} /{ }^{144} \mathrm{Nd}$ and higher ${ }^{87} \mathrm{Sr} /{ }^{86} \mathrm{Sr}$ ratios reflecting more important crustal inputs in the Iranian belts (Fig. 14). Likewise, in the ${ }^{207} \mathrm{~Pb} /{ }^{204} \mathrm{~Pb}$ vs ${ }^{206} \mathrm{~Pb} /{ }^{204} \mathrm{~Pb}$ plot (Fig. 16a), Iranian magmatic rocks have an upper crust-dominated signature, falling predominantly above the orogenic $\mathrm{Pb}$ isotope evolutionary curve, whereas samples from the Meghri-Ordubad and Bargushat plutons plot below it, towards a more mantledominated reservoir. In the ${ }^{208} \mathrm{~Pb} /{ }^{204} \mathrm{~Pb}$ vs ${ }^{206} \mathrm{~Pb} /{ }^{204} \mathrm{~Pb}$ plot (Fig. 16b), the Iranian magmatic rocks plot well above the orogenic $\mathrm{Pb}$ isotope evolutionary curve towards the lower crust $\mathrm{Pb}$ isotope evolutionary curve, and have a distinct thorogenic signature when compared to samples from the Meghri-Ordubad and Bargushat plutons. In brief, the more radiogenic and thorogenic composition of Iranian Cenozoic magmatic rocks reflects more extensive 
assimilation of crustal rocks and/or the presence of older lower crustal basement in comparison to the magmatic rocks from the southernmost Lesser Caucasus.

Neogene shoshonitic and adakitic magmatism of the Alborz range, immediately to the south of our study area in the Zangezur-Ordubad region (area III in Fig. 1), is attributed to decompression melting of metasomatised lithospheric mantle during extension and thinning of the crust, and the adakitic composition is interpreted in terms of mantle metasomatism by slab-derived adakitic melts (Aghazadeh et al., 2011; Castro et al., 2013). This geodynamic evolution is comparable with the extensional flare-up evolution and asthenospheric upwelling scenario proposed by Verdel et al. (2011) for the late Eocene to Miocene evolution of northern and central Iran. However, the Oligo-Miocene extensional geodynamic evolution suggested for the Alborz region contrasts with the dominantly compressional tectonic environment, including crustal thickening, transpression, and translithospheric strike-slip faulting proposed in this study for the Zangezur-Ordubad region (Figs 21b-c). Although, as we stated above, $\mathrm{Sr} / \mathrm{Y}$ ratio and $\mathrm{Y}$ content patterns during early Oligocene shoshonitic magmatism at about 31.8-33.5 Ma (Figs 19c-d), may reflect a transient state of crustal thinning/extension in the Zangezur-Ordubad region. The reasons for the contrasting geodynamic evolutions of the two neighbouring tectonic zones are still unclear. The Zangezur-Ordubad region and the Alborz range are separated by the regional, orogentransverse Araks fault (Fig. 1), the geodynamic significance and the age of which remain uncertain (Sosson et al., 2010). Unlike the orogen-parallel Khustup-Giratakh and OrdubadSalvard dextral strike-slip faults (Figs $3 \mathrm{~b}$ and 21), the Araks fault appears to have had little to no control on the Cenozoic magmatic and metallogenic evolution. However, the Araks fault constitutes the oriental border of the South Armenian and the Kapan blocks, i.e. the southernmost Lesser Caucasus (Figs 1 and 3), where the Eastern Anatolian platform has indented the Eurasian margin (Fig. 2). This strong indentation tectonics, which is confined to the Lesser Caucasus, i.e. the Zangezur-Ordubad region, and its weaker impact along the Alborz (Fig. 2) may partly explain the, respectively, contrasting transpressive vs. extensional geodynamic evolutions.

Iranian porphyry deposits were emplaced during the Oligocene and Miocene along the Alborz/Arasbaran and Urumieh-Dokhtar belts, and the earliest reported porphyry deposits are 27-28 Ma old (Fig. 15 in Aghazadeh et al., 2015; see also Simmonds and Moazzen, 2015), which is comparable in age to the Oligocene Paragachay and Kadjaran deposits of the Zangezur-Ordubad region (Figs $3 \mathrm{~b}$ and 4 ). The Iranian porphyry deposits are also interpreted as post-collisional (e.g. Shafiei et al., 2009; Aghazadeh et al., 2015; Simmonds and Moazzen, 2015), and are related to post-collisional extension and lithospheric mantle delamination (see Fig. 16b in Aghazadeh et al., 2015). Like the divergent geodynamic evolutions discussed above, the extensional Iranian metallogenic setting constrasts with the transpressional setting 
proposed in our study for the Neogene porphyry deposits in the Zangezur-Ordubad region (Figs 20b-c). Another difference with respect to the metallogenic evolution of the Lesser Caucasus is the apparent absence of subduction-related Eocene porphyry deposits in the Iranian Alborz/Arasbaran and Urumieh-Dokhtar belts. Thus, we conclude that in contrast to the southernmost Lesser Caucasus, Eocene subduction tectonics and magmatism were not favourable for the generation of porphyry deposits along the Iranian Alborz/Arasbaran and Urumieh-Dokhtar belts.

\section{Conclusions}

This study have allowed us to clarify the magmatic, geodynamic and metallogenic evolution of the Zangezur-Ordubad region of the southernmost Lesser Caucasus, which links the Western and Central segments of the Tethyan orogenic and metallogenic belt with its Iranian extensions. Lithogeochemical and radiogenic isotope rock data together with $\mathrm{U}-\mathrm{Pb}$ zircon TIMS dating, and published Re-Os molybdenite ages allow us to subdivide the magmatic and metallogenic evolution of the Zangezur-Ordubad region in two broad stages. Eocene normal arc, calc-alkaline to high-K calc-alkaline magmatism was dominated by fluid-mobile components, and was coeval with Neotethys subduction and extensive Eocene magmatism in Iran. Small tonnage porphyry Cu-Mo deposits were emplaced during Eocene subduction.

Subsequent Oligocene and Mio-Pliocene magmatism coincided with Arabia-Eurasia collision to post-collision tectonics. Neogene magmatism was dominated by a depleted mantle component, compositionally modified by subducted sediments, added to the lithospheric mantle during the previous Eocene subduction event. Neogeone collision to post-collision magmatism was linked to asthenospheric upwelling along translithospheric, transpressional regional and orogen-parallel faults, located between the Gondwana-derived South Armenian and the Eurasian Kapan blocks. Decompression melting of metasomatised lithospheric mantle, and possibly juvenile lower crust, resulted in high-K calc-alkaline and shoshonitic to adakitic magmas, the ascent of which was favoured by the presence of long-lived translithospheric faults. Oligocene porphyry $\mathrm{Cu}-\mathrm{Mo}$ ore deposit formation, including the major Kadjaran and the Paragachay deposits at 26-27 Ma, took place during the collision to post-collision tectonic evolution of the Zangezur-Ordubad region. Further studies are required to clarify the exact temporal relationship of the Oligocene porphyry $\mathrm{Cu}-\mathrm{Mo}$ event with the early Oligocene shoshonitic and/or the late Oligocene to Mio-Pliocene adakitic magmatism.

The evolution and setting of the Zangezur-Ordubad region is comparable to the Tibetan geodynamic environment along the Asian segment of the Tethyan belt, where protracted Mesozoic to Cenozoic magmatism also resulted in the emplacement of successive generations of porphyry $\mathrm{Cu}-\mathrm{Mo}$ deposits. In parallel to the Tibetan case, our study in the Zangezur- 
Ordubad region demonstrates that porphyry $\mathrm{Cu}-\mathrm{Mo}$ deposits can also be generated by alkaline magmatism in collision to post-collision settings.

The southernmost Lesser Caucasus represents a unique and particularly fertile, long-lived geological environment along the Central Tethys orogenic and metallogenic belt, where longlived Cenozoic magmatism, and repeated Eocene and Oligocene porphyry-emplacement took place in successive subduction-related and collision to post-collision settings. This contrasts with the Iranian Alborz and Urumieh-Dokhtar Cenozoic magmatic and metallogenic belts, where only post-collisional Neogene porphyry $\mathrm{Cu}-\mathrm{Mo}$ deposits are reported.

\section{Acknowledgements}

The research was supported by the Swiss National Science Foundation through the research grants 200020-121510, 200020-138130 and 200020-155928 and the SCOPES Joint Research Projects IB7620-118901 and IZ73Z0-128324. Field work of H. Rezeau was supported by the Augustin Lombard Foundation of the Geneva SPHN Society and a Society of Economic Geology student research grant from the H.E. McKinstry Fund. S. Hovakimyan was supported by a post-doctoral Swiss Government Excellence Scholarship during 2014-2015. The authors would like to thank the staff of the Zangezur Copper-Molybdenum Combine and the Agarak Copper-Molybdenum Combine - GeoProMining for access to their mines, and the Azerbaijan International Mining Company for logistical support, property access and sample handling. We are grateful to the expert technical help provided by J.-M. Boccard and F. Capponi, University of Geneva, during thin section and sample preparation, and XRF analyses. This paper is dedicated to the memory of Vagif Ramazanov, our colleague from Baku, we will miss him; he was a great mentor to many students from the Lesser Caucasus. The authors would like to thank two anonymous reviewers for their excellent comments, and R. Goldfarb for editorial improvements. 


\section{References}

Achikgiozyan, S.O., Zohrabyan, S.A., Karapetyan, A.I., Mirzoyan, H.G., Sargisyan, R.A., Zaryan, R.N., 1987. The Kapan Mining District. Publishing House of the Academy of Sciences of the Armenian SSR, 198 p. (in Russian).

Adamia, Sh, A., Chkoutua, T., Kekelia, M., Lordkipanidze, M., Shavishvili, I., Zakariadze, G., 1981. Tectonics of the Caucasus and adjoining regions: implications for the evolution of the Tethys ocean. Journal of Structural Geology 3, 437-447.

Adamia, Sh., Alania, V., Chabukiani, A., Chichua, G., Enukidze, O., Sadradze, N., 2010. Evolution of the Late Cenozoic basins of Georgia (SW Caucasus): a review: In: Sosson, M., Kaymakci, N., Stephenson, R.A., Bergerat, F., \& Starostenko, V. (eds) Sedimentary basin tectonics from the Black Sea and Caucasus to the Arabian platform. Geological Society London, Spec. Publication 340, 239-259.

Adamia Sh., Zakariadze G., Chkhotua T., Sadradze N., Tsereteli N., Chabukiani A., Gventsdze A., 2011. Geology of the Caucasus: A Review. Turkish Journal of Earth Sciences 20, 489-544.

Agard, P., Omrani, J., Jolivet, L., Whitechurch, H., Vrielynck, B., Spakman, W., Monié, P., Meyer, B., Wortel, R., 2011. Zagros orogeny: a subduction-dominated process. Geological Magazine 148, 692-725.

Aghazadeh, M., Castro, A., Omran, N.R., Emami, M.H. Moinvaziri, H., Badrzadeh, Z., 2010. The gabbro (shoshonitic)-monzonite-granodiorite association of Khankandi pluton, Alborz Mountains, NW Iran. Journal of Asian Earth Sciences 38, 199-219.

Aghazadeh, M., Castro, A., Badrzadeh, Z., Vogt, K., 2011. Post-collisional polycyclic plutonism from the Zagros hinterland: the Shaivar Dagh plutonic complex, Alborz belt, Iran. Geological Magazine 148, 980-1008.

Aghazadeh ; M., Hou, Z., Badrzadeh, Z., Zhou, L. 2015. Temporal-spatial distribution and tectonic setting of porphyry copper deposits in Iran: Constraints from zircon $\mathrm{U}-\mathrm{Pb}$ and molybdenite $\mathrm{Re}-$ Os geochronology. Ore Geology Reviews 70, 385-406.

Ahmadian, J., Haschke, M., McDonald, I., Regelous, M., Reza Ghorbani, M., Emami, M.H., Murata, M., 2009. High magmatic flux during Alpine-Himalayan collision: constraints from the Kal-eKafi complex, central Iran. Geological Society of America Bulletin 121, 857-868.

Alavi, M., 2007. Structures of the Zagros fold-thrust belt in Iran. American Journal of Sciences 307, 1064-1095.

Allen, M.B., Armstrong, H.A., 2008. Arabia-Eurasia collision and the forcing of mid-Cenozoic global cooling. Palaeogeography, Palaeoclimatology, Palaeoecology 265, 52-58.

Alonso-Perez, R., Müntener, O., Ulmer, P., 2009. Igneous garnet and amphibole fractionation in the roots of island arcs: Experimental constraints on andesitic liquids: Contributions to Mineralogy and Petrology 157, 541-558.

Amiryan, Sh.H., 1984. Gold ore formation of Armenian SSR. Yerevan. Publishing House of the Academy of Sciences of the Armenian SSR, 304 p. (in Russian).

Amiryan, Sh. O., Karapetyan, A.I., 1964. Mineralogical-geochemical characteristics of the ores of the Mehgradzor gold deposit. Izvestia Academy of Sciences Armenian SSR, Nauki o Zemle, 2, 37 48 (in Russian).

Amiryan, S. H., Pidjyan G.H., Faramazyan A.S., 1987. Mineralization stages and ore minerals of the Teghout ore deposit. Izvestia Academy of Sciences Armenian SSR, Nauki o Zemle, 4, 31-44 (in Russian with English abstract).

Asiabanha, A., Foden, J., 2012. Post-collisional transition from an extensional volcano- sedimentary basin to a continental arc in the Alborz Ranges, N-Iran. Lithos 148, 98-111.

Aslanyan, A.T., 1958, Regional geology of Armenia. Haypetrat Edition, Yerevan, Armenia 430 p. (in Russian).

Audétat, A. 2010. Source and evolution of molybdenum in the porphyry Mo(-Nb) deposit at Cave Peak,Texas. Journal of Petrology 51, 1739-1760.

Avagyan, A., Sosson, M., Philip, M.H., Karakhanian, A., Rolland, Y., Melkonyan, R., Rebai, S., Davtyan, V., 2005. Neogene to Quaternary stress field evolution in Lesser Caucasus and adjacent regions using fault kinematics analysis and volcanic cluster data. Geodinamica Acta 18, $401-416$. 
Azizi, H., Jahangiri, A., 2008. Cretaceous subduction-related volcanism in the northern SanandajSirjan Zone, Iran. Journal of Geodynamics 45, 178-190.

Azizi, H., Moinevaziri, H., 2009. Review of the tectonic setting of Cretaceous to Quaternary volcanism in northwestern Iran. Journal of Geodynamics 47, 167-179.

Azizi, H., Asahara, Y., Tsuboi, M., Takemura, K., Razyani, S., 2014. The role of heterogenetic mantle in the genesis of adakites northeast of Sanandaj, northwestern Iran. Chemie der Erde 74, 87-97.

Babazadeh, V.M., Makhmudov, A.I., Ramazanov, V.G., 1990. Porphyry-copper and molybdenum deposits. Azerbaijan Publication, Baku, 377 p. (In Russian with German and English abstracts).

Bachmann, O., Dungan, M.A., Bussy, F., 2005. Insights into shallow magmatic processes in large silicic magma bodies: The trace element record in the Fish Canyon magma body, Colorado. Contributions to Mineralogy and Petrology 149, 338-349.

Bagdasaryan, G.P., Gukasyan, R.Kh., Karamyan, K.A., 1969. Absolute dating of Armenian ore formations. International Geology Review 11, 1166-1172.

Bagdasaryan, G.P., Ghoukassyan, R.K., Kazaryan, K.B., 1978. Comparative study of the age of old metamorphic schists in the Hakhoum River Basin (Armenian SSR) by means of $\mathrm{K}-\mathrm{Ar}$ and $\mathrm{Rb}-$ Sr techniques. Geochronology of the Eastern-European Platform and Junction of the CaucasianCarpathian System. Nauka, 47-58 (in Russian).

Ballato, P., Uba, C.E., Landgraf, A., Strecker, M.R., Sudo, M., Stockli, D.F., Friedrich, A., Tabatabaei, S.H., 2011. Arabia-Eurasia continental collision: Insights from late Tertiary foreland-basin evolution in the Alborz Mountains, northern Iran. Geological Society of America Bulletin 123, 106-131.

Barboni, M., Schoene, B., Ovtcharova, M., Bussy, F., Schaltegger, U., Gerdes, A., 2013. Timing of incremental pluton construction and magmatic activity in a back-arc setting revealed by IDTIMS U/Pb and Hf isotopes on complex zircon grains. Chemical Geology 342, 76-93.

Barrier, E., Vrielynck, B. (Eds.), 2008. Palaeotectonic Maps of the Middle East. CGMW.

Bazhenov, M.L., Burtman, V.S., Levashova, N.L., 1996. Lower and Middle Jurassic paleomagnetic results from the south Lesser Caucasus and the evolution of the Mesozoic Tethys ocean. Earth and Planetary Science Letters 141, 79-89.

Behn, M.D., Kelemen, P.B., Hirth, G., Hacker, B.R., Massonne, H.-J., 2011. Diapirs as the source of the sediment signature in arc lavas. Nature Geoscience 4, 641-646.

Belov, A.A., 1968. On the history of tectonic development of the northern margin of the Iranian Elibaykal subplatform on Lesser Caucasus. Izvestia of the Academy of Sciences of SSSR, volume geology 10, 121-129 (in Russian).

Belov, A.A., 1969. Stratigraphy and structure of metamorphic volcanogenic and sedimentary stages of the Hanqavan-Zangezur fault in south-east Armenia. Bulletin MOIP, section geology, X IV, 6577 (in Russian).

Bindeman, I.N., Eiler, J.M., Yogodzinski, G.M., Tatsumi, Y., Sterne, C.R., Grove, T.L., Portnyagin, M., Hoernle, K., Danyushevsky, L.V., 2005. Oxygen isotope evidence for slab melting in modern and ancient subduction zones. Earth and Planetary Science Letters 235, 480- 496.

Bird, P., 1979. Continental delamination and the Colorado Plateau. Journal of Geophysical Research 84, 7561-7571.

Black, L. P., Kamo, S. L., Allen, C. M., Davis, D. W., Aleinikoff, J. N., Valley, J. W., et al. 2004. Improved ${ }^{206} \mathrm{~Pb} /{ }^{238} \mathrm{U}$ microprobe geochronology by the monitoring of a trace element-related matrix effect; SHRIMP, ID-TIMS, ELA-ICP-MS and oxygen isotope documentation for a series of zircon standards. Chemical Geology 205, 115-140.

Bowring, J. F., Mclean, N. M., Bowring, S. A., 2011. Engineering cyber infrastructure for U-Pb geochronology: Tripoli and U-Pb_Redux. Geochemistry Geophysics Geosystems 12, Q0AA19.

Brunet, M.-F., Korotaev, M.V., Ershov, A.V., Nikishin, A.M., 2003. The South Caspian Basin: a review of its evolution from subsidence modelling. Sedimentary Geology 156, 119-148

Burtman, V.S., 1994. Meso-Tethyan oceanic sutures and their deformation. Tectonophysics 234, 305327.

Castro, A., Aghazadeh, M., Badrzadeh, Z., Chichorro, M, 2013. Late Eocene-Oligocene postcollisional monzonitic intrusions from the Alborz magmatic belt, NW Iran. An example of monzonite magma generation from a metasomatized mantle source. Lithos 180-181, 109-127. 
Chiaradia, M., 2009. Adakite-like magmas from fractional crystallization and melting assimilation of mafic lower crust (Eocene Macuchi arc, Western Cordillera, Ecuador). Chemical Geology 265, 468-487.

Chiaradia, M., Müntener, O., Beate, B., 2011. Enriched basaltic andesites from mid-crustal fractional crystallization, recharge, and assimilation (Pilavo Volcano, Western Cordillera of Ecuador). Journal of Petrology 52, 1107-1141.

Chiu, H.-Y., Chung, S.-L., Zarrinkoub, M.H., Mohammadi, S.S., Khatib, M.M., Iizuka, Y., 2013. Zircon $\mathrm{U}-\mathrm{Pb}$ age constraints from Iran on the magmatic evolution related to Neotethyan subduction and Zagros orogeny. Lithos 162-163, 70-87.

Conceição, R.V., Green, D.H., 2004. Derivation of potassic (shoshonitic) magmas by decompression melting of phlogopite + pargasite lherzolite. Lithos 72, 209-229.

Condon, D., Mclean, N., Schoene, B., Bowring, S., Parrish, R., Noble, S., 2008. Synthetic U-Pb 'standard' solutions for ID-TIMS geochronology. Geochimica et Cosmochimica Acta 72 (12S), A175.

Coplen, T.B., Kendall, C., Hopple, J., 1983. Comparison of stable isotope reference samples. Nature 302, 236-238.

Crowley, J., Schoene, B., Bowring, S., 2007. U-Pb dating of zircon in the Bishop Tuff at the millennial scale. Geology 35, 1123-1126.

Davidson, J., Turner, S., Handley, H., Macpherson, C., and Dosseto, A., 2007. Amphibole "sponge" in arc crust? Geology 35, 787-790.

Delibas, O., Moritz, R., Ulianov, A., Chiaradia, M., Saraç, C., Revan, K., Göç, D., in press. Cretaceous subduction-related magmatism and associated porphyry-type $\mathrm{Cu}-\mathrm{Mo}$ mineralizations in the Eastern Pontides, Turkey: New constraints from geochronology and geochemistry. Lithos.

DePaolo, D.J., 1988. Neodymium Isotope Geochemistry: An Introduction. Springer, Heidelberg, 187 p.

Dilek, Y., Imamverdiyev, N., Altunkaynak, S., 2009. Geochemistry and tectonics of Cenozoic volcanism in the Lesser Caucasus (Azerbaijan) and the peri-Arabian region: Collision-induced mantle dynamics and its magmatic fingerprint. International Geology Review 52, 536-578.

Djrbashyan R.T., Guyumdjyan H.P., Tayan R.N., 1976. Some features of the structure and formation of the Tertiary volcanic and sedimentary sequences of Zangezur (south-eastern part of Armenian SSR). In: "Volcanism and metallogeny of Armenian SSR". Publishing House of the Academy of Sciences of the Armemian SSR, Yerevan 8, 60-77.

Eiler, M., 1991. Oxygen isotope variations of basaltic lavas and upper mantle rocks. In: J.W. Valley, andD.R. Cole (Eds.), Stable Isotope Geochemistry, Reviews in Mineralogy and Geochemistry 43, 319- 364 .

Eppelbaum, L.V., Khesin, B.E. 2012. Geophysical studies in the Caucasus. Lecture Notes in Earth System Sciences, Springer Berlin Heidelberg, 393 p.

Feldstein, S.N., Lange, R.A., 1999. Pliocene potassic magmas from the Kings River region, Sierra Nevada, California: evidences for melting of a subduction-modified mantle. Journal of Petrology 40, 1301-1320.

Frey, F.A., Chappell, B.W., Roy, S.D., 1978. Fractionation of rare-earth elements in the Tuolumne Intrusive Series, Sierra Nevada batholith, California. Geology 6, 239-242.

Gabrielyan, A.A., Nazaretyan, S.N., Ohannisyan, Sh.S., 1989. Deep faults of the territory of Armenia. In : Nauka M (ed) Geodynamics of Caucasus, 36-45 (in Russian).

Galoyan, G., Rolland, Y., Sosson, M., Corsini, M., Melkonyan, R., 2007. Evidence for superposed MORB, oceanic plateau and volcanic arc series in the Lesser Caucasus (Stepanavan, Armenia). Comptes Rendus Geosciences 339, 482-492.

Galoyan, G., Rolland, Y., Sosson, M., Corsini, M., Billo, S., Verati, C., Melkonyan, R., 2009. Geology, geochemistry and ${ }^{40} \mathrm{Ar} /{ }^{39} \mathrm{Ar}$ dating of Sevan ophiolites (Lesser Caucasus, Armenia): Evidence for Jurassic back-arc opening and hot spot event between the South Armenian Block and Eurasia. Journal of Asian Earth Sciences 34, 135-153.

Gamkrelidze, I.P., 1986. Terranes of the Caucasus and adjacent areas. Tectonophysics 127, 261-277.

Gamkrelidze, I.P., 1997. Geodynamic evolution of the Caucasus and adjacent areas in Alpine time. Bulletin of the Georgian National Academy of Sciences 155, 391-394. 
Gamkrelidze, I.P., Shengelia, D.M., 2007. Pre-Alpine geodynamics of the Caucasus, suprasubduction regional metamorphism and granitoid magmatism. Bulletin of the Georgian National Academy of Sciences 175, 57-65.

Gevorkyan, R., Aslanyan, A., 1997. Armenia. In: Moores, E.M., Fairbridge, R.W. (Eds.), Encyclopedia of European and Asian Regional Geology. Chapman and Hall, London, 26-34.

Ghazi, A.M., Pessagno, E.A., Hassanipak, A.A., Kariminia, S.M., Duncan, R.A., Babaie, H.A., 2003. Biostratigraphic zonation and ${ }^{40} \mathrm{Ar} /{ }^{39} \mathrm{Ar}$ ages for the Neotethyan Khoy ophiolite of NW Iran. Palaeogeography, Palaeoclimatology, Palaeoecology 193, 311-323.

Ghukasyan R.Kh., 1966. The ages division of the intrusions Meghri pluton according argon method. In: Absolute dating of tectonic-magmatic cycles and stages of mineralization, on data 1964. Publishing House of the Academy of Sciences SSSR, Moskau, 41-50.

Ghukasyan, R.Kh., Tayan, R.N., Haruntunyan, M.A., 2006. Rb-Sr investigations of magmatic rocks of Kadjaran ore field (Republic of Armenia). In: Isotope dating of processes of ore mineralization, magmatism, sedimentation and metamorphism. Materials of III Russian conference on isotope geochronology I, 213-216.

Gök, R., Mellors, R. J., Sandvol, E., Pasyanos, M., Hauk, T., Takedatsu, R., Yetirmishli, G., Teoman, U., Turkelli, N., Godoladze, T., Javakishvirli, Z., 2011. Lithospheric velocity structure of the Anatolian plateau - Caucasus - Caspian region. Journal of Geophysical Research 116, B05303.

Golonka, J., 2004. Plate tectonic evolution of the southern margin of Eurasia in the Mesozoic and Cenozoic. Tectonophysics 381, 235-273.

Green, T.H., Pearson, N.J., 1985. Experimental determination of REE partition coefficients between amphibole and basaltic to andesitic liquids at high pressure. Geochimica et Cosmochimica Acta 49, 1465-1468.

Guest, B., Stockli, D.F., Grove, M., Axen, G.J., Lam, P.S., Hassanzadeh, J., 2006. Thermal histories from the central Alborz Mountains, northern Iran: implications for the spatial and temporal distribution of deformation in northern Iran. Geological Society of America Bulletin 118, 15071521.

Gugushvili, V., 2004. Two types of gold mineralization in the Bolnisi mining district related to Cretaceous volcanism. Proceedings Geological Institute of the Georgian Academy of Science, new series 119, 749-755.

Hanson, G.N., 1980. Rare earth elements in petrogenetic studies of igneous systems. Annual Review of Earth Planetary Sciences 8, 371-406.

Harutunyan, M.A., Tayan, R.N., Sarkisyan, S.P., 2002. Porphyry dikes of the Kadjaran ore field. Volume of the scientific session dedicated to the $90^{\text {th }}$ anniversary of S.A. Movsesyan, National Academy of Sciences of the Republic of Armenia, Yerevan, 45-52.

Haschke, M., Günther, A., Melnick, D., Echtler, H., Reutter, K.-J., Scheuber, E., Oncken, O., 2006. Central and Southern Andean tectonic evolution inferred from arc magmatism. In: Oncken, O., Chong, G., Franz, G., Giese, P., Götze, H.-J., Ramos, V.A., Strecker, M.R., and Wigger, P., Frontiers in Earth Sciences The Andes, Springer Berlin Heidelberg, 337-353.

Haschke, M., Ahmadian, J., Murata, M., McDonald, I., 2010. Copper mineralization prevented by arcroot delamination during Alpine-Himalayan collision in Central Iran. Economic Geology 105, $855-865$.

Hassanipak, A.A., Mohamad Ghazi, A., 2000. Petrology, geochemistry and tectonic setting of the Khoy ophiolite, northwest Iran: implications for Tethyan tectonics. Journal of Asian Earth Sciences 18, 109-121.

Hassanpour, S., Alirezaei, S., Selby, D., Sergeev, S., 2015. SHRIMP zircon U-Pb and biotite and hornblende $\mathrm{Ar}-\mathrm{Ar}$ geochronology of Sungun, Haftcheshmeh, Kighal, and Niaz porphyry $\mathrm{Cu}-$ Mo systems: evidence for an early Miocene porphyry-style mineralization in northwest Iran. International Journal of Earth Sciences 104, 45-59.

Hässig, M., Rolland, Y., Sosson, M., Galoyan, G., Müller, C., Avagyan, A., Sahakyan, L., 2013a. New structural and petrological data on the Amasia ophiolites (NW Sevan-Akera suture zone, Lesser Caucasus): Insights for a large-scale obduction in Armenia and NE Turkey. Tectonophysics 588, $135-153$ 
Hässig, M., Rolland, Y., Sosson, M., Galoyan, G., Sahakyan, L., Topuz, G., Celik O.F., Avagyan, A., Müller, C., 2013b. Linking the NE Anatolian and Lesser Caucasus ophiolites: evidence for large-scale obduction of oceanic crust and implications for the formation of the Lesser Caucasus-Pontides Arc. Geodinamica Acta 26, 311-330.

Hässig, M., Rolland, Y., Sahakyan, L., Sosson, M., Galoyan, G., Avagyan, A., Bosch, D., Müller, C. 2015. Multi-stage metamorphism in the South Armenian Block during the Late Jurassic to Early Cretaceous: Tectonics over south-dipping subduction of Northern branch of Neotethys. Journal of Asian Earth Sciences 102, 4-23.

Hemon, P., Moritz, R., Vagif, R., 2012. The Gedabek epithermal Cu-Au deposit, Lesser Caucasus, Western Azerbaijan: geology, alterations, petrography and evolution of the fluid sulfidation states. Abstract Volume, 10th Swiss Geoscience Meeting, November 2012, Bern, 120-121.

Hermann, J., Rubatto, D., 2009. Accessory phase control on the trace element signature of sediment melts in subduction zones. Chemical Geology 265, 512-526.

Hildreth, W., and Moorbath, S., 1988. Crustal contribution to arc magmatism in the Andes of central Chile. Contributions to Mineralogy and Petrology 98, 455-489.

Honarmand, M., Rashidnejad Omran, N., Neubauer, N., Emami, M.H., Nabatian, G., Liu, X., Donge, Y., von Quadt, A., Chen, B., 2014. Laser-ICP-MS U-Pb zircon ages and geochemical and Sr$\mathrm{Nd}-\mathrm{Pb}$ isotopic compositions of the Niyasar plutonic complex, Iran: constraints on petrogenesis and tectonic evolution. International Geology Review 56, 104-132.

Hou, Z.Q., Ma, H.W., Zaw, K., Zhang, Y.Q., Wang, M.J., Wang, Z., Pan, G.T., Tang, R.L., 2003. The Himalayan Yulong porphyry copper belt: product of large-scale strike-slip faulting in eastern Tibet. Economic Geology 98, 125-145.

Hou, Z., Zhang, H., Pan, X., Yang, Z., 2011. Porphyry $\mathrm{Cu}(-\mathrm{Mo}-\mathrm{Au})$ deposits related to melting of thickened mafic lower crust: Examples from the eastern Tethyan metallogenic domain. Ore Geology Reviews 39, 21-45.

Hou, Z., Yang, Z., Lu, Y., Kemp, A., Zheng, Y., Li, Q., Tang, J., Yang, Z., Duan, L., 2015. A genetic linkage between subduction- and collision-related porphyry $\mathrm{Cu}$ deposits in continental collision zones. Geology 43, 247-250.

Hovakimyan S.E., 2008. Geological and structural conditions of the formation of the Lichk coppermolybdenum deposit (Southern Armenia). Proceedings of the National Academy of Sciences of the Republic of Armenia, Earth Sciences, No.1, 21-24 (in Russian with English abstract).

Hovakimyan S.E., 2010. Geological and structural conditions of the formation of the Lichkvaz-Tey gold deposit (South Armenia). Proceedings of the National Academy of Sciences of the Republic of Armenia, Earth Sciences, №1, 22-29 (in Russian with English abstract).

Hovakimyan S.E., Tayan R.N., 2008. Fractures of the Lichk-Ayguedzor ore field and mineralization controls. Proceedings of the National Academy of Sciences of the Reublic of Armenia, Earth Sciences 61, 3-12, (in Russian with English abstract).

Hovakimyan S.E., Tayan R.N., Moritz R., Harutyunyan M.A., Hovhannisyan A.E., 2014a. Structural features of the Kajaran ore field and world-class Mo-Cu porphyry deposit, Southern Armenia, Lesser Caucasus. 12th Swiss Geoscience Meeting, 21 - 22 November 2014, Fribourg, abstract volume, 80.

Hovakimyan S.E., Tayan R.N., Moritz R., Melkonyan R.L., Harutyunyan M.A., Hovhannisyan A.E., 2014b. The structural control of the major Mo-Cu-porphyries and Au - polymetallic deposits of the Tertiary Meghri composite pluton, Tethys metallogenic belt, Lesser Caucasus, Southern Armenia. SEG 2014 Conference: Building Exploration Capability for the 21st Century, 27-30 September 2014, Keystone, CO, USA, electronic abstract volume.

Hovakimyan S., Moritz R., Tayan R., Harutyunyan M., Rezeau H., 2015. The world-class Kadjaran Mo-Cu-porphyry deposit, Southern Armenia, Lesser Caucasus: structural controls, mineral paragenesis and fluid evolution. In: André-Mayer, A.-S., Cathelineau, M., Muchez, P., Pirad, E., $\&$ Sindern S. (eds) Mineral resources in a sustainable world, 13th SGA Biennial Meeting, 24-27 August 2015, France, Nancy 1, p.295-298.

Ismail-Zade, A.D., Veliev, M.M., Mamedov, M.M., Bagirov, A.E., 1995. Tectonic position of the Talysh mafic- ultramafic complex. Geotectonics 29, 184-186. 
Ismet, A.R., Hassanov, R.K., Abdullaev, I.A., Bagirbekova, O.D., Jafarova, R.S., Jafarov, S.A., 2003. Radiochronological study of geological formations of Azerbaijan. Nafta-Press, Baku, Azerbaijan, $191 \mathrm{p}$.

Jackson, S.E., 2008. Lamtrace data reduction software for LA-ICP-MS. In: Sylvester, P. (Ed.), Laser Ablation ICP-MS in the Earth Sciences: Current Practices and Outstanding Issues. volume 40 of Short Course Series. Mineralogical Association of Canada, 305-307.

Jamali, H., Dilek, Y., Daliran, F., Yaghubpur, A., Mehrabi, B. 2010. Metallogeny and tectonic evolution of the Cenozoic Ahar-Arasbaran volcanic belt, northern Iran. International Geology Review 52, 608-630.

Jankovic, S. 1977. The copper deposits and geotectonic setting of the Tethyan Eurasian metallogenic belt. Mineralium Deposita 12, 37-47.

Jankovic, S. 1997. The Carpatho-Balkanides and adjacent area: a sector of the Tethyan Eurasian metallogenic belt. Mineralium Deposita 32, 426-433

Jourdan, A.-L., Vennemann, T.W., Mullis, J., Ramseyer, K., 2009. Oxygen isotope sector zoning in natural hydrothermal quartz. Mineralogical Magazine 73, 615-632.

Jureau, T., 2004. The ophiolites of Khoy (NW Iran): their significance in the Tethyan ophiolite belts of the Middle-East. Comptes Rendus Geoscience 336, 105-108.

Kamvong, T., Zaw, K., Meffre, S., Maas, R., Stein, H., Lai, C.-K., 2014. Adakites in the Truong Son and Loei fold belts, Thailand and Laos: Genesis and implications for geodynamics and metallogeny. Gondwana Research 26, 165-184.

Karamyan K.A. 1962. The structure and the conditions of formation of the Dastakert coppermolybdenum deposit. Yerevan: Publishing House of the Academy of Sciences of the Armenian SSR, 185 p. (in Russian).

Karamyan, K.A., 1978. Geology, structure and condition of formation copper-molybdenum deposits of Zangezour ore region. Yerevan; Publishing House of the Academy of Sciences Armenian SSR, 179 p. (in Russian).

Karamyan K.A., Tayan R.N., Guyumdjyan O.P. 1974. The main features of intrusion magmatism Zangezur region of the Armenian SSR. Izvestia of Academy of Sciences of Armenian SSR, Nauki o Zemle, No.1, p. 54-65.

Kay, S.M., Mpodozis, C., 2001. Central Andean ore deposits linked to evolving shallow subduction systems and thickening crust. GSA Today 11, 4-9.

Kazmin, V.G., Sbortshikov, I.M., Ricou, L.-E., Zonenshain, L.P., Boulin, J., Knipper, A.L., 1986. Volcanic belts as markers of the Mesozoic-Cenozoic active margin of Eurasia. Tectonophysics $123,123-152$.

Kekelia, S., Kekelia, M., Otkhmezuri, Z., Ozgür, N., Moon, C., 2004. Ore-forming systems in volcanogenic-sedimentary sequences by the example of base metal deposits of the Caucasus and East Pontic Metallotect. Bulletin of Mineral Research and Exploration 129, 1-16.

Kelemen, P.B., Yogodzinski, G.M., Scholl, D.W., Eiler, J.M., 2003. Along-strike variation in the Aleutian island arc: genesis of high $\mathrm{Mg} \#$ andesite and implications for continental crust. Geophysical Monograph 138, 223-276.

Kepezhinskas, P., McDermott, F., Defant, M.J., Hochstaedter, A., Drummond, M.S., Hawkesworth, C.J., Koloskov, A., Maury, R.C., Bellon, H., 1997. Trace element and $\mathrm{Sr}-\mathrm{Nd}-\mathrm{Pb}$ isotopic constraints on a three-component model of Kamchatka arc petrogenesis. Geochimica et Cosmochimica Acta 61, 577-600.

Khain, V.E., 1975. Structure and main stages in the tectono-magmatic development of the Caucasus: an attempt at geodynamic interpretation. American Journal of Science 275-A, 131-156.

Khalatbari-Jafari, M., Juteau, T., Cotten, J., 2006. Petrological and geochemical study of the Late Cretaceous ophiolite of Khoy (NW Iran), and related geological formations. Journal of Asian Earth Sciences 27, 465-502.

Knipper, A.L., Khain, E.V., 1980. Structural position of ophiolites of the Caucasus: Ofioliti 2, 297-314.

Kozerenko, S.V., 2004. Hydrothermal system of the Zod gold sulfide deposit, Armenia: Ore sources and formation conditions. Geochemistry International 42, 188-190.

Krogh, T. E., 1973. A low contamination method for the hydrothermal decomposition of zircon and extraction of $\mathrm{U}$ and $\mathrm{Pb}$ for isotopic age determinations. Geochimica et Cosmochimica Acta 37, 485-494. 
Le Maître, R.W. (ed.), 2002. Igneous rocks. A classification and glossary of terms. Recommendations of the International Union of Geological Sciences subcommission on the systematics of igneous rocks: Cambridge University Press, Cambridge, New York, Melbourne, 236 p.

Levitan, G., 2008. Gold deposits of the CIS. Xlibris corporation, Bloomington, Indiana, USA, 352 p.

Liu, S-A., Li, S., He, Y., Huang, F., 2010. Geochemical contrasts between early Cretaceous orebearing and ore-barren high-Mg adakites in central-eastern China: Implications for petrogenesis and $\mathrm{Cu}-\mathrm{Au}$ mineralization. Geochimica et Cosmochimica Acta 74, 7160-7178.

Lordkipanidze, M., Meliksetian, B., Djarbashian, R., 1989. Mesozoic-Cenozoic magmatic evolution of the Pontian Crimean-Caucasus region. Mémoire de la Société Géologique de France 154, 103 124.

Lu, Y.-J., Kerrich, R., Mccuaig, T.C., Li, Z.-X., Hart, C.J.R., Cawood, P.A., Hou, Z.-Q., Bagas, L., Cliff, J., Belousova, E.A., Tang, S.H., 2013. Geochemical, Sr-Nd-Pb, and Zircon Hf-O Isotopic Compositions of Eocene-Oligocene Shoshonitic and Potassic Adakite-like Felsic Intrusions in Western Yunnan, SW China: Petrogenesis and Tectonic Implications. Journal of Petrology 54, 1309-1348.

Ludwig, K.R., 2005. User's manual for ISOPLOT/Ex 3.22. A Geochronological Toolkit for Microsoft Excel. Berkeley Geochronology Center Special Publication. (71 pp. http://www.bgc.org/klprogrammenu.html).

Maksimov, A. P., 2009. The influence of water on the temperature of amphibole stability in melts. Journal of Volcanology and Seismology 3, 27-33.

Mamani, M., Wörner, G., Sempere, T., 2010, Geochemical variations in igneous rocks of the central Andean orocline $\left(13^{\circ} \mathrm{S}-18^{\circ} \mathrm{S}\right)$ : Tracing crustal thickening and magma generation through time and space. Geological Society of America Bulletin 122, 162-182.

Marchev, P., Kaiser-Rohrmeier, M., Heinrich, C., Ovtcharova, M., Von Quadt, A., Raicheva, R., 2005. Hydrothermal ore deposits related to post-orogenic extentional magmatism and core complex formation: The Rhodope Massif of Bulgaria and Greece. Ore Geology Reviews 27, 53-89.

Martin, H., Smithies, R.H., Rapp, R., Moyen, J.F., Champion, D., 2005. An overview of adakite, tonalite-trondhjemite-granodiorite (TTG), and sanukitoid: relationships and some implications for crustal evolution. Lithos 79, 1-24.

Mattey, D., Lowry, D., Macpherson, C., 1994. Oxygen isotope composition of mantle peridotite. Earth and Planetary Science Letters 128, 231-241.

Mattinson, J., 2005. Zircon U-Pb chemical abrasion ("CA-TIMS") method: combined annealing and multi-step partial dissolution analysis for improved precision and accuracy of zircon ages. Chemical Geology 220, 47-66.

Mayringer, F., Treloar, P.J., Gerdes, A., Finger, F., Shengelia, D., 2011. New age data from the Dzirula Massif, Georgia: Implications for the evolution of the Caucasian Variscides. American Journal of Science 311, 404-441.

McQuarrie, N., van Hinsbergen, D.J.J., 2013. Retrodeforming the Arabia-Eurasia collision zone: Age of collision versus magnitude of continental subduction. Geology 41, 315-318.

McQuarrie, N., Stock, J.M., Verdel, C., Wernicke, B.P., 2003. Cenozoic evolution of the Neotethys and implications for the causes of plate motions. Geophysical Research Letters 30, 1-6.

Mederer, J., Moritz, R., Ulianov, A., Chiaradia, M., 2013. Middle Jurassic to Cenozoic evolution of arc magmatism during Neotethys subduction and arc-continent collision in the Kapan Zone, southern Armenia. Lithos 177, 61-78.

Mederer, J., Moritz, R., Zohrabyan, S., Vardanyan, A., Melkonyan, R., Ulianov, A., 2014. Base and precious metal mineralization in Middle Jurassic rocks of the Lesser Caucasus - A review of geology and metallogeny and new data from the Kapan, Alaverdi and Drmbon districts. Ore Geology Reviews 58, 185-207.

Meissner, R., Mooney, W., 1998. Weakness of the lower continental crust: a condition for delamination, uplift, and escape. Tectonophysics 296, 47-60.

Melkonyan, R.L., Khorenian, R.A., Chiboukhchian, Z.H., 2000. On the issue of the Mesozoic magmatism in the Tsahkounk-Zanghezour zone of the Lesser Caucasus. Proceedings of the National Academy of Sciences of the Republic of Armenia, Earth Sciences 53, 17-29 (in Russian with English abstract). 
Melkonyan, R.L., Ghukasian, R.Kh., Tayan, R.N., Haruntunyan, M.A., 2008. Geochronometry of the Meghri pluton monzonites (Armenia) - results and consequences. Proceedings of the National Academy of Sciences of the Republic of Armenia 61, 3-9 (in Russian with English abstract).

Melkonyan, R.L., Ghukasian, R.Kh., Tayan, R.N., Khorenyan, R.A., Hovakimyan, S.E., 2010. The stages of copper-molybdenum ore formation in Southern Armenia (by the results of $\mathrm{Rb}-\mathrm{Sr}$ isotope age estimations). Proceedings of the National Academy of Sciences of the Republic of Armenia 63, 21-32 (in Russian with English abstract).

Middlemost, E.A.K., 1994. Naming materials in the magma/igneous rock system. Earth-Science Reviews 37, 215-224.

Migineishvili, R., 2005. Hybrid nature of the Madneuli $\mathrm{Cu}-\mathrm{Au}$ deposit, Georgia. Geochemistry, Mineralogy and Petrology (J. Bulg. Acad. Sci.), v. 43, p. 128-132.

Mkrtchyan S.S., Karamyan K.A., Arevshaytan T.A., 1969. The Kadjaran copper-molybdenum deposit. Publishing House of the Academy of Sciences Armenian SSR, Yerevan. 326 p. (in Russian).

Mohajjel M., Fergusson, C.L., 2000. Dextral transpression in Late Cretaceous continental collision, Sanandaj-Sirjan zone, western Iran. Journal of Structural Geology 22, 1125-1139.

Mohammadi, E., Sodoudi, F., Kind, R., Rezapour, M., 2013. Presence of a layered lithosphere beneath the Zagros collision zone. Tectonophysics $608,366-375$.

Mokhtari, M.A.A., Moinvaziri, H., Ghorbani, M.R., Mehrpartou, M., 2010. Petrology and petrogenesis of Kamtal intrusion, Easter Azerbaijan, NW Iran. Central European Geology 53, 79-96.

Moritz, R., Selby, D., Ovtcharowa, M., Mederer, J., Melkonyan, R., Hovakimyan, S.E., Tayan, R., Popkhadze, N., Gugushvili, V., Ramazanov, V., 2012. Diversity of geodynamic settings during $\mathrm{Cu}, \mathrm{Au}$ and $\mathrm{Mo}$ ore formation in the Lesser Caucasus: new age constraints. Proceedings 1st Triennial European Mineralogy and Crystallography Meeting, Frankfurt, Germany, p. 745.

Moritz R., Mederer, J., Ovtcharova, M., Spikings, R., Selby, D., Melkonyan R., Hovakimyan, S., Tayan R., Ulianov, A., Ramazanov, V., 2013. Jurassic to Tertiary metallogenic evolution of the southernmost Lesser Caucasus, Tethys belt. In : Erik Jonsson et al. (eds), Mineral deposit research for a high-tech world, 12th SGA Biennial Meeting, 12-15 August 2013, Sweden, Uppsala, 3, 1447-1450.

Moritz, R., Noverraz, C., Márton, I., Marchev, P., Spikings, R., Fontignie, D., Spangenberg, J., Vennemann, T., Kolev, K., Hasson, S., 2014. Sedimentary rock-hosted gold deposits of the Tertiary Eastern Rhodopes, Bulgaria : new constraints from the Stremtsi gold prospect. In: Garofalo, P.S. and Ridley, J.R. (eds), Gold-transporting hydrothermal fluids in the Earth's Crust, Special Publication of the Geological Society of London 402, 207-230.

Motaghi, K., Tatar, M., Priestley, K., Romanelli, F., Doglioni, C., Panza, G.F. 2015. The deep structure of the Iranian Plateau. Gondawana Research 28, 407-418.

Movsesyan S.A., Isaenko M. P. (1974). Complex copper-molybdenum deposits. Moskva, "Nedra" publisher, 344 p. (in Russian).

Müntener, O., Kelemen, P., Grove, T.L., 2001. The role of $\mathrm{H}_{2} \mathrm{O}$ during crystallization of primitive arc magmas under uppermost mantle conditions and genesis of igneous pyroxenites. An experimental study: Contributions to Mineralogy and Petrology 141, 643-658.

Nabatian, G., Ghaderi, M., Neubauer, F., Honarmand, M., Liu, X., Dong, Y., Jiang, S.-Y., von Quadt, A., Bernroider, F., 2014. Petrogenesis of Tarom high-potassic granitoids in the AlborzAzarbaijan belt, Iran: Geochemical, $\mathrm{U}-\mathrm{Pb}$ zircon and $\mathrm{Sr}-\mathrm{Nd}-\mathrm{Pb}$ isotopic constraints. Lithos 184-187, 324-345.

Oberhänsli, R., Candan, O., Bousquet, R., Rimmele, G., Okay, A., Goff, J., 2010. Alpine HP evolution of the eastern Bitlis complex, SE Turkey. In: Sosson, M., Kaymakci, N., Stephenson, R.A., Bergerat, F., \& Starostenko, V. (eds) Sedimentary basin tectonics from the Black Sea and Caucasus to the Arabian platform. Geological Society London, Special publication 340, 461483.

Okay, A.I., Zattin, M., Cavazza, W., 2010. Apatite fission-track data for the Miocene Arabia-Eurasia collision. Geology 38, 35-38.

Omrani, J., Agard, P., Whitechurch, H., Benoit, M., Prouteau, G., Jolivet, L., 2008. Arc magmatism and subduction history beneath the Zagros Mountains, Iran: a new report of adakites and geodynamic consequences. Lithos 106, 380-398. 
Pang, K.-N., Chung, S.-L., Zarrinkoub, M.H., Lin, Y.-C., Lee, H.-Y., Lo, C.-H., Khatib, M.M., 2013. Iranian ultrapotassic volcanism at 11 Ma signifies the initiation of postcollisional magmatism in the Arabia-Eurasia collision zone. Terra Nova 25, 405-413.

Pearce, N.J., Perkins, W.T., Westgate, J.A., Gorton, M.P., Jackson, S.E., Neal, C.R., Chenery, S.P., 1997. A compilation of new and published major and trace element data for NIST SRM610 and NIST SRM612 glass reference materials. Geostandards Newsletter 21, 115-144.

Pecerillo, A., Taylor, S.R. 1976. Geochemistry of Eocene calc-alkaline volcanic rocks from the Kastamanou area, northern Turkey. Contributions to Mineralogy and Petrology 58, 63-81.

Perelló, J., Razique, A., Schloderer, J., Asad-Ur-Rehman, 2008. The Chagai porphyry copper belt, Baluchistan province, Pakistan. Economic Geology 103, 1583-1612.

Pettke,T., Oberli, F., Heinrich, C. A., 2010. The magma and metal source of giant porphyry-type ore deposits, based on lead isotope microanalysis of individual fluid inclusions. Earth and Planetary Science Letters 296, 267-277.

Philip, H., Cisternus, A., Gvishiani, A., Gorshkov, A., 1989. The Caucasus: an actual example of the initial stages of a continental collision. Tectonophysics 161, 1-21.

Pijyan, G.O., 1975. Copper-molybdenum formation of the Armenian SSR. Yerevan: Publishing House of the Academy of Sciences Armenian SSR, 311 p. (in Russian).

Pin, C., Briot, D., Bassin, C., Poitrasson, F., 1994. Concomitant separation of strontium and samarium-neodymium for isotopic analysis in silicate samples, based on specific extraction chromatography. Analytica Chimica Acta 298, 209-217.

Planck, T., 2005. Constraints from thorium/lanthanum on sediment recycling at subduction zones and the evolution of the continents. Journal of Petrology 46, 921-944.

Popkhadze , N., Moritz, R., Gugushvili, V., 2014. Architecture of Upper Cretaceous rhyodacitic hyaloclastite at the polymetallic Madneuli deposit, Lesser Caucasus, Georgia. Central European Journal of Geoscience 6, 308-329.

Ramazanov, V.G., Kerimli, U.I., 2012. The formation of gold-quartz-sulphide veins of Pyazbashi deposit and some patters of their distribution. Baku University Publications 2, 124-144 (in Russian with English abstract)

Rapp, R.P., 1995. Amphibole-out phase boundary in partially melted metabasalt, its control over liquid fraction and composition, and source permeability. Journal of Geophysical Research 100, 15601-15610.

Rapp, R.P., Watson, E.B., 1995. Dehydration melting of metabasalt at 8-32 kbar: implications for continental growth and crust-mantle recycling. Journal of Petrology 36, 891-931.

Rapp, R.P., Shimizu, N., Norman, M.D., Applegate, G.S., 1999. Reaction between slab derived melts and peridotite in the mantle wedge: experimental constraints at $3.8 \mathrm{GPa}$. Chemical Geology 160 , $335-356$.

Rezaei-Kahkhaei, M., Galindo, C., Pankhurst, R.J., Esmaeily, D., 2011. Magmatic differentiation in the calc-alkaline Khalkhab-Neshveh pluton, Central Iran. Journal of Asian Earth Sciences 42, 499-514.

Richards, J.P., 2009. Postsubduction porphyry $\mathrm{Cu}-\mathrm{Au}$ and epithermal $\mathrm{Au}$ deposits: products of remelting of subduction-modified lithosphere. Geology 37, 247-250.

Richards, J.P., 2011. High $\mathrm{Sr} / \mathrm{Y}$ arc magmas and porphyry $\mathrm{Cu} \pm \mathrm{Mo} \pm \mathrm{Au}$ deposits: just add water. Economic Geology 106, 1075-1081.

Richards, J.P. 2015. Tectonic, magmatic, and metallogenic evolution of the Tethyan orogen: From subduction to collision. Ore Geology Reviews 70, 323-345.

Rolland, Y., Billo, S., Corsini, M., Sosson, M., Galoyan, G., 2009a. Blueschists of the AmassiaStepanavan Suture Zone (Armenia): linking Tethys subduction history from E-Turkey to W-Iran. International Journal of Earth Science 98, 533-550.

Rolland, Y., Galoyan, G., Bosch, D., Sosson, M., Corsini, M., Fornari, M., Vérati, C., 2009b. Jurassic Back-arc and hot-spot related series in the Armenian ophiolites - implications for the obduction process. Lithos 112, 163-187. 
Rolland, Y., Galoyan, G., Sosson, M., Melkonyan, R., Avagyan, A., 2010. The Armenian ophiolite: insights for Jurassic back-arc formation, Lower Cretaceous hot spot magmatism and Upper Cretaceous obduction over the South Armenian Block In: Sosson, M., Kaymakci, N., Stephenson, R.A., Bergerat, F., \& Starostenko, V. (eds) Sedimentary basin tectonics from the Black Sea and Caucasus to the Arabian platform. Geological Society London, Special publication 340, 353-382.

Rolland, Y., Sosson, M., Adamia, Sh., Sadradze, N., 2011. Prolonged Variscan to Alpine history of an active Eurasian margin (Georgia, Armenia) revealed by ${ }^{40} \mathrm{Ar} /{ }^{39} \mathrm{Ar}$ dating. Gondwana Research 20,798-815.

Rolland, Y., Perincek, D., Kaymakci, N., Sosson, M., Barrier, E., Avagyan, A., 2012. Evidence for $\sim 80-75$ Ma subduction jump during Anatolide-Tauride-Armenian block accretion and $48 \mathrm{Ma}$ Arabia-Eurasia collision in Lesser Caucasus-East Anatolia. Journal of Geodynamics 56-57, 7685.

Saintot, A., Brunet, M.-F., Yakovlev, F., Sébrier, M., Stephenson, R., Ershov, A., Chalot-Prat, F., McCann, T. 2006. The Mesozoic-Cenozoic tectonic evolution of the Greater Caucasus. In: Gee, D.G., \& Stephenson, R.A. (eds) European Lithosphere Dynamics. Geol. Soc. London Memoirs $32,277-289$.

Sarjoughian, F., Kananian, A., Haschke, M., Ahmadian, J., Ling, W., Zong, K. 2012. Magma mingling and hybridization in the Kuh-e Dom pluton, Central Iran. Journal of Asian Earth Sciences 54-55, 49-63.

Schmitz, M., Schoene, B., 2007. Derivation of isotope ratios, errors and error correlations for U-Pb geochronology using ${ }^{205} \mathrm{~Pb}_{-}{ }^{235} \mathrm{U}-\left({ }^{233} \mathrm{U}\right)$-spiked isotope dilution thermal ionization mass spectrometric data. Geochemistry Geophysics Geosystems 8, 08006.

Sen, C., Dunn, T., 1994. Dehydration melting of a basaltic composition amphibolite at 1.5 and 2.0 GPa: implications for the origin of adakites. Contributions to Mineralogy and Petrology 117, 394-409.

Shafaii Moghadam, H., Ghorbani, G., Zaki Khedr, M., Fazlnia, N., Chiaradia, M., Eyuboglu, Y. Santosh, M., Galindo Francisco, C., Lopez Martinez, M., Gourgaud, A., Arai, S., 2014. Late Miocene K-rich volcanism in the Eslamieh Peninsula (Saray), NW Iran: Implications for geodynamic evolution of the Turkish-Iranian High Plateau. Gondwana Research 26, 1028-1050.

Shafiei, B., Haschke, M., Shahabpour, J. 2009. Recycling of orogenic arc crust triggers porphyry Cu mineralization in Kerman Cenozoic arc rocks, southeastern Iran. Mineralium Deposita 44, 265 283.

Sharp, Z. D., 1992. In situ laser microprobe technique for stable isotope analyses. Isotope Geosciences 101, 3-19.

Shengelia, D.M., Tsutsunava, T.N., Shubitidze, L.G., 2006. New data on structure, composition, and regional metamorphism of the Tsakhkunyats and Akhum-Asrikchai massifs, the Lesser Caucasus. Doklady Earth Sciences 409A, 900-904.

Simakin, A.G., Bindeman, I.N., 2012. Remelting in caldera and rift environments and the genesis of hot, "recycled"' rhyolites. Earth and Planetary Science Letters 337-338, 224-235.

Simmons, V., Moazzen, M., 2015. Re-Os dating of molybdenites from Oligocene $\mathrm{Cu}-\mathrm{Mo}-\mathrm{Au}$ mineralized veins in the Qarachilar area, Qaradagh batholith (northwest Iran): implications for understanding Cenozoic mineralization in South Armenia, Nakhchivan, and Iran. International Geology Review 57, 290-304.

Sinclair, W.D., 2007. Porphyry deposits. In Goodfellow, W.D. (ed.) Mineral Deposits of Canada: A Synthesis of Major Deposit-Types, District Metallogeny, the Evolution of Geological Provinces, and Exploration Methods. Geological Association of Canada, Mineral Deposits Division, Special Publication 5, 223-243.

Singer, D.A., Berger, V.I., Moring, B.C., 2002. Porphyry copper deposits of the world: database, maps, and preliminary analysis. United States Geological Survey Open-File Report 02-268. http://wrgis.wr.usgs.gov/open-file/of02-268. 
Sosson, M., Rolland, Y., Müller, C., Danelian, T., Melkonyan, R., Kekelia, S., Adamia, S., Babzadeh, V., Kangarli, T., Avagyan, A., Galoyan, G., Mosar, J., 2010. Subductions, obduction and collision in the Lesser Caucasus (Armenia, Azerbaijan, Georgia), new insights. In: Sosson, M., Kaymakci, N., Stephenson, R.A., Bergerat, F., \& Starostenko, V. (eds) Sedimentary basin tectonics from the Black Sea and Caucasus to the Arabian platform. Geological Society London, Special publication 340, 329-352.

Streckeisen, A., 1976. To each plutonic rock its proper name. Earth-Science Reviews 12, 133.

Sun, S.-S., McDonough, W.F., 1989. Chemical and isotopic systematics of oceanic basalts: Implications for mantle composition and processes. Geological Society of London Special Publication 42, 313-345.

Tanaka, T., Togashi, S., Kamioka, H., Amakawa, H., Kagami, H., Hamamoto, T., Yuhara, M., Orihashi, Y.,Yoneda, S., Shimizu, H., Kunimaru,T., Takahashi, K., Yanagi,Y., Nakano,T., Fujimaki, H., Shinjo, R., Asahara, Y., Tanimizu, M., Dragusanu, C., 2000. JNdi-1: a neodymium isotopic reference in consistency with La Jolla neodymium. Chemical Geology 168, 279-281.

Tayan, R.N., 1984. The feature evolution of fractures of Kadjaran ore field. Proceedings of the National Academy of Sciences of the Republic of Armenia 37, 21-29 (in Russian with English abstract).

Tayan, R.N., 1998. On central magma-ore controlling zone of the Zangezour ore region. Proceedings of the National Academy of Sciences of the Republic of Armenia 51, 20-26 (in Russian with English abstract).

Tayan, R.N., Plotnikov, E.P., Abdurakhmanov, R.U., 1976. Some features of emplacement of geological structure of the Zangezour-Nakhichevan region of Lesser Caucasus. Proceedings of the National Academy of Sciences of the Republic of Armenia 29, 12-20 (in Russian).

Tayan, R.N., Harutunyan, M.A., Hovhannisyan, A.E., 2005. To the problem of dislocation of coppermolybdenum and gold-polymetallic formations in southern Zangezour and opportunities for small ore deposits identification through elements-admixtures in pyrites. Proceedings of the National Academy of Sciences of the Republic of Armenia 58, 17-24 (in Russian with English abstract).

Todt, W., Cliff, R.A., Hanser, A., Hofmann, A.W., 1996. Evaluation of a ${ }^{202} \mathrm{~Pb}-{ }^{205} \mathrm{~Pb}$ double spike for high-precision lead isotope analysis. In: Basu, A., Hart, S. (Eds.), Earth Processes: Reading the Isotopic Code, American Geophysical Union, Washington, Geophysical Monograph 95, 429437.

Tulloch, A. J., Kimbrough, D.L., 2003. Paired plutonic belts in convergent margins and the development of high $\mathrm{Sr} / \mathrm{Y}$ magmatism: Peninsular Range batholith of California and Median batholith of New Zealand. Geological Society of America Special Paper 374, 275-295.

Verdel, C., Wernicke, B.P., Hassanzadeh, J., Guest B., 2011. A Paleogene extensional arc flare-up in Iran. Tectonics 30, TC3008.

Vincent, S.J., Allen, M.B., Ismail-Zadeh, A.D., Flecker, R., Foland, K.A., Simmons, M.D., 2005. Insights from the Talysh of Azerbaijan into the Paleogene evolution of the South Caspian region. Geological Society of America Bulletin 117, 1513-1533.

Von Quadt, A., Moritz, R., Peytcheva, I., Heinrich, C. A., 2005. Geochronology and geodynamics of Upper Cretaceous magmatism and $\mathrm{Cu}-\mathrm{Au}$ mineralization in the Panagyurishte region of the Apuseni-Banat-Timok-Srednogorie belt (Bulgaria). Ore Geology Reviews 27, 95-126

Wang, G., Wyman, D.A., Xu, J.-F., Zhao, Z.-H., Jian, P., Xiong, X.-L., Bao, Z.-W., Li, C.-H., Bai, Z.H., 2006. Petrogenesis of Cretaceous adakitic and shoshonitic igneous rocks in the Luzong area, Anhui Province (eastern China): Implications for geodynamics and $\mathrm{Cu}-\mathrm{Au}$ mineralization. Lithos 89, 424-446.

Wang, H., Wu, Y.-B., Li, C.-R., Zhao, T.-Y., Qin, Z.-W., Zhu, L.-Q., Gao, S., Zheng, J.-P., Liu, X.-M., Zhou, L., Zhang, Y., Yang, S.-H, 2014. Recycling of sediment into the mantle source of K-rich mafic rocks : Sr-Nd-Hf-O isotopic evidence from the Fushui complex in the Qinling orogen. Contributions to Mineralogy and Petrology 168, 1062.

Wasserburg, G., Jacousen, S., DePaolo, D., McCulloch, M., Wen, T., 1981. Precise determination of $\mathrm{Sm} / \mathrm{Nd}$ ratios, $\mathrm{Sm}$ and $\mathrm{Nd}$ isotopic abundances in standard solutions. Geochimica et Cosmochimica Acta 45, 2311-2323. 
Watts, K.E., Bindeman, I.N., Schmitt, A.K., 2011. Large-volume rhyolite genesis in caldera complexes of the Snake River plain: Insights from the Kilgore tuff of the Heise volcanic field, Idaho, with comparison to Yellowstone and Bruneau-Jarbidge rhyolites. Journal of Petrology 52, 857-890.

Wendt, I., Carl, C., 1991. The statistical distribution of the mean squared weighted deviation. Chemical Geology, Isotope Geoscience Section 86, 275-285.

Woodhead, J.D., Hergt, J.M., Davidson, J.P. Eggins, S.M., 2001. Hafnium isotope evidence for 'conservative' element mobility during subduction zone processes, Earth and Planetary Science Letters 192, 331-346.

Yeganehfar, H., Reza Ghorbani, M., Shinjo, R., Ghaderi, M. 2013. Magmatic and geodynamic evolution of Urumieh-Dokhtar basic volcanism, Central Iran: major, trace element, isotopic, and geochronologic implications. International Geological Review 55, 767-786.

Yilmaz, A., Adamia, S., Chabukiani, A., Chkhotua, T., Erdogan, K., Tzucu, S., Karabiyikoglu, M., 2000. Structural correlation of the southern Transcaucasus (Georgia)-eastern Pontides (Turkey). In: Bozkurt, E., Winchester, J.A., \& Piper, J.D.A. (eds) Tectonics and magmatism in Turkey and the surrounding area. Geological Society London, Special publication 173, 171-182.

Yigit, O., 2009. Mineral deposits of Turkey in relation to Tethyan metallogeny: Implications for future mineral exploration. Economic Geology 104, 19-51.

Zakariadze, G.S., Dilek, Y., Adamia, S.A., Oberhänsli, R.E., Karpenko, S.F., Bazylev, B.A., Solov'eva, N., 2007. Geochemistry and geochronology of the Neoproterozoic Pan-African Transcaucasian Massif (Republic of Georgia) and implications for island arc evolution of the late Precambrian Arabian-Nubian shield. Gondwana Research 11, 92-108.

Zamani, G. B., Masson, F., 2014. Recent tectonics of East (Iranian) Azerbaijan from stress state reconstructions. Tectonophysics $611,61-82$.

Zartman, R.E., Doe, B.R., 1981. Plumbotectonics - The model. Tectonophysics 75, 135-162.

Zheng, T. Y., L. Zhao, L., Xu, W. W., Zhu, R. X. 2008. Insight into modification of North China Craton from seismological study in the Shandong Province. Geophysical Research Letters 35, L22305.

Zindler, A., Hart, S., 1986. Chemical geodynamics. Annual Review of Earth and Planetary Sciences $14,493-571$.

Zonenshain, L.P., Le Pichon, X., 1986. Deep basins of the Black Sea and Caspian Sea as remnants of Mesozoic back-arc basins. Tectonophysics 123, 181-211. 


\section{Figure captions}

Figure 1. Geological map from eastern Turkey to Iran highlighting the Lesser Caucasus area. From Mederer et al. (2014), and additional information from Azizi and Moinevaziri (2009), Hässig et al. (2013a, b) and Zamani and Masson (2014). The Lesser Caucasus consists of the Somkheto-Karabagh belt along the Eurasian margin, the ophiolites of the Sevan-Akera suture zone and the South Armenian block. The South Armenian block and the Eastern Anatolian platform are of Gondwanian origin. Location of Figure 3a is centred on the ZangezurOrdubad region in the southernmost Lesser Caucasus, which hosts the composite MeghriOrdubad and Bargushat plutons. Tectonic zones and faults: ABV - Artvin-Bolnisi volcanicarc; IAES - Izmir-Ankara-Erzinkan suture; KGF - Khustup-Giratagh fault; KP - Kapan block; MOP - Meghri-Ordubad pluton of the Zangezur-Ordubad region; SSF - sublatudinal strike slip fault (based on Hässig et al., 2013a, and previously suggested by Kazmin et al., 1986, and Gabriyelyan et al., 1989). Major ore districts, deposits and prospects: A - Alaverdi district (including the Alaverdi, Shamlugh and Akhtala deposits); Am - Amulsar epithermal prospect; B - Bolnisi district (including the Madneuli, Sakdrisi and Beqtakari deposits); C Chovdar epithermal deposit; D - Dashkasan iron skarn deposit; G - Gedabek district (including the Gedabek, Khar Khar, Kharadagh, and Bitibulak deposits and prospects); Go Gosha epithermal deposit; K - Kapan district (including the Shahumyan, Centralni west and east deposits); $\mathrm{M}$ - Mehmana district; Me - Merisi district; Mg - Meghradzor epithermal prospect; T - Teghut porphyry deposit; Z - Zod-Sotk epithermal deposit; ZO - ZangezurOrdubad district (see Fig. 3b). Location of areas selected for the comparison of the geochemistry of Cenozoic magmatic rocks in Figures 22 and 23: I - Miocene rocks from the central Lesser Caucasus (Dilek et al., 2009), II - Eocene rocks from the Talysh basin (Vincent et al., 2005), III - Eocene to Oligocene rocks from western Alborz (Aghazadeh et al., 2010, 2011; Asiabanha and Foden, 2012; Castro et al., 2013), IV - Eocene rocks from central Alborz (Verdel et al., 2011), V - Eocene to Mio-Pliocene rocks from the northern UrumiehDokhtar belt (Omrani et al., 2008; Rezaei-Kahkhaei et al., 2011; Sarjoughian et al., 2012; Yeganehfar et al., 2013; Honarmand et al., 2014).

Figure 2. Geodynamic reconstruction of the Tethyan belt centred on the Lesser Caucasus (LCR) for Late Maastrichtian (a), Ypresian (b), Lutetian (c), Rupelian (d) and Early Burdigalian (e) times (modified from Barrier and Vrielynck, 2008). Orange-filled black circle indicates location of the composite Meghri-Ordubad and Bargushat plutons of the ZangezurOrdubad region. ABV - Artvin-Bolnisi volcanic-arc; AR - Alborz range; ATB - AdjaraTrialeti basin; BFB - Balkan fold-belt; BPM - Bitlis-Pütürge massif; EAP - Eastern Anatolian platform (including the South Armenian block in its eastern extremity); GCB Great Caucasus basin; GKF - Great Kevir fault; IAM - Izmir-Ankara-Erzinkan massif; KOM - Khoy ophiolite massif; KON - Khoy ophiolite nappe; LCR - Lesser Caucasus range; MeM 
- Menderes massif; MeP - Menderes platform; MsO - Mesogea ocean; MZT - Main Zagros thrust; NAM - North Anatolian massif; PAM - Peri-Arabian massif; PoR - Pontides range; RSM - Rhodopes-Srandja massif; SAM - Sevan-Akera ophiolitic massif; SCB - SouthCaspian basin; SFB - Srednogorie fold-belt; SrB - Sirjan block; SSB - Sanandaj-Sirjan block; TaP - Taurus platform; UDV - Urumieh-Dokhtar volcanic-arc; ZDF - Zagros deformation front (all abbreviations and domain names from Barrier and Vrielynck, 2008).

Figure 3. a - Simplified geological map of the Zangezur-Ordubad region and the Kapan block of the southernmost Lesser Caucasus, and northern Iran (from Mederer et al., 2013, 2014), A - Agarak deposit; D - Dastakert deposit; K - Kadjaran deposit; P - Paragachay deposit; KGF: Khustup-Giratakh fault. Location of Araks fault after Zamani and Masson (2014). See Figure 1 for location of Figure 3a. b - Simplified geological map of the composite Meghri-Ordubad and Bargushat plutons, including major ore deposits and prospects of the Zangezur-Ordubad region (after Tayan et al., 1976, 2005; Babazadeh et al., 1990). The Re-Os ages obtained for molybdenites are indicated next to the dated porphyries (Dastakert, Hankasar, Kadjaran, Paragachay, Aygedzor and Agarak; see Moritz et al., 2013). The Zangezur and Nakhitchevan blocks belong to the South Armenian block of Gondwanian origin. Only the major faults are included, the abundant subsidiary faults have been omitted for the sake of clarity. Sample locations for U-Pb zircon dating (see Table 5 and Figure 18): 1 - KJ-12-11A (Kadjaran open pit); 2 - KJ-10-02 (near Atkis); 3 - KJ-12-07 (Meghri ridge); 4 - LI-10-03 (Lichk area); 5 - AG-10-06A and AG-10-07 (east of Agarak deposit).

Figure 4. Summary of major magmatic and ore-forming events within the composite MeghriOrdubad and Bargushat plutons of the Zangezur-Ordubad region, Lesser Caucasus, including in blue the new high precision TIMS U-Pb dating of magmatic rocks described in this study, and comparison with major, regional tectonic and magmatic events during Arabia-Eurasia convergence recorded in the Lesser Caucasus, the Talysh basin in Azerbaijan, and Iran. Source of data and interpretations: 1 - Djrbashyan et al. (1976); 2 - K-Ar whole rock age from Ghukasyan (1966); 3, 4, 5 - Rb-Sr isochron ages, respectively, by Ghukasyan et al. (2006), and Melkonyan et al. (2008, 2010); 6 - New high precision U-Pb TIMS dating of magmatic zircons (this study); 7 - Tayan et al. (1976); 8 - Re-Os molybdenite age (Moritz et al., 2013); 9 - K-Ar sericite age (Bagdasaryan et al., 1969); 10 - Roland et al. (2009b); 11 Roland et al. (2010); 12 - Oberhänsli et al. (2011); 13 - Rolland et al. (2012); 14 - McQuarrie et al. (2003); 15 - Ballato et al. (2011); 16 - Vincent et al. (2005); 17 - Allen and Armstrong (2008); 18 - McQuarrie and van Hinsbergen (2013); 19 - Okay et al. (2010). 
Figure 5. Metal grades and tonnages of porphyry $\mathrm{Cu}-\mathrm{Mo}$ deposits from the ZangezurOrdubad region, Lesser Caucasus (see details of deposits in Table 1 and location in Figure $3 b$ ) compared with porphyry deposits from other parts of the world. a - Copper grades vs. tonnage; $\mathrm{b}$ - Molybdenum grades vs. tonnage $\mathrm{c}$ - Molybdenum vs copper grades, and $\mathrm{Au}$ grades when available. Fields of copper and molybdenum grades and tonnages of different types of porphyry deposits $(\mathrm{Cu}, \mathrm{Cu}-\mathrm{Mo}, \mathrm{Mo}, \mathrm{Cu}-\mathrm{Au}, \mathrm{Au})$ from other parts of the world after Sinclair (2007). Two data sources exist for metal grades and tonnages at Kadjaran: grades and tonnage of Kadjaran* are from the local Armenian mine staff, and grades and tonnage of Kadjaran** are from Singer et al. (2002).

Figure 6. a - TAS classification of magmatic rocks (Le Maître, 2002) including names of equivalent names for coarse-grained intrusive rocks (Middlemost, 1994). b-QAPF diagram (Streckeisen, 1976). $\mathbf{c}-\mathrm{K}_{2} \mathrm{O}$ (wt\%) vs $\mathrm{SiO}_{2}$ (wt\%) diagram (Pecerillo and Taylor, 1976).

Figure 7. Petrographic features of representative magmatic rocks from the composite MeghriOrdubad pluton. See detailed petrographic descriptions and locations in Table 3 and Figure $3 b$. a - Equigranular Eocene granodiorite from the Agarak area with quartz, plagioclase and Kfeldspar (sample AG-10-03). b - Equigranular Eocene granite from the Agarak area with quartz, plagioclase, amphibole, and subsidiary biotite and K-feldspar (sample AG-10-07, dated at $44.03 \mathrm{Ma}$ see Table 5 and Figure 18). c - Eocene porphyritic trachybasalt from the Agarak area with plagioclase phenocrysts in a plagioclase-pyroxene matrix (sample AG-1004). d - Equigranular Oligocene hornblende gabbro from the Meghri ridge with resorbed pyroxene surrounded by amphibole, plagioclase, biotite and subsidiary apatite (sample KJ-1207, dated at $33.49 \mathrm{Ma}$ see Table 5 and Figure 18). e - Equigranular Oligocene monzonite sampled east of the Kadjaran-Atkis area, with myrmekitic K-feldspar, plagioclase and amphibole surrounding cores of pyroxene (sample KJ-10-06A). f - Equigranular Miocene granite sampled along Katudjur river, west of Kadjaran, with quartz, K-feldspar, plagioclase, amphibole, and subsidiary biotite and sphene (sample KJ-09-02). g - Porphyritic Miocene monzonite sampled along the Vogchi section, along the road from Kadjaran to Kapan, with phenocrysts of plagioclase, amphibole, biotite and quartz in an aphanitic matrix (sample KJ09-04B). h - Porphyritic Pliocene dacite near Lichk area, with phenocrysts of plagioclase, amphibole, and biotite and quartz in a microcrystalline quartz-plagioclase (sample LI-10-04). Abbreviations: amph - amphibole; ap - apatite; bt - biotite; kfs - K-feldspar; plag plagioclase; px - pyroxene; tit - sphene; qtz - quartz.

Figure 8. Representative major element Harker diagrams. High- and low-silica adakite fields in Figure 8g from Martin et al. (2005).

Figure 9. Representative trace element Harker diagrams. Same symbols as in Figure 8. 
Figure 10. Primitive, mantle-normalized extended trace element spider diagrams. Normalization with respect to Sun and McDonough (1989).

Figure 11. Rare Earth element chondrite-normalized diagrams. Normalization with respect to Sun and McDonough (1989).

Figure 12. a - $(\mathrm{La} / \mathrm{Yb})_{\mathrm{n}}$ and $(\mathrm{Dy} / \mathrm{Yb})_{\mathrm{n}}$ diagram with normalization with respect to Sun and McDonough (1989). b - Eu*/Eu vs $\mathrm{SiO}_{2}$ (wt\%) diagram depicting europium anomalies.

Figure 13. a-d - $\mathrm{Sr} / \mathrm{Y}$ vs $\mathrm{Y}(\mathrm{ppm}), \mathrm{La} / \mathrm{Yb}$ vs $\mathrm{Yb}(\mathrm{ppm}), \mathrm{Sr} / \mathrm{Y}$ vs $\mathrm{SiO}_{2}(\mathrm{wt} \%)$ and $\mathrm{La} / \mathrm{Yb}$ vs $\mathrm{SiO}_{2}(\mathrm{wt} \%)$ discrimination plots.

Figure 14. $\mathrm{Nd}$ and $\mathrm{Sr}$ isotopic compositions of magmatic whole rock samples from the Meghri-Ordubad pluton, and comparison with magmatic rocks from the Kapan block (Fig. 3) and Cenozoic Iranian magmatic arcs. $\mathrm{b}$ is a detailed view of a. $\mathrm{Nd}$ and $\mathrm{Sr}$ initial isotopic ratios of magmatic rocks from the Meghri-Ordubad pluton, Lesser Caucasus, compared to initial isotopic compositions of Cenozoic magmatic rocks from the Alborz and Urumieh-Dokhtar ranges in Iran, and the Turkish-Iranian high plateau and Sanandaj-Sirjan range, Iran. All isotope data were age-corrected to account for $\mathrm{Rb}$ and $\mathrm{Sm}$ decay. Oceanic mantle endmember fields (HIMU, EM1, EM2) are from Zindler and Hart (1986). The present-day CHUR and bulk Earth UR are from Wasserburg et al. (1981) and DePaolo (1988), respectively. Black diamonds with grey filling: Eocene Urumieh-Dokhtar rocks from Omrani et al. (2008). References in brackets next to the compositional fields: 1 - Ahmadian et al. (2009), 2 - Aghazadeh et al. (2011), 3 - Asiabanha and Foden (2012), 4 - Azizi et al. (2014), 5 - Haschke et al. (2010), 6 - Honarmand et al. (2014) , 7 - Nabatian et al. (2014), , 8 - Omrani et al. (2008), , 9 - Pang et al. (2013), 10 - Rezaei-Kahkhaei et al. (2011), 11 - Sarjoughian et al. (2012), 12 - Shafaii Moghadam et al. (2014), 13 - Shafiei et al. (2009), 14 - Yeganehfar et al. (2013).

Figure 15. a - Initial ${ }^{87} \mathrm{Sr} /{ }^{86} \mathrm{Sr}$ vs $1 / \mathrm{Sr}(1 / \mathrm{ppm})$. b - Initial ${ }^{143} \mathrm{Nd} /{ }^{144} \mathrm{Nd}$ vs $1 / \mathrm{Nd}(1 / \mathrm{ppm})$.

Figure 16. Lead isotopic compositions of magmatic whole rock samples from the MeghriOrdubad pluton and comparison with Iranian Cenozoic magmatic arcs. The isotope data were age-corrected to account for $U$ and Th decay. UD: Urumieh-Dokhtar belt. Light blue compositional fields: Eocene Alborz and Urumieh-Dokhtar from Honarmand et al. (2014) and Nabatian et al. (2014). Light orange Oligocene and light green Miocene compositional fields: from Yeganehfar et al. (2013) and Honarmand et al. (2014). Upper crust and orogene lead isotopic evolution curves generated by the plumbotectonics model of Zartman and Doe (1981).

Figure 17. Oxygen isotopic compositions of magmatic whole rock samples from the MeghriOrdubad and Bargushat plutons plotted against $\mathrm{Th} / \mathrm{Nb}$. The typical $\delta^{18} \mathrm{O}$ range of $5.5 \% \pm$ $0.2 \%$ (V-SMOW) of mantle peridotites is from Eiler (1991) and Mattey et al. (1994). 
Figure 18. Concordia diagrams and ${ }^{206} \mathrm{~Pb} /{ }^{238} \mathrm{U}$ age plots with $\mathrm{U}-\mathrm{Pb}$ dates of weighted mean clusters of zircon samples from the Meghri-Ordubad and Bargushat plutons.

Figure 19. a $-\mathrm{Dy} / \mathrm{Yb}$ vs $\mathrm{SiO}_{2}(\mathrm{wt} \%)$ diagram of magmatic whole rock samples from the Meghri-Ordubad and Bargushta plutons, and displaying amphibole and garnet fractionation trends according to Davidson et al. (2007). b - La/Sm vs $\mathrm{Sm} / \mathrm{Yb}$ displaying approximate stability thresholds of clinopyroxene, amphibole and garnet stabilities in mantle melt residues according to Kay and Mpodozis (2001), Haschke et al. (2006), Shafiei et al. (2009) and Mamani et al. (2010). CPx: clinopyroxene; Amph: amphibole; Gn: garnet. Source enrichment and increasing pressure trends from Shafiei et al. (2009). c and d $-\mathrm{Sr} / \mathrm{Y}$ and $\mathrm{Y}(\mathrm{ppm})$ vs age diagram displaying variations attributed to progressive differences in pressure differentiation. The ages quoted in $\mathrm{c}$ and $\mathrm{d}$ were obtained in this study for the successive magmatic events by $\mathrm{U}-\mathrm{Pb}$ TIMS dating of zircons (see Figure 18 and Table 5). The depicted porphyry Cu-Mo events are: the first porphyry event at 40-44 Ma, during Eocene subduction of the Neotethys (Figs 4 and 21), including the Agarak, Hankasar, Aygedzor and Dastakert deposits (Table 1), and the second porphyry event at 26-27 Ma, during Oligocene collision to post-collision evolution of the Zangezur-Ordubad region (Figs 4 and 21), including the Kadjaran and Paragachay deposits (Table 1).

Figure 20. a - Ba (ppm) vs Nb/Y diagram of magmatic whole rock samples from the MeghriOrdubad pluton, and displaying variable fluid- and melt-related enrichment in subduction settings (from Kepezhinskas et al., 1977). b - Th/Yb vs Ba/La diagram displaying variable fluid- and melt-related enrichment in subduction settings (from Woodhead et al., 2001). c ${ }^{206} \mathrm{~Pb} /{ }^{204} \mathrm{~Pb}$ correlation with $\mathrm{Th} / \mathrm{Nb}$. d $-\mathrm{SiO}_{2}(\mathrm{wt} \%)$ variation with respect to $\mathrm{Mg \#}(100 *$ $\left.\mathrm{Mg} /\left(\mathrm{Mg}+\mathrm{Fe}^{2+}\right)\right)$ of magmatic whole rock samples from the Meghri-Ordubad pluton. Experimental melt fields from Kamvong et al. (2014): experimental basalt melt field at 1-4 GPa from Rapp (1995), Rapp and Watson (1995) and Sen and Dunn (1994), and experimental hybrid melts from Rapp et al. (1999).

Figure 21. Cenozoic evolution of the Zangezur-Ordubad region, southernmost Lesser Caucasus, and progressive construction of the composite Meghri-Ordubad and Bargushat plutons. a - Eocene subduction: converging tectonics between Arabia and the amalgamated terranes along the Eurasian margin, including the Eastern Anatolian platform, the South Armenian block, and the Jurassic-Cretaceous Kapan block. The Zangezur-Ordubad region is bounded by the Ordubad-Salvard and the Khustup-Giratagh faults at the contact between the South Armenian block and the Kapan block. Eocene evolution is characterized by calcalkaline to high-K calc-alkaline arc magmatism related to subduction of the Neotythys. Slab dehydration dominates the magmatic evolution, and the lithospheric mantle wedge is progressively metasomatised. Small tonnage porphyry $\mathrm{Cu}-\mathrm{Mo}$ deposits were emplaced during arc magmatism, including the Agarak, Hankasar, Aygedzor and Dastakert deposits between 
about 44 and $40 \mathrm{Ma}$ (Fig. 4). b-Arabia-Eurasia collision at the Eocene-Oligocene transition resulted in strong deformation along the accreted terranes, including transpression, with translithospheric faults providing favourable channels for asthenospheric upwelling, increased heat flow. Shoshonitic magmatism during the early Oligocene (32-33 Ma) was sourced by decompression melting of metasomatised lithospheric mantle. c - Late Oligocene to MioPliocene adakitic magmatism originated from a more depleted and more intensely metasomatised lithospheric mantle, and from magmas that underwent fractional crystallization at deeper levels in the crust, possibly due to continuous compression in the collision setting. Adakitic rocks were generated by partial melting of a thickened juvenile lower crust intruded by diapirs of hot metasomatised and depleted lithospheric mantle, or partial foundering and melting of thickened lower crust in the underlying metasomatised and depleted lithospheric mantle. The second and major Oligocene porphyry $\mathrm{Cu}-\mathrm{Mo}$ event resulted in the emplacement of the large tonnage Kadjaran and the Paragachay deposits at about 26-27 Ma, during evolution from early Oligocene high-K calc-alkaline and shoshonitic magmatism to late Oligocene and Mio-Pliocene adakitic magmatism (Fig. 4). Slab roll-back as depicted in $\mathrm{b}$ and $\mathrm{c}$ is possible in the context of the collision tectonics evolution during the Oligo-Miocene, and would have also favoured asthenospheric upwelling.

Figure 22. Comparison of primitive, mantle-normalized extended trace element spider diagrams for magmatic rocks from the composite Meghri-Bergushat plutons from the Zangezur-Ordubad region, Lesser Caucasus, and the Cenozoic Alborz and Urumieh-Dokhtar belts of Iran. Normalization with respect to Sun and McDonough (1989). a Eocene magmatic rocks. b Oligocene magmatic rocks. c Mio-Pliocene magmatic rocks. Meghri-Bergushat plutons compositional fields based on data from this study, see Figure 10. Alborz data: Eocene (35-49 Ma) from Vincent et al. (2005), Verdel et al. (2011), Asiabanha and Foden (2012) and Castro et al. (2013); Oligocene from Aghazadeh et al. (2010, 2011) and Castro et al. (2013). Central Lesser Caucasus data: Miocene ( $\sim 10 \mathrm{Ma})$ from Dilek et al. (2009). Northern Urumieh-Dokhtar data: Eocene from Omrani et al. (2008), Rezaei-Kahkhaei et al. (2011) and Sarjoughian et al. (2012); Oligocene from Yeganehfar et al. (2013); Mio-Pliocene from Omrani et al. (2008), Yeganehfar et al. (2013) and Honarmand et al. (2014). Oceanic island basalt data from Sun and McDonough (1989). See Figure 1 for location of data from Alborz and northern Urumieh-Dokhtar. 
Figure 23. Comparison of data from magmatic rocks of the composite Meghri-Bergushat plutons from the Zangezur-Ordubad region (this study), Miocene rocks from the central Lesser Caucasus, and the Cenozoic Alborz and the northern Urumieh-Dokhtar belts. a and $\mathbf{b}$ - Th/Yb vs Ba/La for Alborz and Urumieh-Dokhtar, respectively. c and d - Ba vs Nb/Y for Alborz and Urumieh-Dokhtar, respectively. e and $\mathbf{f}-\mathrm{La} / \mathrm{Sm}$ vs $\mathrm{Sm} / \mathrm{Yb}$ for Alborz and Urumieh-Dokhtar, respectively. $\mathbf{g}$ and $\mathbf{h}-\mathrm{La} / \mathrm{Y}$ vs Y (ppm) for Alborz and Urumieh-Dokhtar, respectively. Meghri-Bergushat plutons compositional fields based on data from this study, see Figures 13b, 19b and 20a-b. Alborz data: Eocene (35-49 Ma) from Vincent et al. (2005), Verdel et al. (2011), Asiabanha and Foden (2012) and Castro et al. (2013); Lower Oligocene (29-31 Ma) from Aghazadeh et al. (2010, 2011); Upper Oligocene ( 24 Ma) from Aghazadeh et al. (2011) and Castro et al. (2013). Central Lesser Caucasus data: Miocene ( $\sim 10 \mathrm{Ma})$ from Dilek et al. (2009). Urumieh-Dokhtar data: Eocene (including 38 and $47 \mathrm{Ma}$ ) from Omrani et al. (2008), Rezaei-Kahkhaei et al. (2011) and Sarjoughian et al. (2012); Lower Oligocene (27 $\mathrm{Ma}$ ) from Yeganehfar et al. (2013); Lower Miocene (18-21 Ma) from Yeganehfar et al. (2013) and Honarmand et al. (2014); Mio-Pliocene from Omrani et al. (2008). See Figure 1 for location of data from Alborz and northern Urumieh-Dokhtar. 


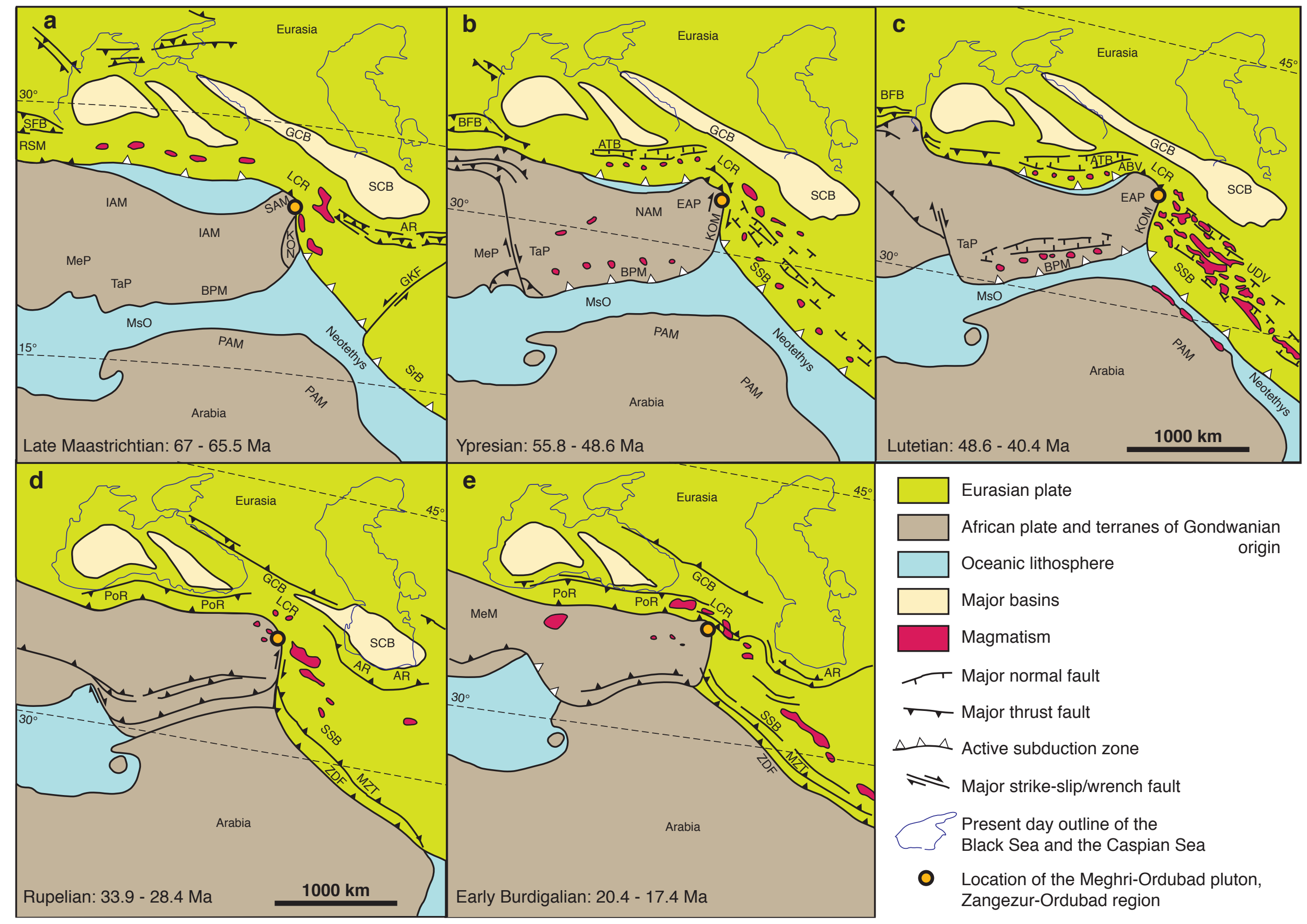

Fig. 2 


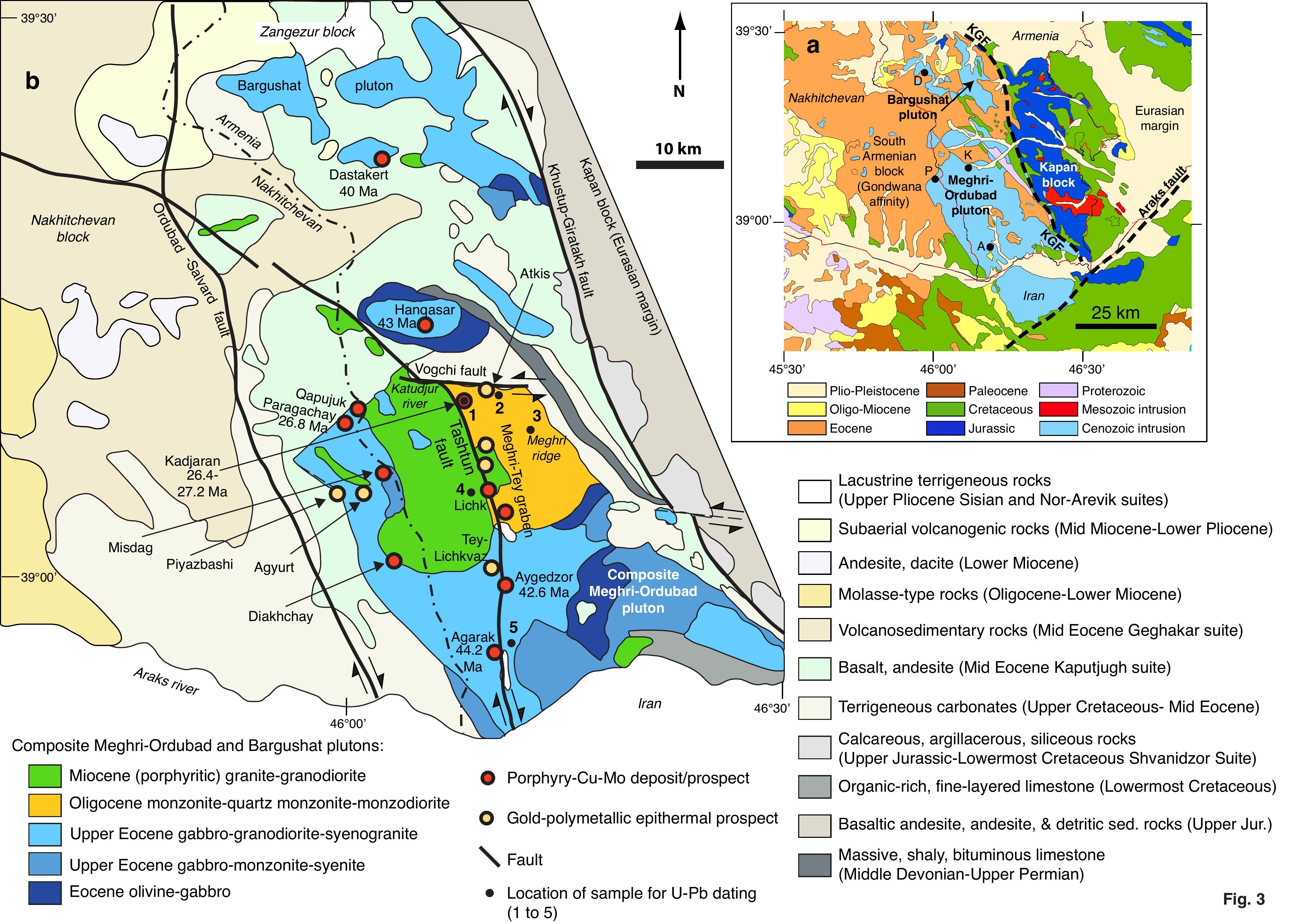




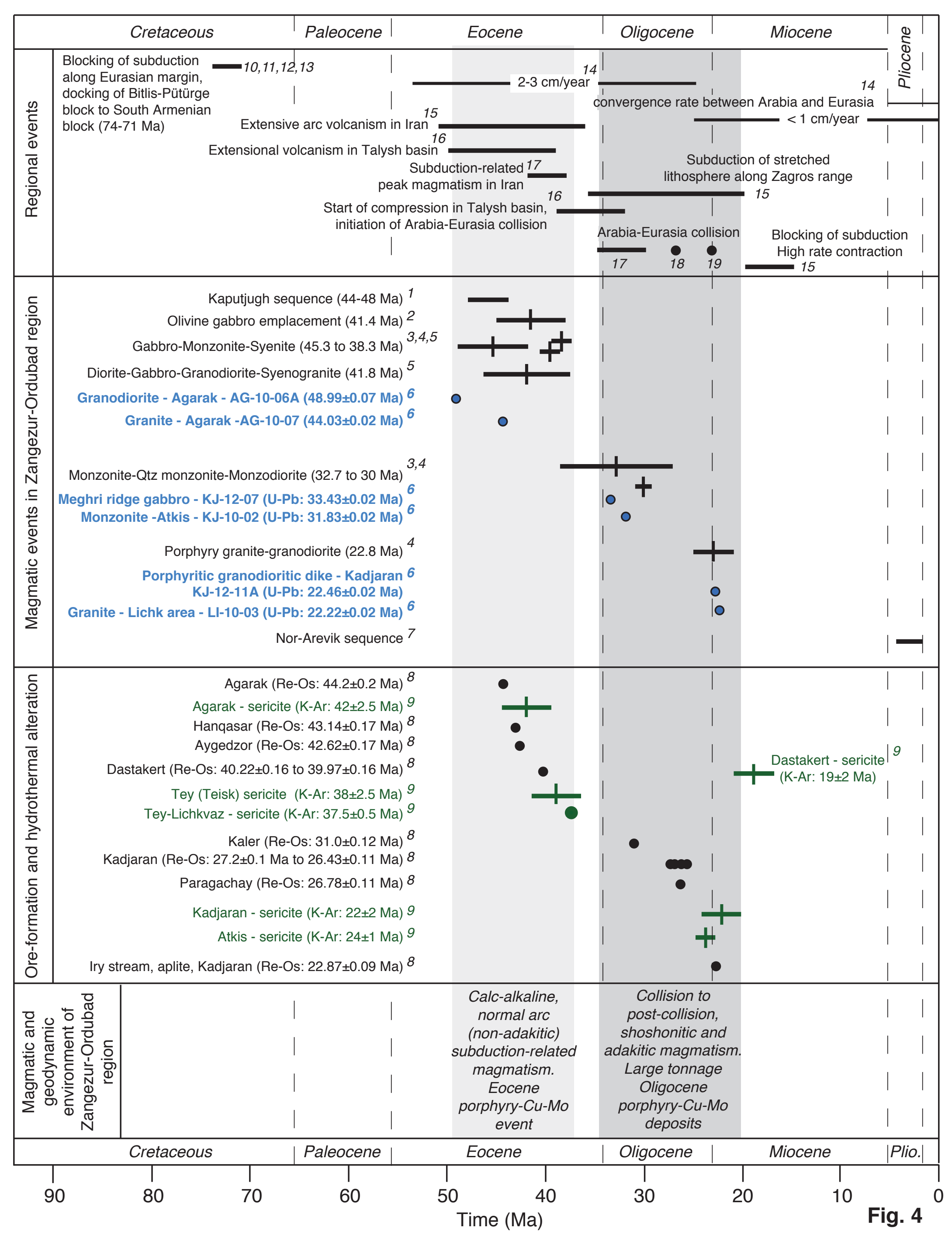



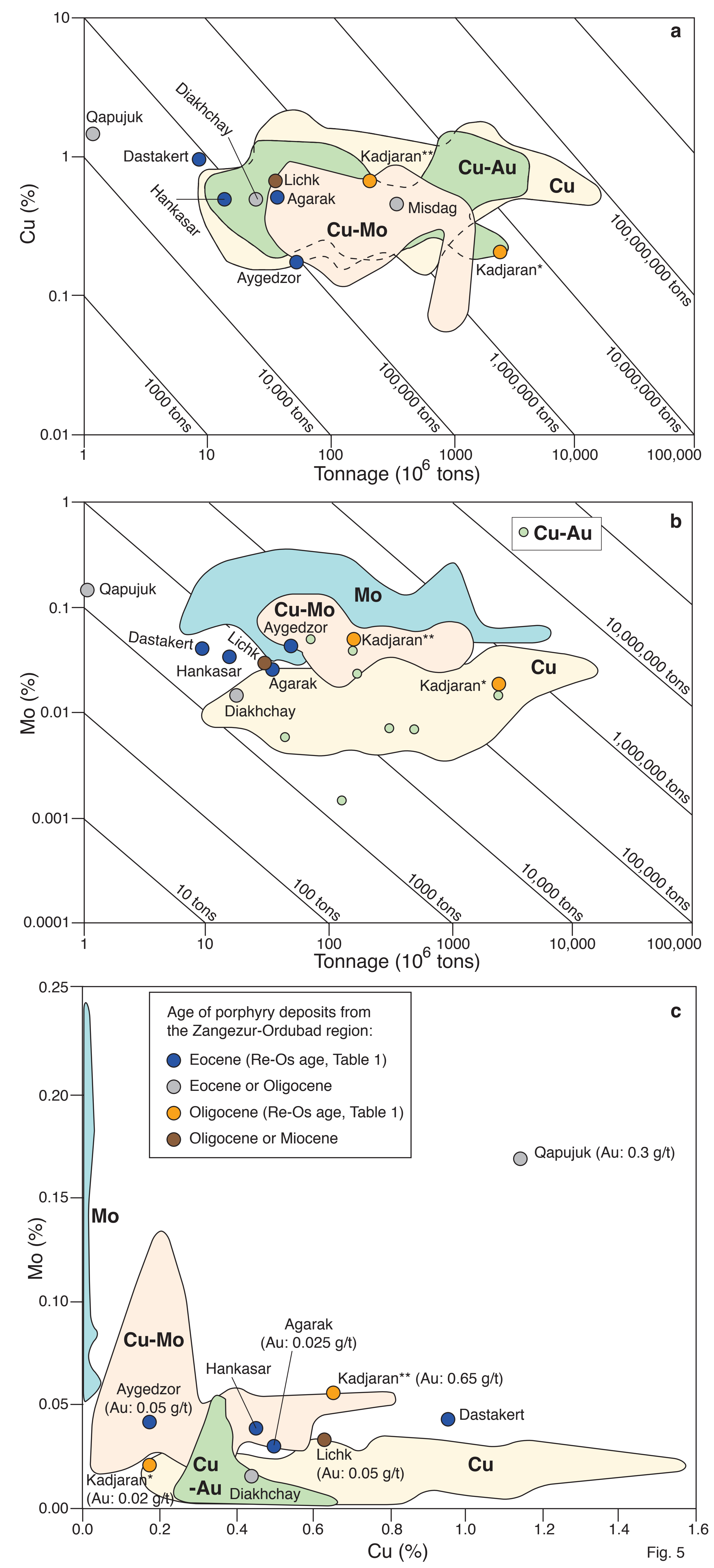

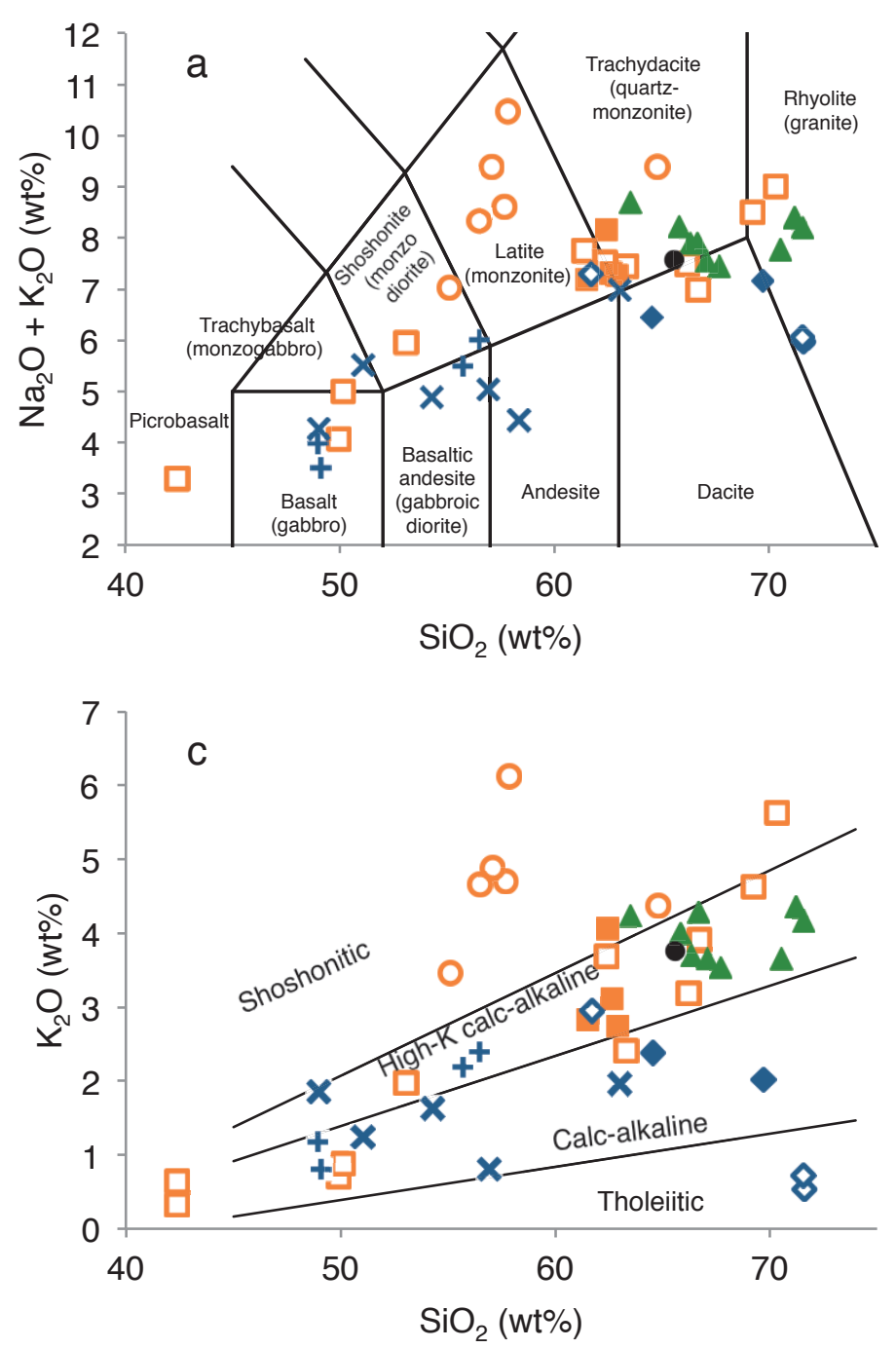

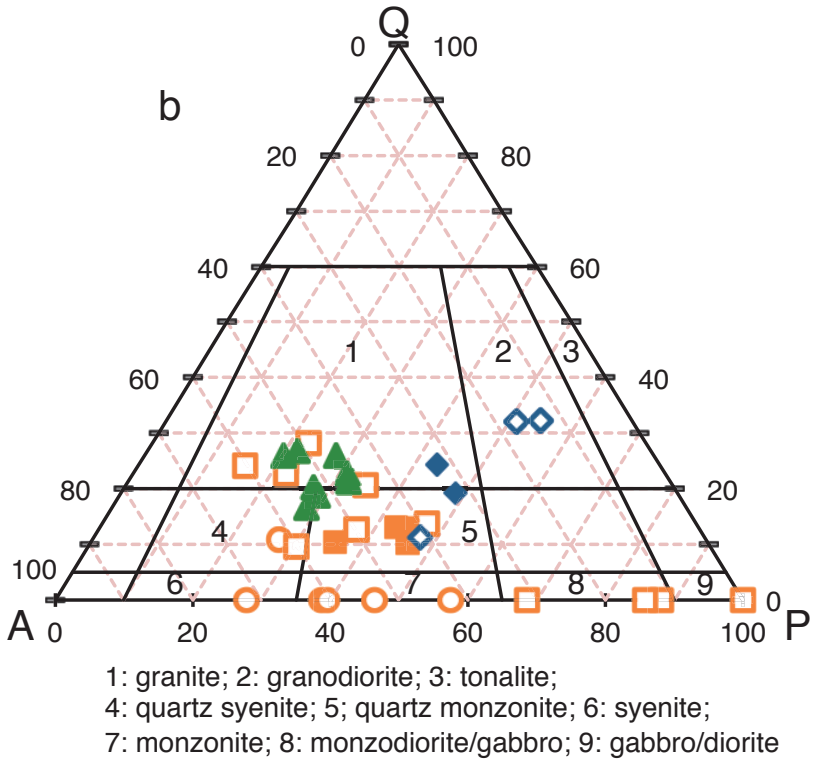

$\diamond$ Eocene normal arc

* Eocene mafic, normal arc

+ Eocene Kapan block (Mederer et al., 2013)

- Eocene adakitic-like

$\square$ Oligocene

O Oligocene shoshonitic

- Oligocene adakitic

$\triangle$ Miocene adakitic

- Pliocene adakitic

Fig. 6 


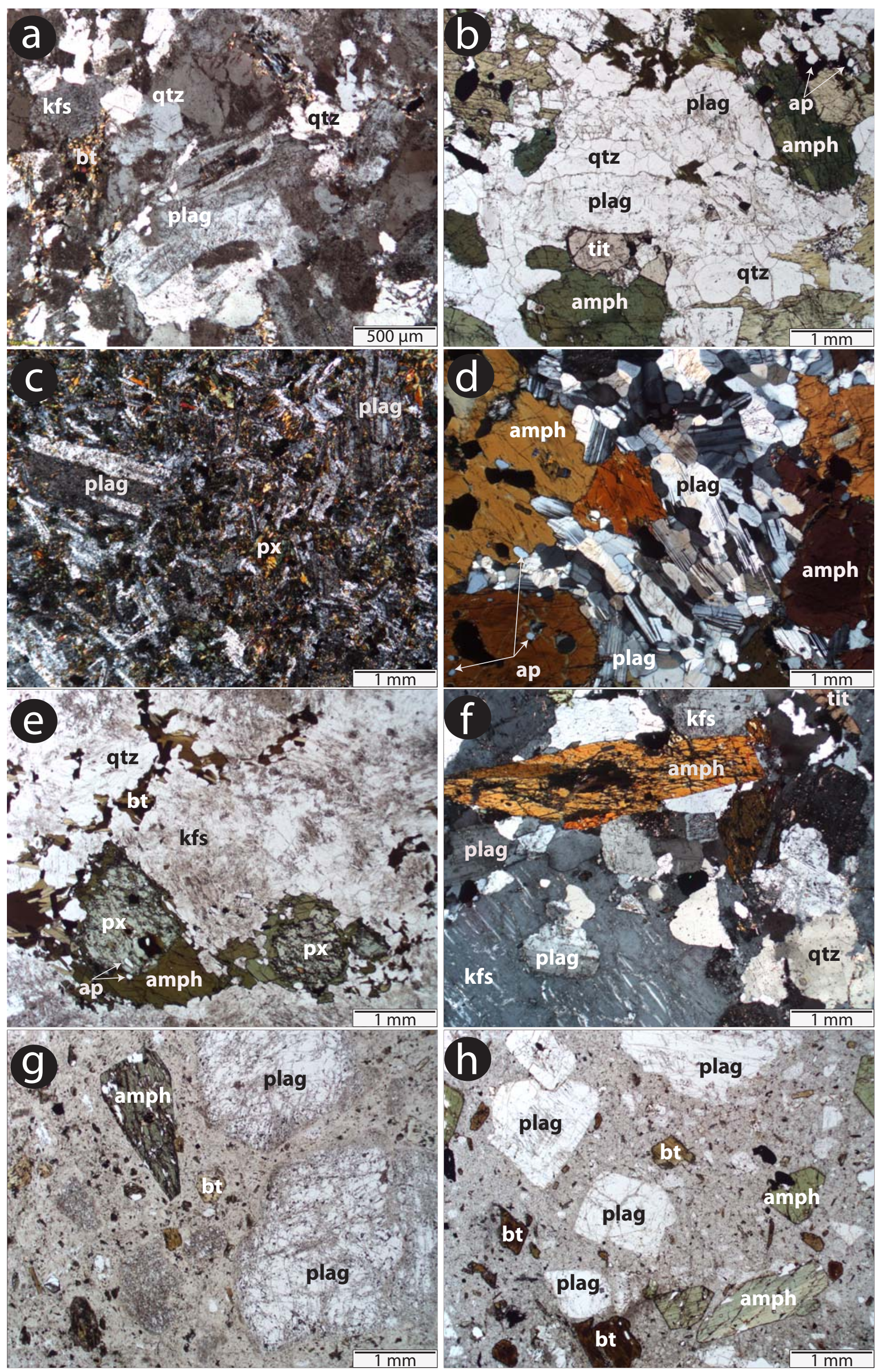

Fig. 7 

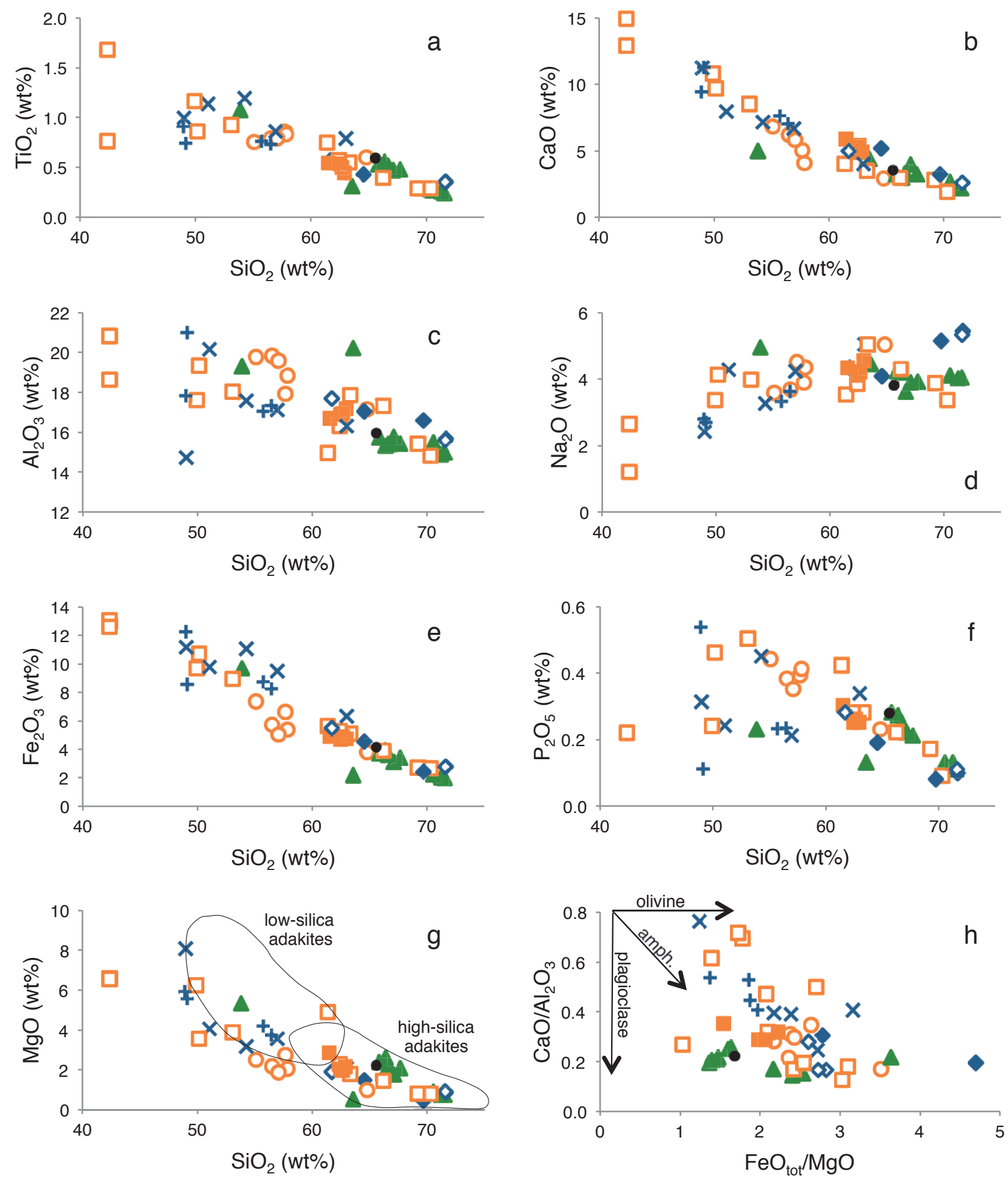

$\checkmark$ Eocene normal arc

* Eocene mafic, normal arc

+ Eocene Kapan block (Mederer et al., 2013)

Eocene adakitic-like

- Oligocene

O Oligocene shoshonitic

Oligocene adakitic

$\triangle$ Miocene adakitic

- Pliocene adakitic

Fig. 8 

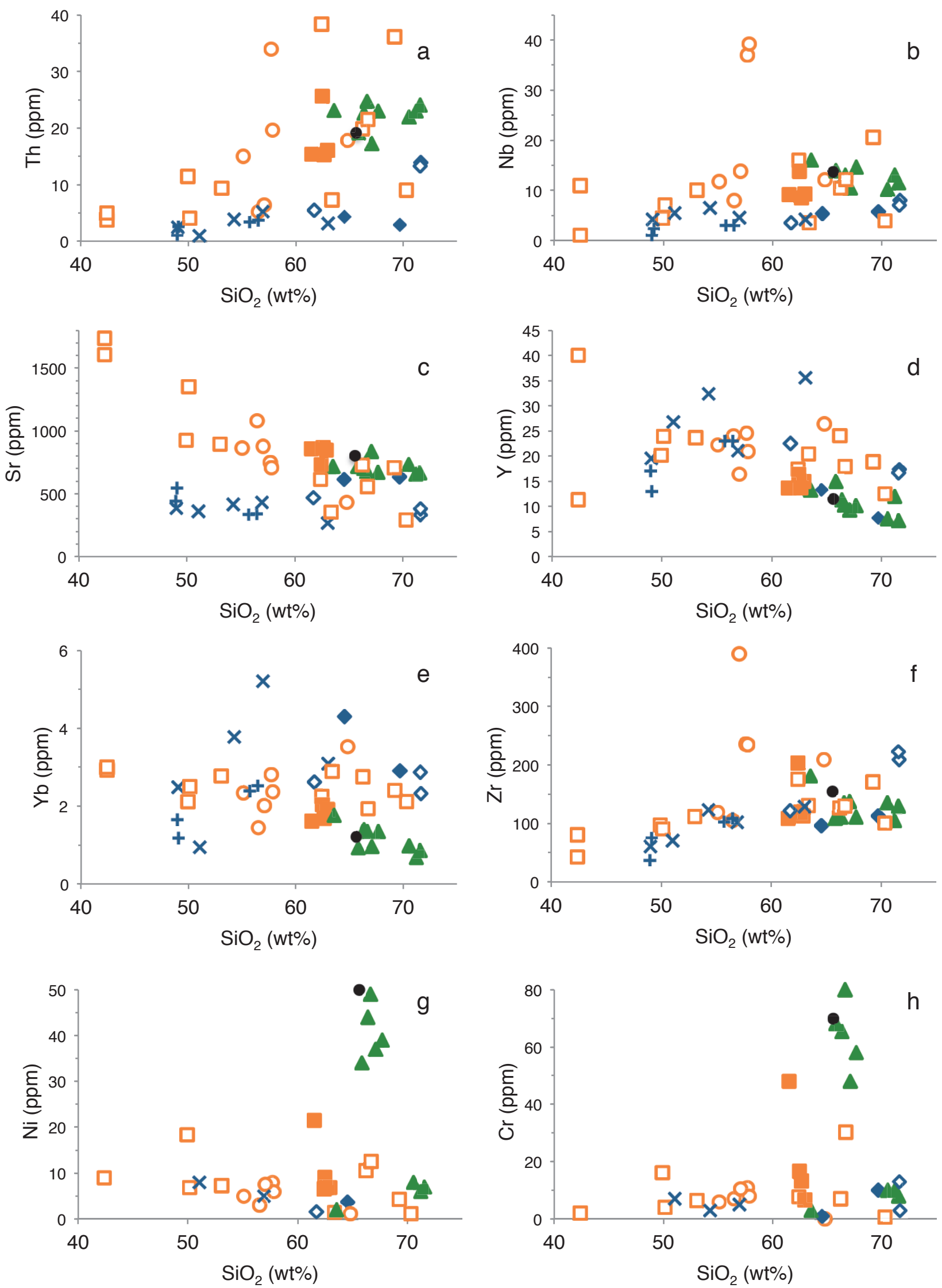

Fig. 9 

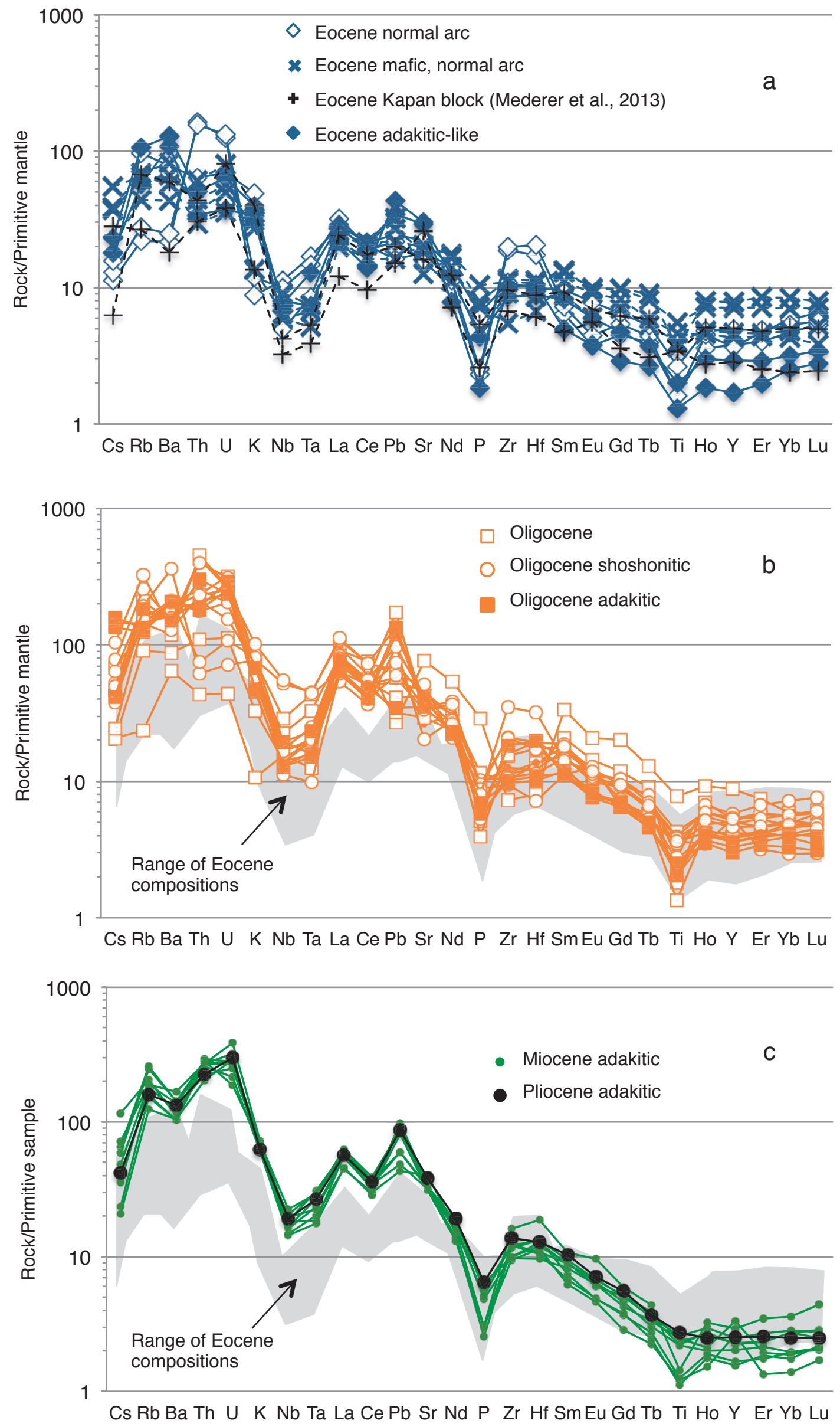

Fig. 10 

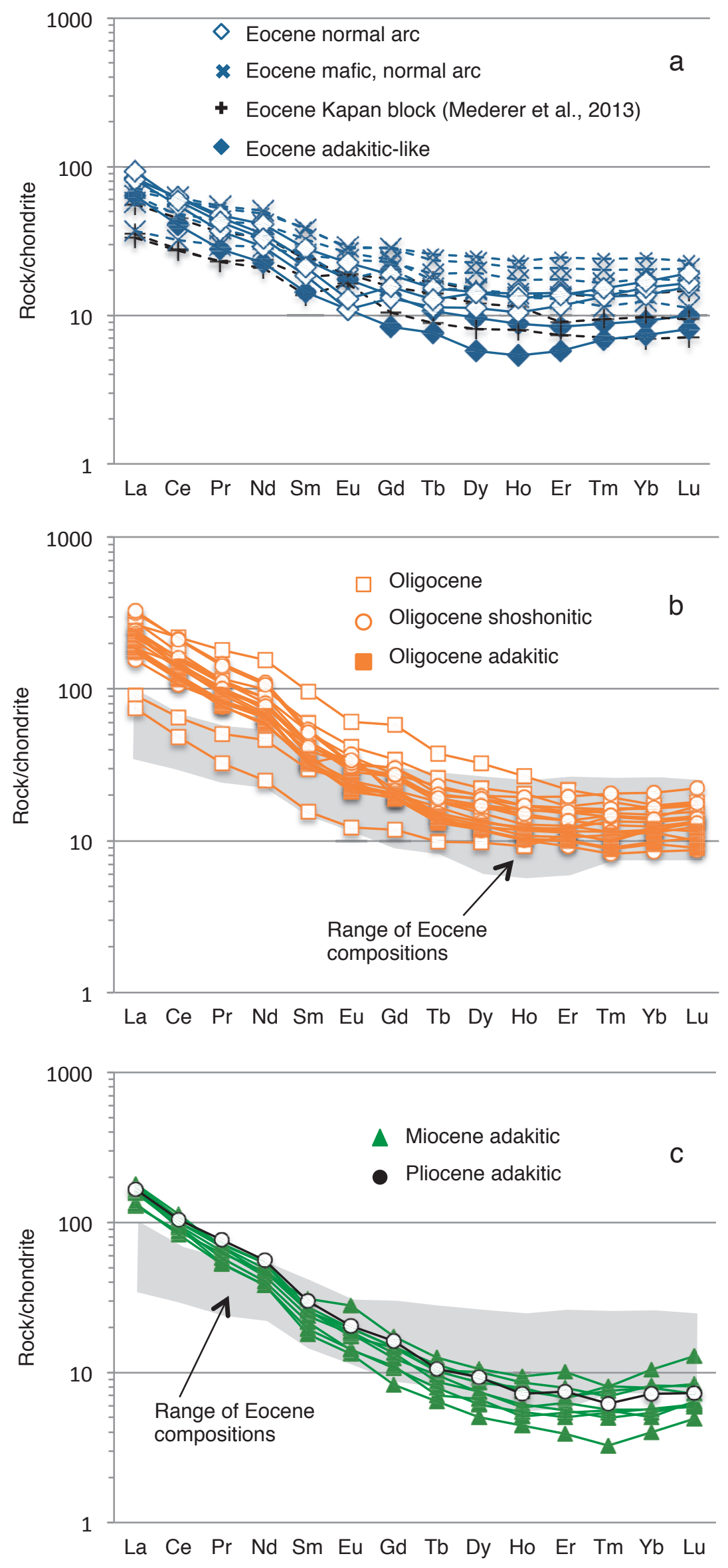

Fig. 11 

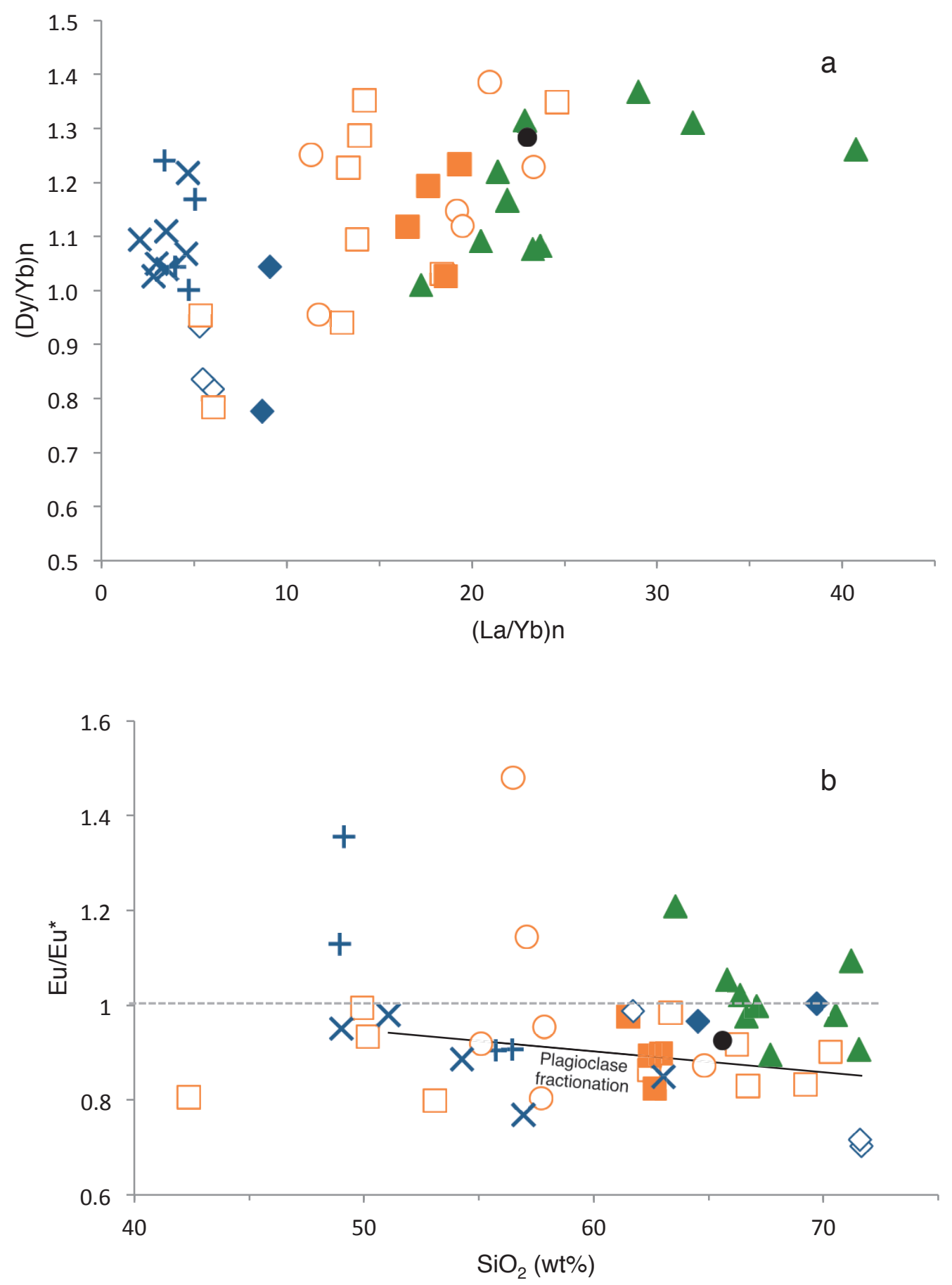

$\diamond$ Eocene normal arc

$\square$ Oligocene

* Eocene mafic, normal arc

- Oligocene shoshonitic

+ Eocene Kapan block (Mederer et al., 2013)

Oligocene adakitic

Eocene adakitic-like

$\triangle$ Miocene adakitic

- Pliocene adakitic

Fig. 12 

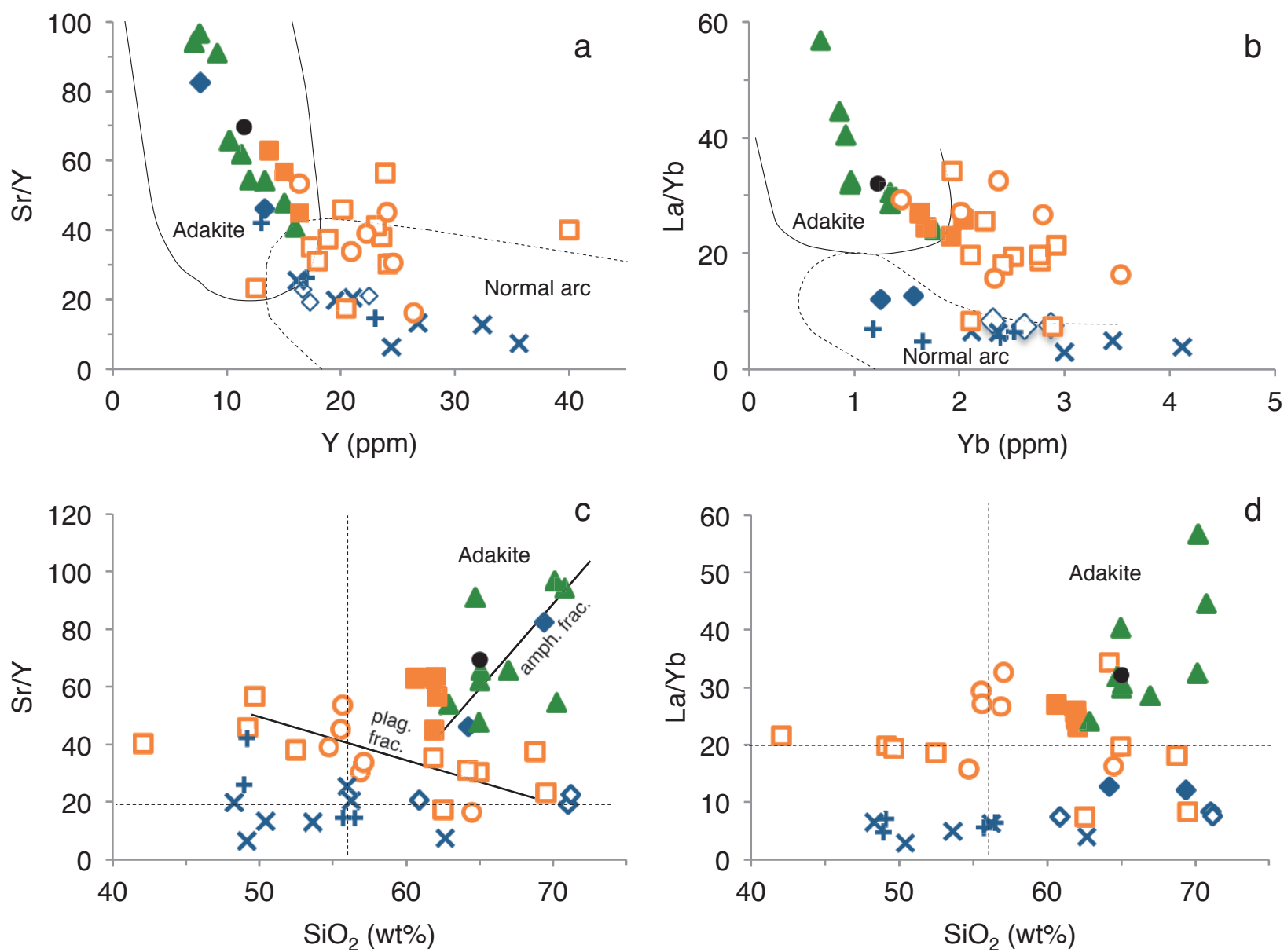

$\checkmark$ Eocene normal arc

$\square$ Oligocene

* Eocene mafic, normal arc

- Oligocene shoshonitic

+ Eocene Kapan block (Mederer et al., 2013)

Oligocene adakitic

Eocene adakitic-like

$\triangle$ Miocene adakitic

plag. frac.: plagioclase fractionation trend

- Pliocene adakitic

amph. frac.: amphibole fractionation trend

Fig. 13 

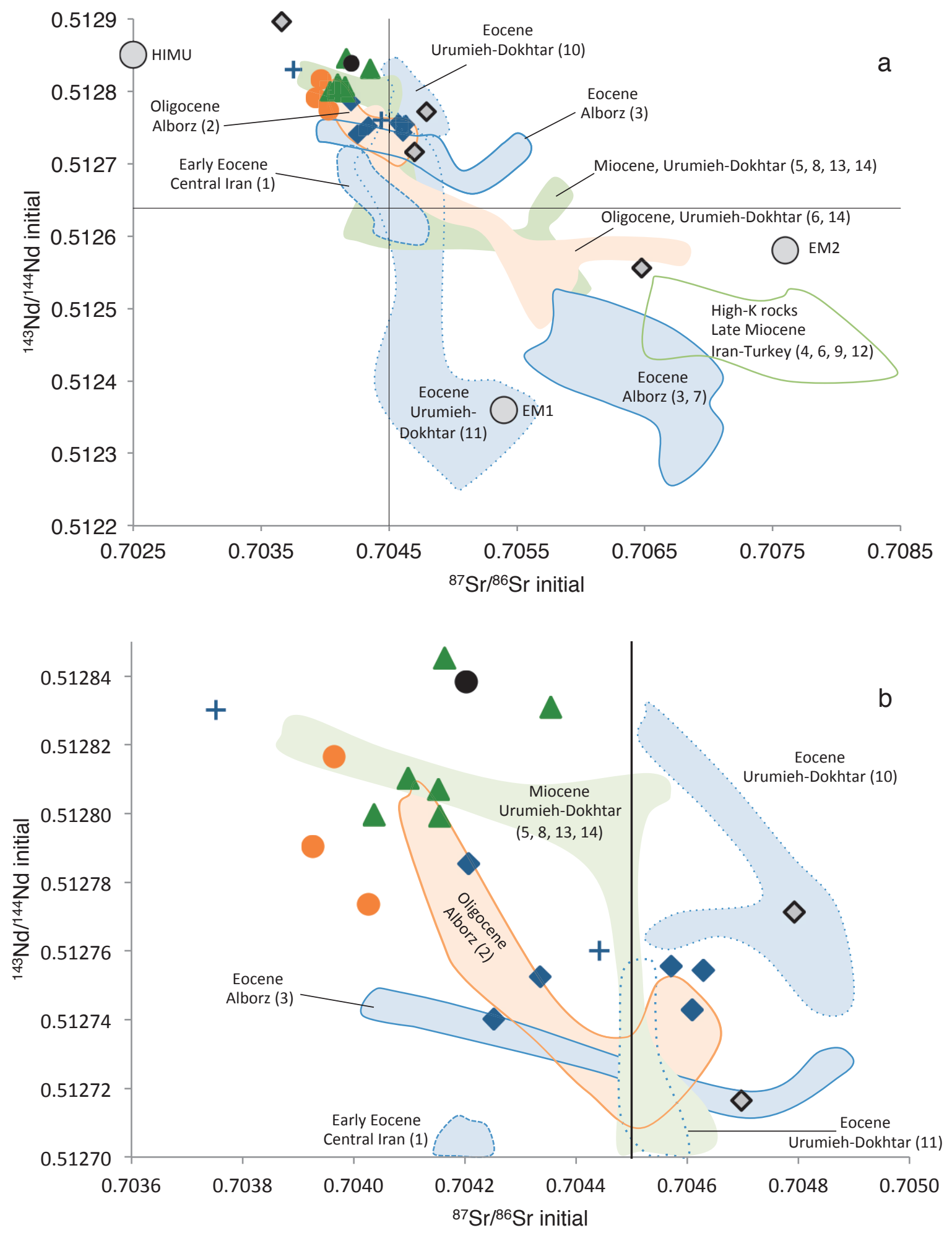

$\checkmark$ Eocene Urumieh-Dokhtar belt (Omrani et al., 2008) Oligocene Meghri-Ordubad pluton

+ Eocene Kapan block (Mederer et al., 2013)

$\triangle$ Miocene Meghri-Ordubad pluton

Eocene Meghri-Ordubad pluton

- Pliocene Meghri-Ordubad pluton

Fig. 14 

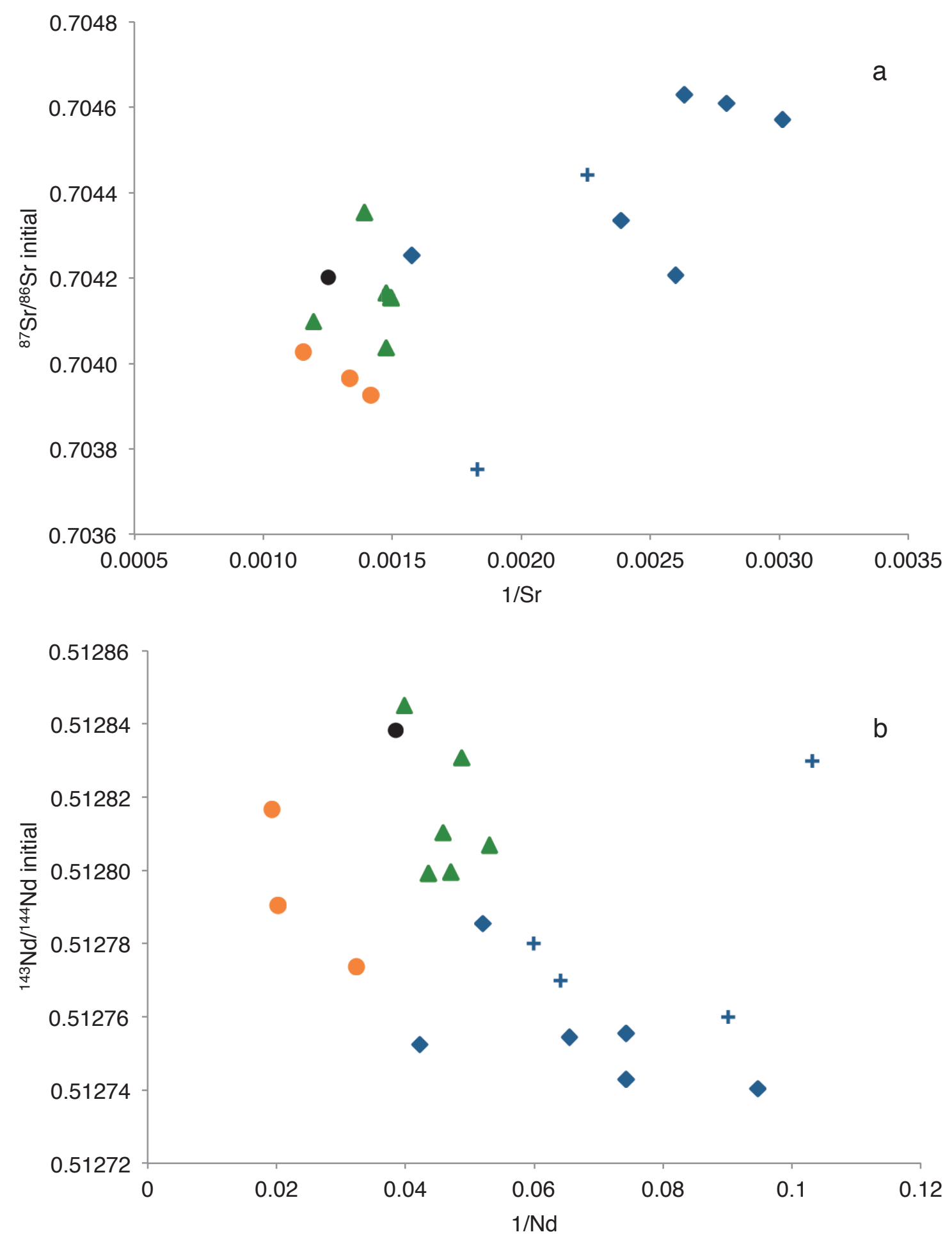

+ Eocene Kapan block (Mederer et al., 2013) Oligocene Meghri-Ordubad pluton

- Eocene Meghri-Ordubad pluton

\ Miocene Meghri-Ordubad pluton

- Pliocene Meghri-Ordubad pluton

Fig. 15 

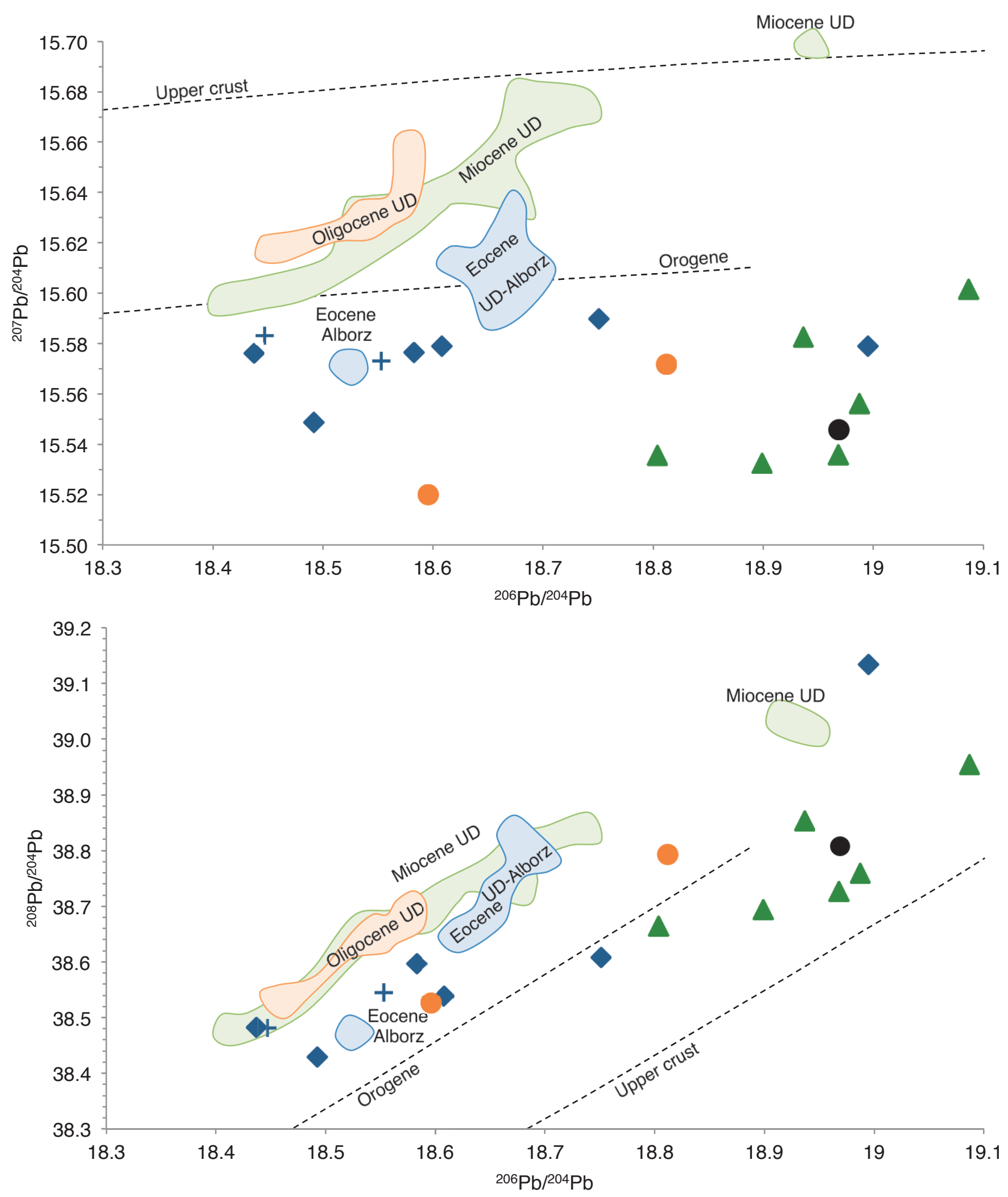

+ Eocene Kapan block (Mederer et al., 2013) Oligocene Meghri-Ordubad pluton

- Eocene Meghri-Ordubad pluton

\ Miocene Meghri-Ordubad pluton

- Pliocene Meghri-Ordubad pluton

Fig. 16 


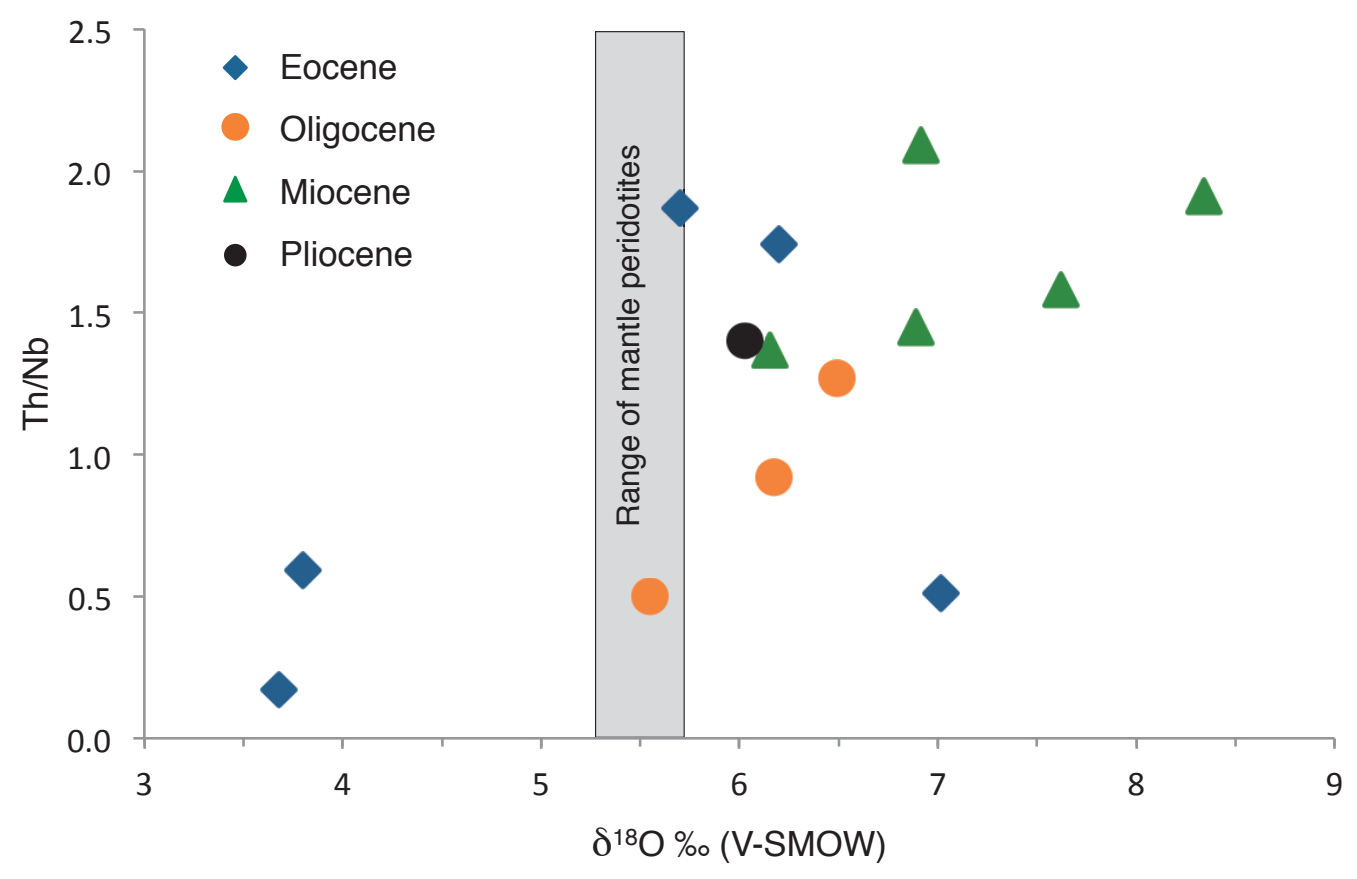

Fig. 17 

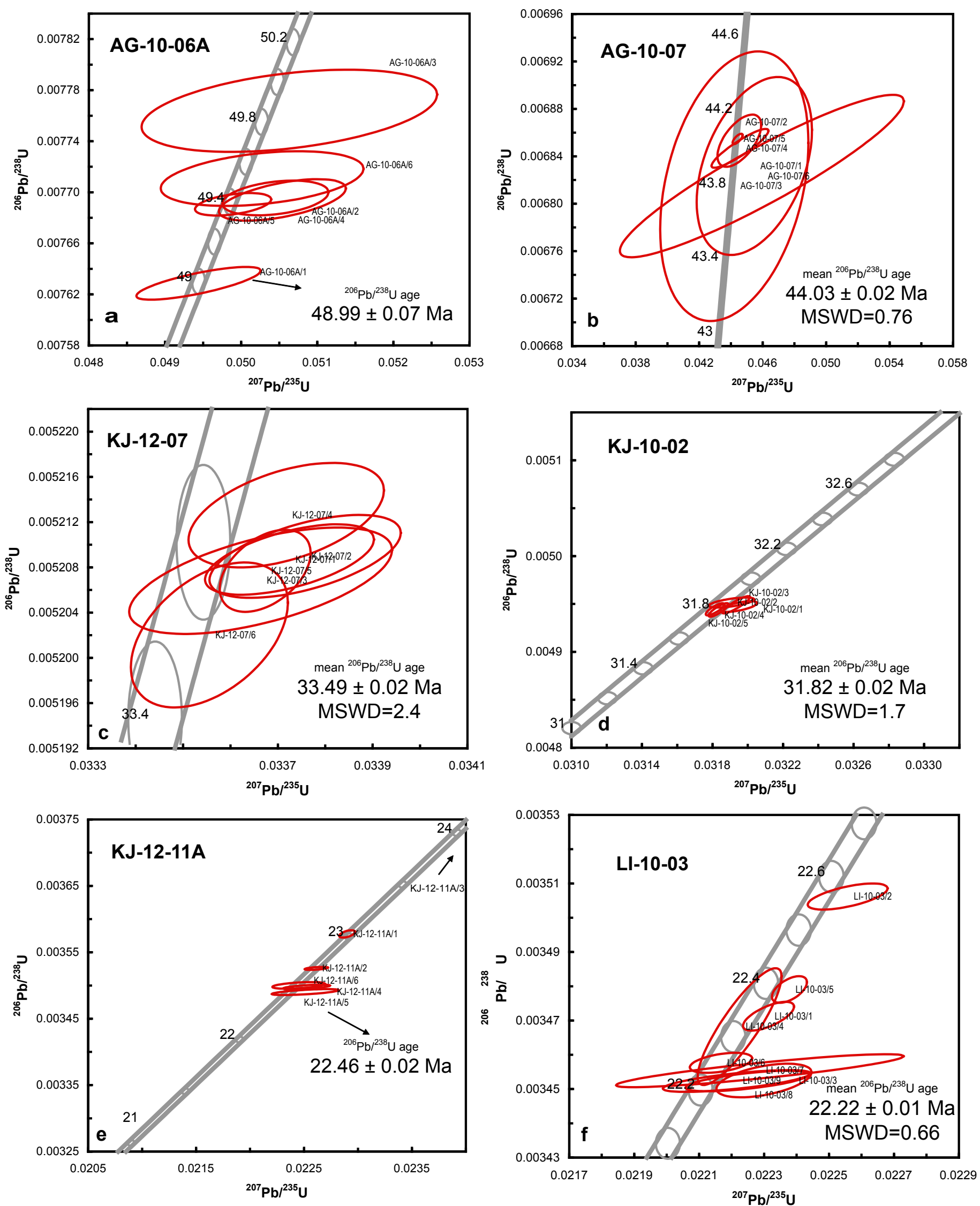

Fig. 18 

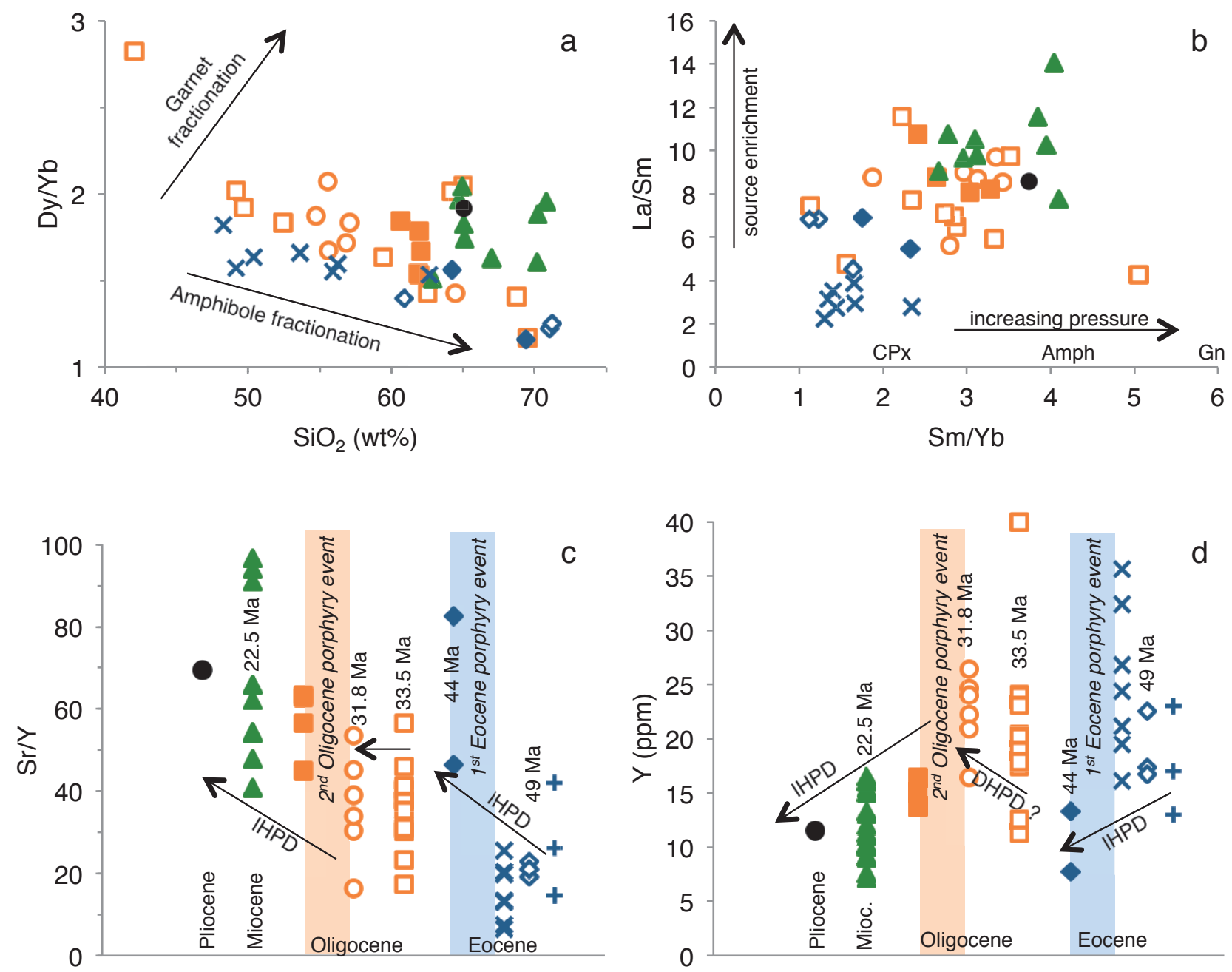

$\diamond$ Eocene normal arc

$\square$ Oligocene

* Eocene mafic, normal arc

- Oligocene shoshonitic

+ Eocene Kapan block (Mederer et al., 2013)

Oligocene adakitic

Eocene adakitic-like

$\triangle$ Miocene adakitic

IHPD: increasing high pressure differenciation

- Pliocene adakitic

DHPD: increasing high pressure differenciation

Fig. 19 

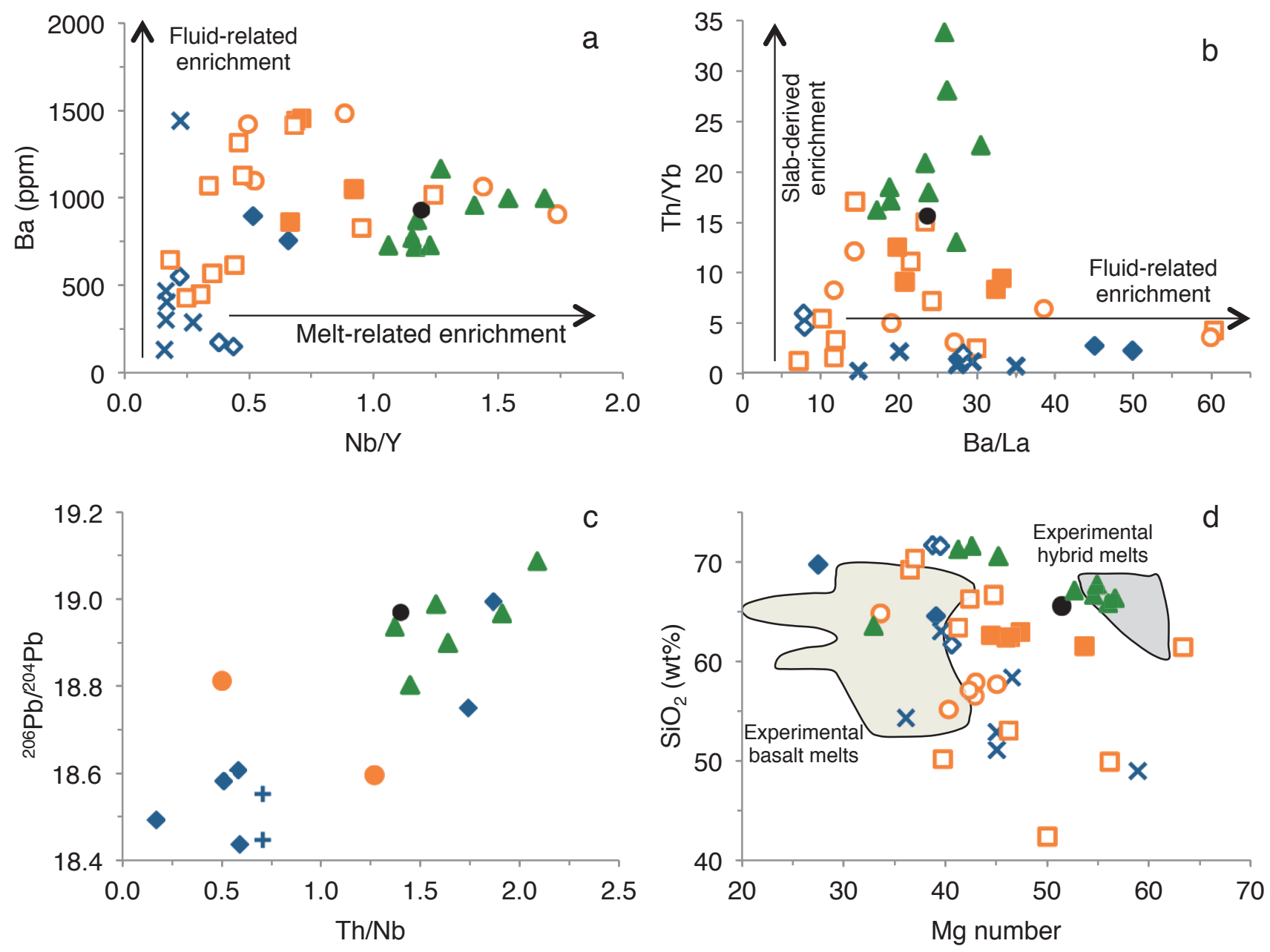

Figure c:

+ Eocene Kapan block (Mederer et al., 2013)

Figures $\mathrm{a}, \mathrm{b}$ and $\mathrm{d}$ :

$\diamond$ Eocene normal arc

- Eocene Meghri-Ordubad pluton

* Eocene mafic, normal arc

- Oligocene Meghri-Ordubad pluton

- Eocene adakitic-like

- Miocene Meghri-Ordubad pluton

$\square$ Oligocene

- Pliocene Meghri-Ordubad pluton

O Oligocene shoshonitic

Oligocene adakitic

$\Delta$ Miocene adakitic

- Pliocene adakitic

Fig. 20 


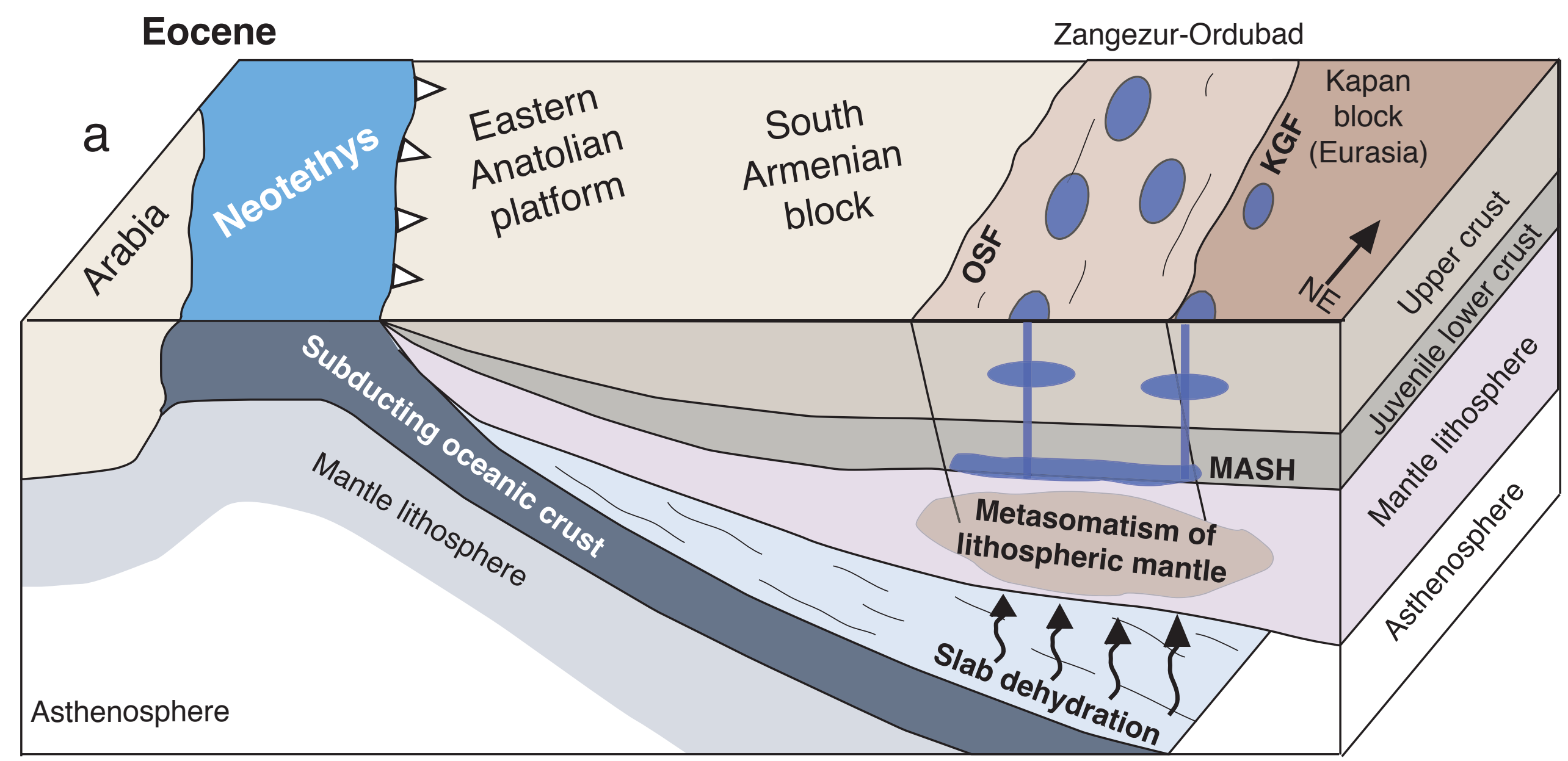

OSF: Ordubad-Salvard fault KGF: Khustup-Giratagh fault

\section{Early Oligocene}

Zangezur-Ordubad

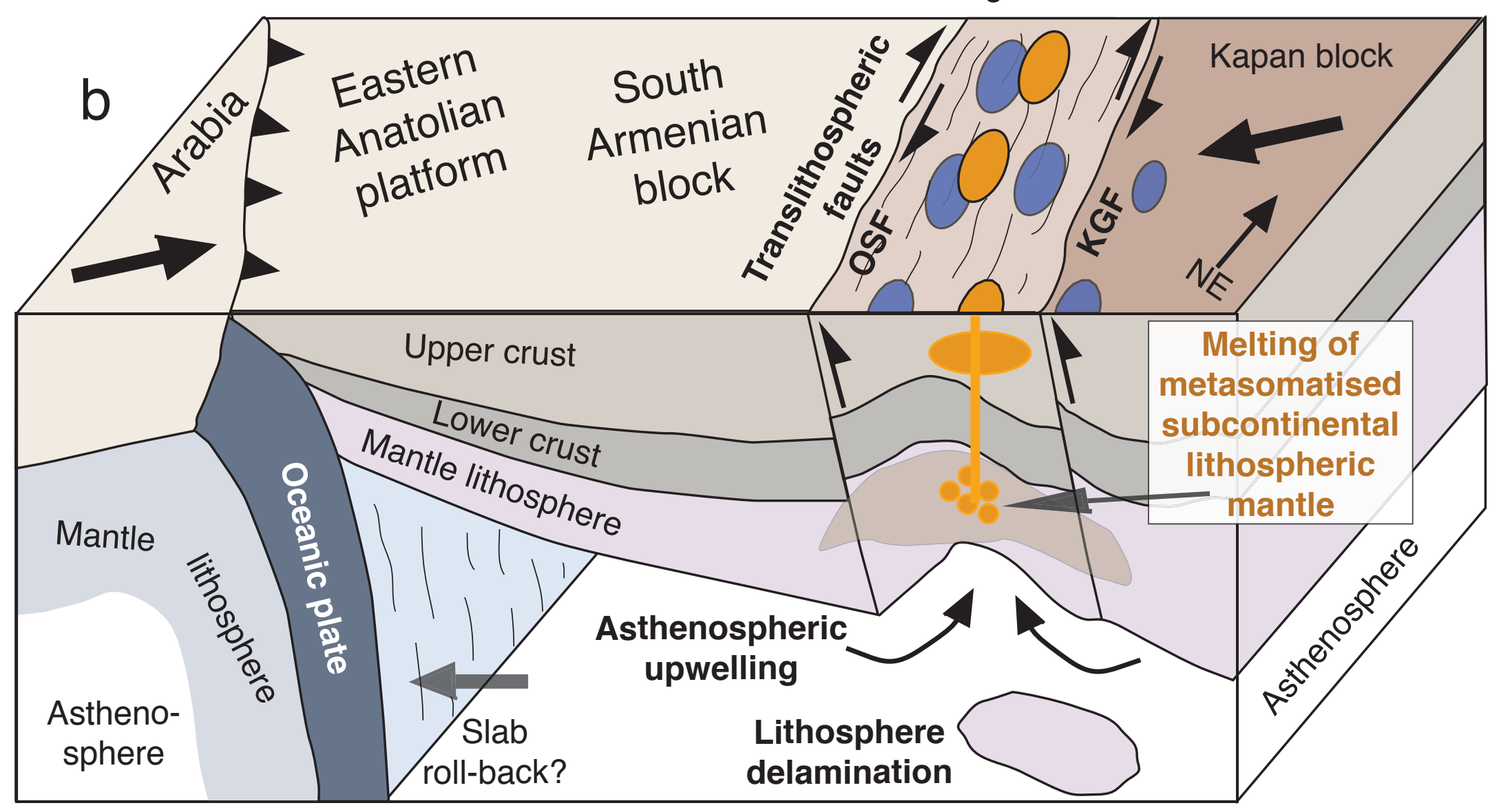

\section{Late Oligocene-Miocene}

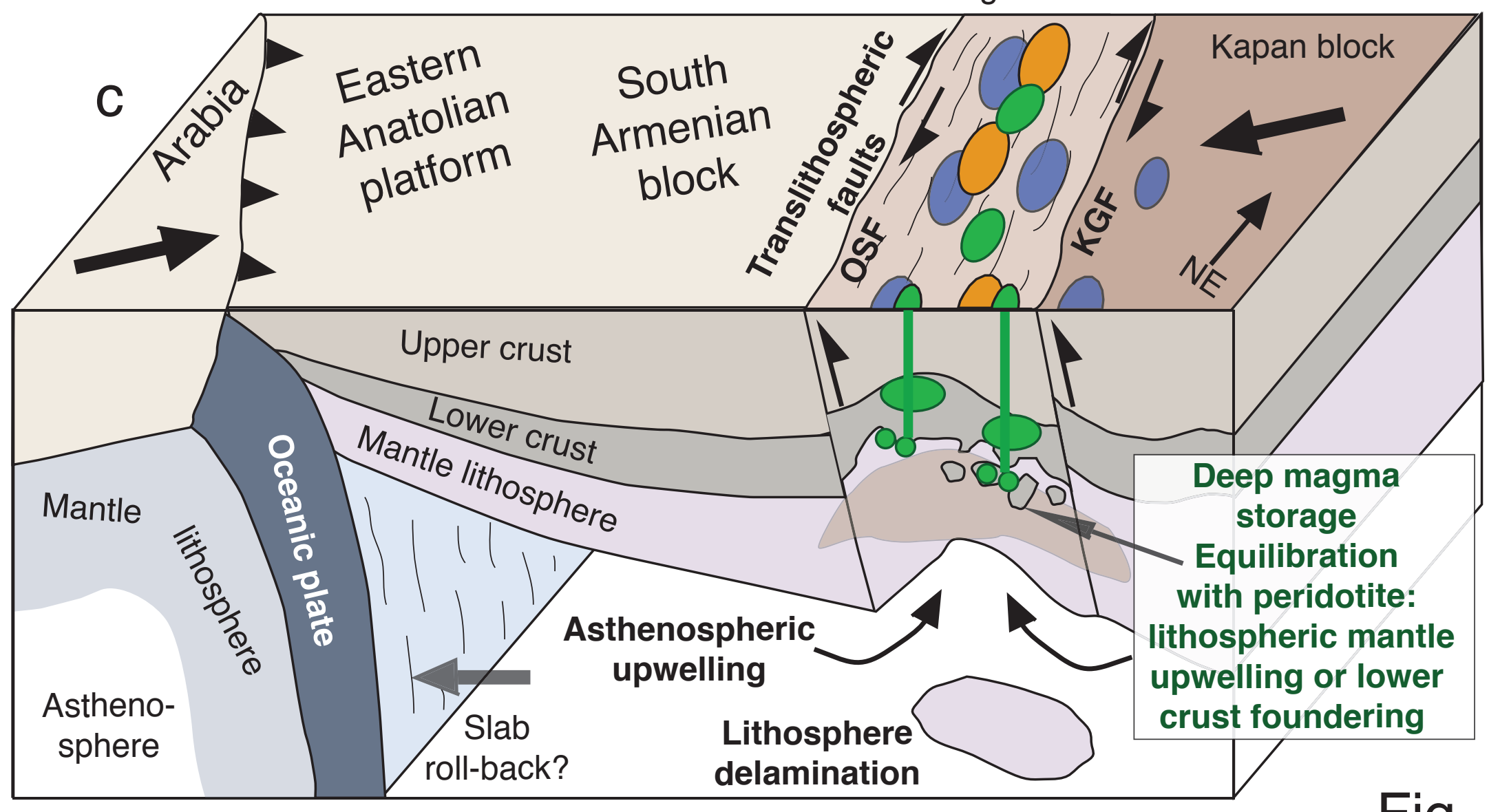

Fig. 21 

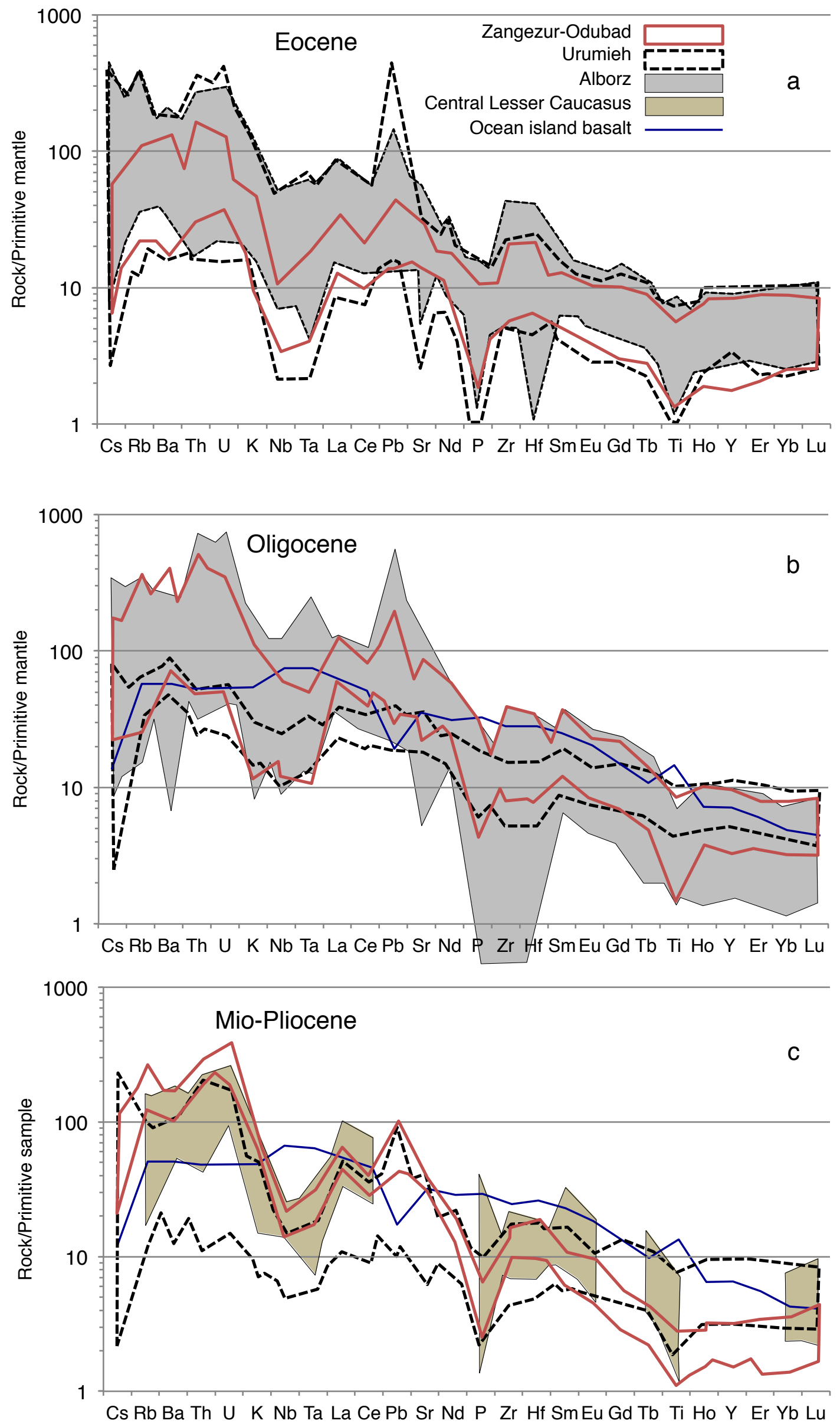

Fig. 22 

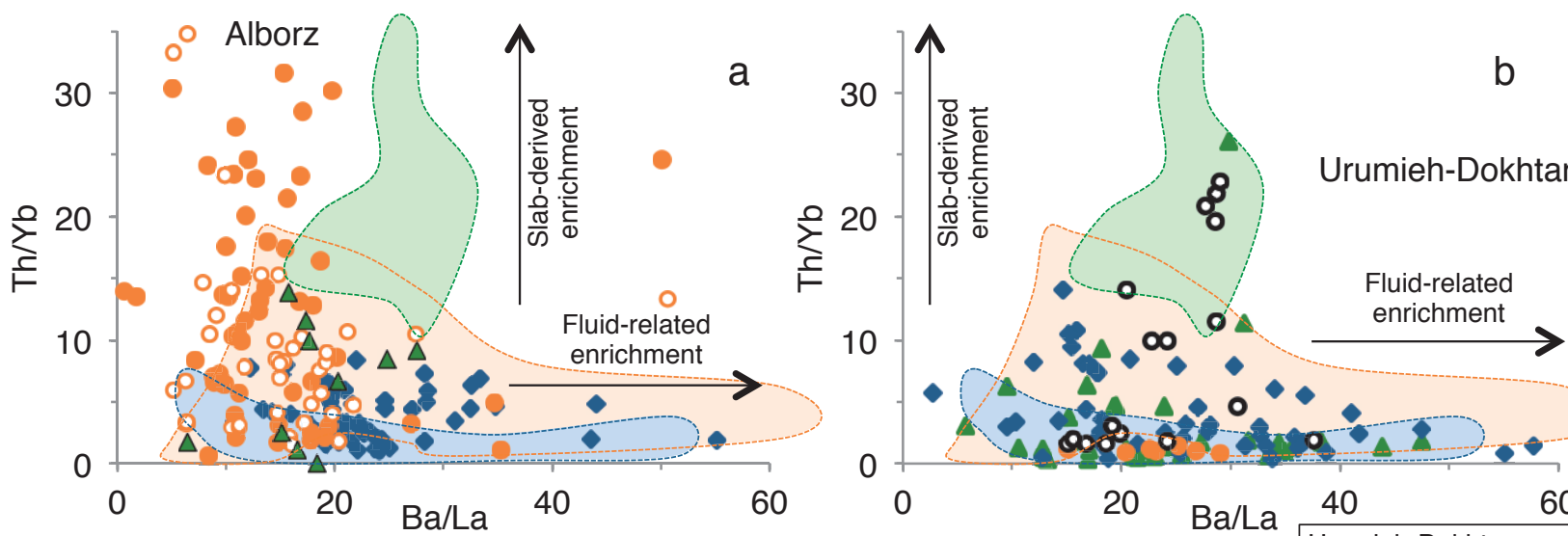

b
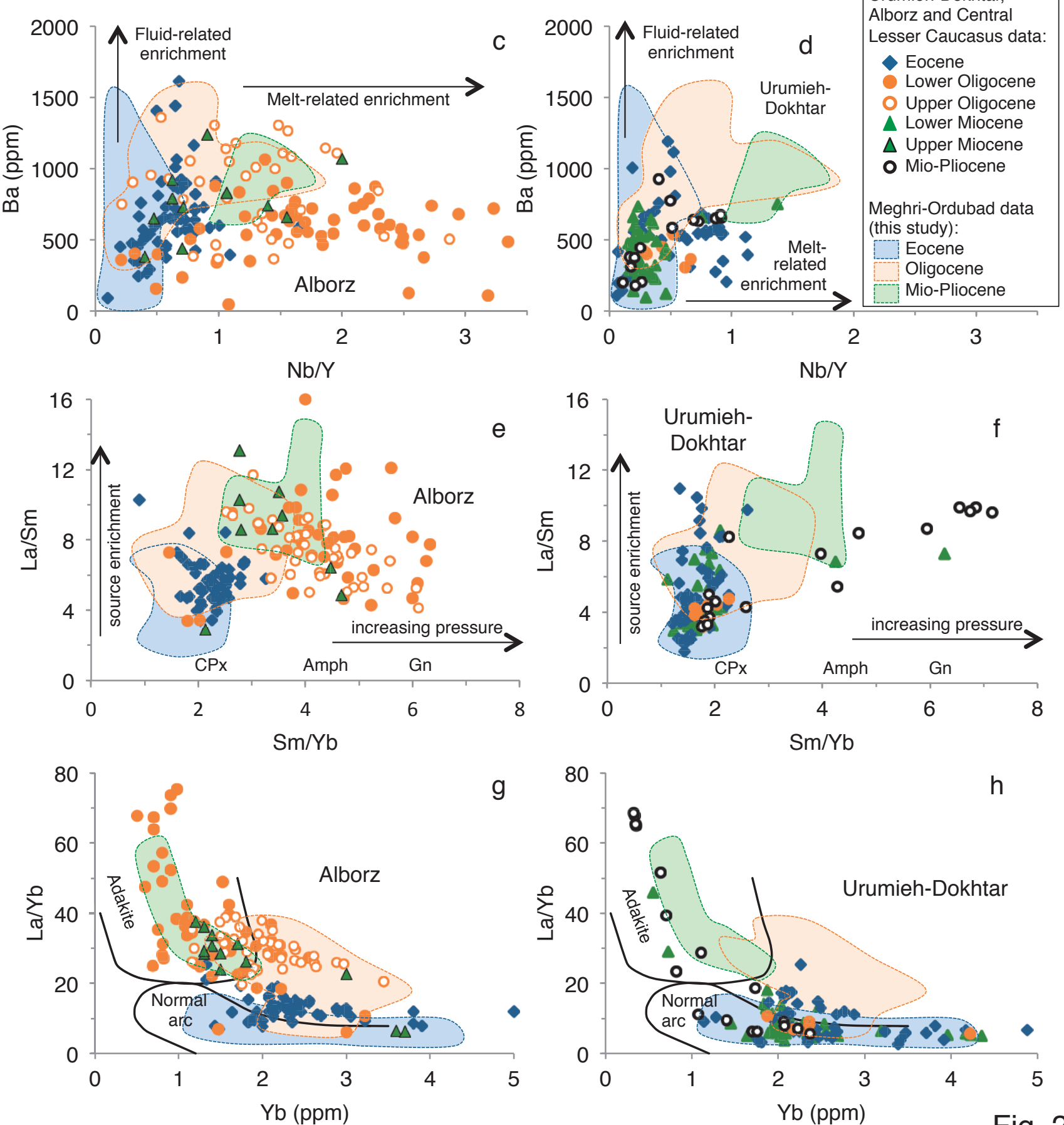

Fig. 23 
Table 1 - Main ore deposits and prospects of the Zangezur-Ordubad region, southern Armenia and Nakhitchevan

\begin{tabular}{|c|c|c|c|c|c|c|c|c|c|}
\hline Deposit & $\begin{array}{c}\text { Deposit } \\
\text { type }\end{array}$ & Reserves-ore grade & Status & Age & Host rock geology & Main mineralogy & Alteration & Ore body geometry & References \\
\hline Dastakert & $\begin{array}{l}\text { Porphyry- } \\
\text { Cu-Mo }\end{array}$ & $\begin{array}{c}9.6 \mathrm{Mt} @ 0.95 \% \mathrm{Cu}- \\
0.043 \% \mathrm{Mo}\end{array}$ & $\begin{array}{c}\text { In } \\
\text { development }\end{array}$ & $\begin{array}{l}40.22 \pm 0.16 \mathrm{Ma} \\
\text { to } 39.97 \pm 0.16 \\
\text { Ma (Molybdenite } \\
\text { Re-Os age) }\end{array}$ & $\begin{array}{l}\text { Eocene granodiorite } \\
\text { and andesite-basalte }\end{array}$ & $\begin{array}{c}\text { Molybdenite, chalcopyrite, pyrite, bornite, } \\
\text { chalcocite, covellite, emplectite, enargite, luzonite, } \\
\text { magnetite, gold, pyrrhotite, sphalerite, } \\
\text { tetrahedrite / tennantite, alabandite. Gangue: } \\
\text { quartz, carbonates, K-feldspar. }\end{array}$ & $\begin{array}{l}\text { Silicification, sericite, } \\
\text { argillic alteration } \\
\text { (kaolinite), } \\
\text { carbonates }\end{array}$ & $\begin{array}{l}\text { NW-oriented fracture } \\
\text { zone. Stockwork and } \\
\text { breccia (ore minerals } \\
\text { in matrix of breccia) }\end{array}$ & $\begin{array}{l}\text { Karamyan (1962, 1978), } \\
\text { Pijyan (1975). Re-Os ages } \\
\text { from Moritz et al. (2013) }\end{array}$ \\
\hline Hankasar & $\begin{array}{l}\text { Porphyry- } \\
\text { Cu-Mo }\end{array}$ & $\begin{array}{c}10.4 \mathrm{Mt} @ 0.45 \% \mathrm{Cu}- \\
0.038 \% \mathrm{Mo}\end{array}$ & $\begin{array}{c}\text { In } \\
\text { development }\end{array}$ & $\begin{array}{l}43.14 \pm 0.17 \mathrm{Ma} \\
\text { (Molybdenite Re- } \\
\text { Os age) }\end{array}$ & $\begin{array}{l}\text { Upper Eocene } \\
\text { granodiorite and } \\
\text { quartz-diorite }\end{array}$ & $\begin{array}{l}\text { Molybdenite, chalcopyrite, pyrite, galena, } \\
\text { sphalerite. Gangue: quartz, sericite, chlorite, } \\
\text { carbonates, K-feldspar, biotite. }\end{array}$ & $\begin{array}{l}\text { Silicification, sericite, } \\
\text { carbonates }\end{array}$ & Veins & $\begin{array}{l}\text { Karamyan (1978). Re-Os } \\
\text { age from Moritz et al. } \\
\text { (2013) }\end{array}$ \\
\hline Paragachay & $\begin{array}{l}\text { Porphyry- } \\
\text { Cu-Mo }\end{array}$ & $\begin{array}{l}\text { Past production: } 460 \text { tons } \\
\text { of Mo. Ore grades: } 0.01- \\
2.50 \% \mathrm{Mo}-0.1-21.5 \% \mathrm{Cu} \\
-1 \mathrm{~g} / \mathrm{t} \mathrm{Au}\end{array}$ & $\begin{array}{l}\text { Closed - } \\
\text { Prospect }\end{array}$ & $\begin{array}{l}26.78 \pm 0.11 \mathrm{Ma} \\
\text { (Molybdenite Re- } \\
\text { Os age) }\end{array}$ & $\begin{array}{l}\text { Quartz-diorite, } \\
\text { quartz syenodiorite }\end{array}$ & Chalcopyrite, pyrite, molybdenite, magnetite & $\begin{array}{l}\text { Silicification, sericite, } \\
\text { K-feldspar, argillic } \\
\text { alteration (kaolinite) }\end{array}$ & Vein, stockwork & $\begin{array}{l}\text { Babazadeh et al. (1990). } \\
\text { Re-Os age from Moritz et } \\
\text { al. (2013) }\end{array}$ \\
\hline Qapujuk & $\begin{array}{l}\text { Porphyry- } \\
\text { Cu-Mo }\end{array}$ & $\begin{array}{c}0.95 \mathrm{Mt} @ 1.14 \% \mathrm{Cu}- \\
0.17 \% \mathrm{Mo}-0.3 \mathrm{~g} / \mathrm{t} \mathrm{Au}- \\
4.0 \mathrm{~g} / \mathrm{t} \mathrm{Ag}\end{array}$ & Prospect & Eocene-Oligocene & $\begin{array}{l}\text { Gabbrodiorite, } \\
\text { diorite, quartz } \\
\text { syenodiorite }\end{array}$ & Molybdenite, chalcopyrite & $\begin{array}{l}\text { Silicification, sericite, } \\
\text { K-feldspar, argillic } \\
\text { alteration (kaolinite) }\end{array}$ & Stockwork & Babazadeh et al. (1990) \\
\hline Kadjaran & $\begin{array}{l}\text { Porphyry- } \\
\text { Cu-Mo, and } \\
\text { younger } \\
\text { epithermal } \\
\text { overprint }\end{array}$ & $\begin{array}{c}181 \mathrm{Mt} @ 0.65 \% \mathrm{Cu}- \\
0.057 \% \mathrm{Mo}-0.65 \mathrm{~g} / \mathrm{t} \mathrm{Au} \\
\text { (Armenian source: } 2244 \mathrm{Mt} \\
@ 0.18 \% \mathrm{Cu}-0.021 \% \mathrm{Mo}- \\
0.02 \mathrm{~g} / \mathrm{t} \mathrm{Au} \text { - Proven and } \\
\text { probable reserves, and } \\
\text { indicated resources) }\end{array}$ & - In production & $\begin{array}{l}27.2 \pm 0.1 \text { Ma to } \\
26.43 \pm 0.11 \mathrm{Ma} \\
\text { (Molybdenite Re- } \\
\text { Os age) }\end{array}$ & $\begin{array}{l}\text { Oligocene monzonite, } \\
\text { quartz-monzonite, } \\
\text { monzodiorite }\end{array}$ & $\begin{array}{l}\text { Pyrite, molybdenite, chalcopyrite, magnetite, } \\
\text { sphalerite, galena, subsidiary covellite, enargite, } \\
\text { luzonite, bornite, chalcocite, gold, tellurides, } \\
\text { tetrahedrite / tennantite. Gangue: quartz, } \\
\text { carbonates, sericite, biotite, adularia, gypsum, K- } \\
\text { feldspar. }\end{array}$ & $\begin{array}{l}\text { Sericite, quartz, } \\
\text { disseminated pyrite, } \\
\text { argillic alteration } \\
\text { (kaalinite), } \\
\text { carbonate }\end{array}$ & Stockwork, veins & $\begin{array}{c}\text { Mkrtchyan et al. (1969), } \\
\text { Movsesyan an Isaenko } \\
\text { (1974), Karamyan } \\
\text { (1978), Tayan (1984, } \\
\text { 1998). Re-Os ages from } \\
\text { Moritz et al. (2013). Ore } \\
\text { grades and tonnage from } \\
\text { Singer et al. (2002) }\end{array}$ \\
\hline Atkis & $\begin{array}{l}\text { Epithermal, } \\
\text { polymetallic }\end{array}$ & $\begin{array}{l}1.71 \mathrm{~g} / \mathrm{t} \mathrm{Au}-29.4 \mathrm{~g} / \mathrm{t} \mathrm{Ag}- \\
0.79 \% \text { Cu. No reported } \\
\text { tonnage. }\end{array}$ & Prospect & $\begin{array}{l}24 \pm 1 \mathrm{Ma}(\mathrm{K}-\mathrm{Ar} \\
\text { age of sericite } \\
\text { from altered host } \\
\text { rock) }\end{array}$ & $\begin{array}{l}\text { Monzonite-hornfels } \\
\text { contact }\end{array}$ & $\begin{array}{l}\text { Chalcopyrite, pyrite, sphalerite, galena, } \\
\text { molybdenite. Gangue: quartz, calcite }\end{array}$ & $\begin{array}{l}\text { Silicification, sericite, } \\
\text { pyrite, kaolinite, } \\
\text { chlorite, carbonate }\end{array}$ & Veins & $\begin{array}{l}\text { Mkrtchyan et al. (1969). } \\
\text { Age from Bagdasaryan et } \\
\text { al. (1969) }\end{array}$ \\
\hline Misdag & $\begin{array}{l}\text { Porphyry- } \\
\text { Cu-Mo }\end{array}$ & $\begin{array}{l}350 \mathrm{Mt} @ 0.43 \% \mathrm{Cu} \\
\text { (Inferred resources) }\end{array}$ & Prospect & Eocene-Oligocene & $\begin{array}{l}\text { Granodiorite, quartz- } \\
\text { syenodiorite }\end{array}$ & $\begin{array}{c}\text { Chalcopyrite, pyrite, molybdenite, magnetite, } \\
\text { quartz }\end{array}$ & $\begin{array}{l}\text { Silicification, sericite, } \\
\text { K-feldspar, argillic } \\
\text { alteration (kaolinite) }\end{array}$ & Vein, stockwork & Babazadeh et al. (1990) \\
\hline Agyurt & Epithermal & $\begin{array}{c}1.13 \mathrm{Mt} @ 1.28 \% \mathrm{Cu}-6.39 \\
\mathrm{~g} / \mathrm{t} \mathrm{Au}-23.4 \mathrm{~g} / \mathrm{t} \mathrm{Ag} \\
\text { (Probable reserves to } \\
\text { inferred resources) }\end{array}$ & Prospect & Eocene-Oligocene & $\begin{array}{l}\text { Granodiorite, diorite, } \\
\text { quartz syenodiorite }\end{array}$ & $\begin{array}{l}\text { Native gold and silver, sulphosalts, pyrite, } \\
\text { chalcopyrite, molybdenite, galena, sphalerite, } \\
\text { magnetite, quartz }\end{array}$ & & $\begin{array}{l}\text { NS-oriented veins } \\
\text { dipping steeply to the } \\
\text { W }\end{array}$ & Babazadeh et al. (1990) \\
\hline Piyazbashi & Epithermal & $\begin{array}{l}1.7 \mathrm{Mt} @ 8.6 \mathrm{~g} / \mathrm{t} \mathrm{Au}-3.4 \\
\mathrm{~g} / \mathrm{t} \mathrm{Ag} \text { (Proven and } \\
\text { probable reserves, and } \\
\text { inferred to indicated } \\
\text { resources) }\end{array}$ & Prospect & Eocene-Oligocene & $\begin{array}{l}\text { Andesitic tuff and } \\
\text { flow }\end{array}$ & Native gold, various sulphides, quartz & $\begin{array}{l}\text { Silicification, argillic } \\
\text { alteration (kaolinite) }\end{array}$ & Veins & $\begin{array}{l}\text { Ramazanov and Kerimli } \\
\text { (2012) }\end{array}$ \\
\hline
\end{tabular}


Table 1 - Continued

\begin{tabular}{|c|c|c|c|c|c|c|c|c|c|}
\hline Deposit & $\begin{array}{l}\text { Deposit } \\
\text { type }\end{array}$ & Reserves-ore grade & Status & Age & Host rock geology & Main mineralogy & Alteration & Ore body geometry & References \\
\hline Lichk & $\begin{array}{l}\text { Porphyry- } \\
\text { Cu-Mo }\end{array}$ & $\begin{array}{l}34 \mathrm{Mt} @ 0.63 \% \mathrm{Cu}- \\
0.033 \% \mathrm{Mo}-0.05 \mathrm{~g} / \mathrm{t} \mathrm{Au}- \\
0.11 \mathrm{~g} / \mathrm{t} \mathrm{Ag} \text { (Proven and } \\
\text { probable reserves) }\end{array}$ & Prospect & $\begin{array}{l}\text { Oligocene- } \\
\text { Miocene? }\end{array}$ & $\begin{array}{l}\text { Early Miocene } \\
\text { porphyritic } \\
\text { granodiorite }\end{array}$ & $\begin{array}{c}\text { Chalcopyrite, bornite, pyrite, molybdenite, } \\
\text { hematite, magnetite. Gangue: quartz, sericite, } \\
\text { carbonates }\end{array}$ & $\begin{array}{l}\text { Silicification, sericite, } \\
\text { argillic alteration } \\
\text { (kaolinite), } \\
\text { carbonates }\end{array}$ & Stockwork & $\begin{array}{l}\text { Pijyan (1975), Karamyan } \\
\text { (1978), Tayan (1998) and } \\
\text { Hovakimyan (2008) }\end{array}$ \\
\hline Diakhchay & $\begin{array}{l}\text { Porphyry- } \\
\text { Cu-Mo }\end{array}$ & $\begin{array}{l}14.4 \mathrm{Mt} @ 0.44 \% \mathrm{Cu}- \\
0.015 \% \mathrm{Mo}\end{array}$ & Prospect & Eocene-Oligocene & Quartz-diorite & $\begin{array}{l}\text { Chalcopyrite, pyrite, molybdenite, magnetite, } \\
\text { quartz }\end{array}$ & $\begin{array}{l}\text { Silicification, sericite, } \\
\text { K-feldspar, argillic } \\
\text { alteration (kaolinite) }\end{array}$ & $\begin{array}{l}\text { Vein, stockwork, } \\
\text { along main Ordubad } \\
\text { fault }\end{array}$ & Babazadeh et al. (1990) \\
\hline $\begin{array}{c}\text { Tey- } \\
\text { Lichkvaz }\end{array}$ & $\begin{array}{l}\text { Epithermal, } \\
\text { polymetallic }\end{array}$ & $\begin{array}{l}\text { 3.5 Mt @ } 0.44 \% \mathrm{Cu}-5.93 \\
\mathrm{~g} / \mathrm{t} \mathrm{Au}-35.12 \mathrm{~g} / \mathrm{t} \mathrm{Ag} \\
\text { (Proven and probable } \\
\text { reserves). }\end{array}$ & Prospect & $\begin{array}{c}37.5 \pm 0.5 \mathrm{Ma} \text { and } \\
38.0 \pm 2.5 \mathrm{Ma}(\mathrm{K}- \\
\text { Ar age of sericite } \\
\text { from altered host } \\
\text { rock) }\end{array}$ & $\begin{array}{l}\text { Eocene granodiorite } \\
\text { and syenodiorite and } \\
\text { Middle Eocene basalt } \\
\text { and andesite }\end{array}$ & $\begin{array}{c}\text { Native gold, chalcopyrite, arsenopyrite, tellurides, } \\
\text { pyrite }\end{array}$ & $\begin{array}{l}\text { Silicification, sericite, } \\
\text { carbonates }\end{array}$ & Stockwork and vein & $\begin{array}{l}\text { Amiryan (1984) and } \\
\text { Hovakimyan (2010). Ages } \\
\text { from Bagdasaryan et al. } \\
\text { (1969) }\end{array}$ \\
\hline Terterasar & $\begin{array}{l}\text { Epithermal, } \\
\text { polymetallic }\end{array}$ & $\begin{array}{l}0.5 \mathrm{Mt} @ 11 \mathrm{~g} / \mathrm{t} \mathrm{Au}-74.8 \\
\mathrm{~g} / \mathrm{t} \mathrm{Ag}-0.45 \% \text { Cu (Proven } \\
\text { and probable reserves) }\end{array}$ & Prospect & Upper Eocene? & $\begin{array}{l}\text { Eocene granodiorite } \\
\text { and syenodiorite and } \\
\text { Middle Eocene basalt } \\
\text { and andesite }\end{array}$ & $\begin{array}{c}\text { Native gold, base metal sulphides, pyrite } \\
\text { chalcopyrite, arsenopyrite, tellurides. Gangue: } \\
\text { quartz, carbonates }\end{array}$ & $\begin{array}{l}\text { Sericite, carbonates, } \\
\text { argillic alteration } \\
\text { (kaolinite), } \\
\text { carbonates } \\
\text { tourmalinization, } \\
\text { silicification }\end{array}$ & Veins and veinlets & $\begin{array}{l}\text { Amiryan (1984), } \\
\text { Hovakimyan and Tayan } \\
\text { (2008) }\end{array}$ \\
\hline Aygedzor & $\begin{array}{l}\text { Porphyry- } \\
\text { Cu-Mo }\end{array}$ & $\begin{array}{l}51.6 \mathrm{Mt} @ 0.172 \% \mathrm{Cu}- \\
0.042 \% \mathrm{Mo}-0.05 \mathrm{~g} / \mathrm{t} \mathrm{Au}- \\
0.11 \mathrm{~g} / \mathrm{t} \mathrm{Ag} \text { (Proven and } \\
\text { probable reserves and } \\
\text { indicated resources) }\end{array}$ & Prospect & $\begin{array}{l}42.62 \pm 0.17 \mathrm{Ma} \\
\text { (Molybdenite Re- } \\
\text { Os age) }\end{array}$ & $\begin{array}{l}\text { Eocene granodiorite, } \\
\text { syenogranite }\end{array}$ & $\begin{array}{l}\text { Molybdenite, chalcopyrite, galena, sphalerite, } \\
\text { pyrite, enargite, quartz }\end{array}$ & $\begin{array}{l}\text { Silicification, sericite, } \\
\text { argillic alteration } \\
\text { (kaolinite), } \\
\text { carbonates }\end{array}$ & Stockwork and vein & $\begin{array}{l}\text { Pijyan (1975), Karamyan } \\
\text { (1978), Tayan (1998) and } \\
\text { Hovakimyan and Tayan } \\
\text { (2008). Re-Os age from } \\
\text { Moritz et al. (2013) }\end{array}$ \\
\hline Agarak & $\begin{array}{l}\text { Porphyry- } \\
\text { Cu-Mo }\end{array}$ & $\begin{array}{l}45 \mathrm{Mt} @ 0.5 \% \mathrm{Cu}- \\
0.029 \% \mathrm{Mo}-0.025 \mathrm{~g} / \mathrm{t} \mathrm{Au}- \\
1.19 \mathrm{~g} / \mathrm{t} \mathrm{Ag} \text { (Proven and } \\
\text { probable reserves) }\end{array}$ & In production & $\begin{array}{l}44.2 \pm 0.2 \mathrm{Ma} \\
\text { (Molybdenite Re- } \\
\text { Os age) }\end{array}$ & $\begin{array}{l}\text { Eocene porphyritic } \\
\text { leucocratic } \\
\text { granodiorite, } \\
\text { syenogranite }\end{array}$ & $\begin{array}{l}\text { Pyrite, molybdenite, chalcopyrite, bornite, } \\
\text { magnetite, sphalerite, galena, covellite, subsidiary } \\
\text { covellite, enargite. Gangue: quartz, sericite, } \\
\text { chlorite, carbonates, K-feldspar, biotite }\end{array}$ & $\begin{array}{l}\text { Sericite, quartz, } \\
\text { disseminated pyrite, } \\
\text { argillic alteration } \\
\text { (kaolinite), } \\
\text { carbonate, albite, } \\
\text { chlorite, biotite }\end{array}$ & Stockwork & $\begin{array}{c}\text { Pijyan (1975), Karamyan } \\
\text { (1978), Tayan (1998) and } \\
\text { Tayan et al. (2007). Re- } \\
\text { Os age from Moritz et al. } \\
\text { (2013) }\end{array}$ \\
\hline
\end{tabular}


Table 2 - Geochemical whole rock data for magmatic rocks from the composite Meghri-Ordubad and Bargushat plutons

\begin{tabular}{|c|c|c|c|c|c|c|c|c|c|c|c|}
\hline Sample & AG-10-03 & AG-10-04 & AG-10-05B & AG-10-06A & AG-10-07 & DA-10-04 & DA-12-03 & KJ-10-03 & KJ-10-10 & $N A K-14$ & NAK-15 \\
\hline Location & $\begin{array}{l}\text { Agarak, next } \\
\text { to open pit }\end{array}$ & $\begin{array}{l}\text { Agarak, next } \\
\text { to open pit }\end{array}$ & $\begin{array}{l}\text { Agarak, next } \\
\text { to open pit }\end{array}$ & $\begin{array}{c}\text { Agarak, next } \\
\text { to open pit }\end{array}$ & $\begin{array}{l}\text { Agarak, next } \\
\text { to open pit }\end{array}$ & Dastakert & Dastakert & Atkis & $\begin{array}{l}\text { Kadjaran, } \\
\text { Voghchi sec. }\end{array}$ & Nakhitchevan & Nakhitchevan \\
\hline Latitude (N) & 3853.844 & 3853.831 & 3853.759 & 3853.735 & 3853.862 & 3921.238 & 3921.647 & 3909.584 & 3909.797 & 3900.360 & 3901.245 \\
\hline Longitude (E) & 4611.684 & 4611.705 & 4611.756 & 4611.780 & 4613.274 & 4601.863 & 4601.656 & 4609.528 & 4612.471 & 4558.448 & 4557.959 \\
\hline Rock type & Granodiorite & Trachybasalt & $\begin{array}{l}\text { Bas. andesite } \\
\text { enclave }\end{array}$ & Granodiorite & Granite & Basalt & $\begin{array}{l}\text { Quartz } \\
\text { monzonite }\end{array}$ & $\begin{array}{c}\text { Basalt } \\
\text { (Kaputjugh) }\end{array}$ & $\begin{array}{l}\text { Bas. andesite } \\
\text { (Kaputjugh) }\end{array}$ & $\begin{array}{c}\text { Altered } \\
\text { andesite }\end{array}$ & $\begin{array}{c}\text { Altered } \\
\text { andesite }\end{array}$ \\
\hline Age (Ma) & Eocene & Eocene & Eocene & $48.99 \pm 0.07^{\star \star}$ & $44.03 \pm 0.02^{\star \star}$ & Eocene & Eocene & Eocene & Eocene & Eocene & Eocene \\
\hline $\mathrm{SiO} 2$ & 71.04 & 50.42 & 56.24 & 71.20 & 69.40 & 62.65 & 64.20 & 48.30 & 53.62 & 55.92 & 49.15 \\
\hline TiO2 & 0.35 & 1.12 & 0.85 & 0.35 & 0.28 & 0.79 & 0.43 & 0.98 & 1.18 & 0.62 & 0.99 \\
\hline $\mathrm{Al} 2 \mathrm{O} 3$ & 15.54 & 19.90 & 16.90 & 15.51 & 16.51 & 16.22 & 16.95 & 14.51 & 17.36 & 18.21 & 16.03 \\
\hline $\mathrm{Fe} 2 \mathrm{O} 3$ & 2.74 & 9.68 & 9.35 & 2.77 & 2.39 & 6.28 & 4.52 & 11.01 & 10.95 & 6.49 & 8.72 \\
\hline $\mathrm{MnO}$ & 0.01 & 0.09 & 0.14 & 0.01 & 0.09 & 0.11 & 0.14 & 0.20 & 0.21 & 0.09 & 0.43 \\
\hline $\mathrm{MgO}$ & 0.87 & 4.01 & 3.52 & 0.91 & 0.46 & 2.08 & 1.46 & 7.97 & 3.12 & 2.86 & 3.61 \\
\hline $\mathrm{CaO}$ & 2.57 & 7.85 & 6.59 & 2.58 & 3.22 & 3.98 & 5.17 & 11.08 & 7.08 & 7.21 & 5.85 \\
\hline $\mathrm{Na} 2 \mathrm{O}$ & 5.40 & 4.22 & 4.18 & 5.30 & 5.12 & 5.01 & 4.06 & 2.37 & 3.23 & 3.66 & 4.74 \\
\hline $\mathrm{K} 2 \mathrm{O}$ & 0.53 & 1.22 & 0.80 & 0.72 & 2.01 & 1.95 & 2.36 & 1.83 & 1.61 & 0.60 & 3.24 \\
\hline P2O5 & 0.10 & 0.24 & 0.21 & 0.11 & 0.08 & 0.34 & 0.19 & 0.31 & 0.45 & 0.19 & 0.26 \\
\hline LOI & 0.69 & 0.93 & 0.73 & 0.67 & 0.38 & 0.63 & 0.42 & 0.63 & 0.88 & 3.49 & 6.31 \\
\hline Total & 99.84 & 99.67 & 99.52 & 100.13 & 99.93 & 100.03 & 99.90 & 99.23 & 99.68 & 99.33 & 99.34 \\
\hline $\mathrm{Nb}$ & 8 & 5.5 & 4.6 & 7.1 & 5.7 & 4 & 5 & 4.2 & 6.5 & 4 & 6 \\
\hline $\mathrm{Zr}$ & 209 & 70 & 102 & 222 & 113 & 129 & 96 & 61 & 123 & 92 & 119 \\
\hline$Y$ & 17 & 27 & 21 & 17 & 7.7 & 36 & 13 & 20 & 32 & 16 & 24 \\
\hline $\mathrm{Sr}$ & 332 & 358 & 431 & 380 & 635 & 265 & 615 & 385 & 419 & 409 & 156 \\
\hline $\mathrm{Rb}$ & 14 & 57 & 28 & 17 & 37 & 44 & 67 & 41 & 40 & 11 & 54 \\
\hline $\mathrm{Pb}$ & 4 & $<2$ & 3 & 3 & 8 & 6 & 6 & 5 & 4 & 2 & 3 \\
\hline $\mathrm{Zn}$ & 11 & 51 & 43 & 10 & 40 & 91 & 49 & 87 & 126 & 49 & 197 \\
\hline $\mathrm{Cu}$ & 4 & 6 & 10 & $<2$ & 6 & 6 & 65 & 78 & 210 & 8 & 28 \\
\hline $\mathrm{Ni}$ & $<2$ & 8 & 5 & $<2$ & $<2$ & 1 & 4 & 72 & $<2$ & 6 & 19 \\
\hline $\mathrm{Cr}$ & 3 & 7 & 5 & 13 & 10 & $<2$ & 1 & 183 & 3 & 4 & 19 \\
\hline $\mathrm{Ba}$ & 151 & 130 & 303 & 174 & 754 & 570 & 896 & 403 & 468 & 287 & 1438 \\
\hline $\mathrm{Sc}^{*}$ & 4.8 & & 28 & $<1.8$ & $<1.8$ & 11 & 2.6 & 44 & 24 & 13 & 25 \\
\hline $\mathrm{V}^{*}$ & 55 & & 294 & 49 & 45 & 96 & 97 & 312 & 262 & 197 & 238 \\
\hline $\mathrm{Co}^{*}$ & 5.6 & & 18 & 5.3 & 2.86 & 8.7 & 7.2 & 38 & 23 & 15 & 23 \\
\hline $\mathrm{Mo}^{*}$ & 1.9 & & 1.6 & 0.6 & 0.7 & 0.7 & 1.1 & 0.7 & 0.8 & 1.0 & 0.7 \\
\hline $\mathrm{Cs}^{*}$ & 0.4 & & 0.7 & 0.4 & 0.6 & 1.2 & 0.7 & 1.8 & 1.2 & 3.3 & 0.3 \\
\hline $\mathrm{La}^{*}$ & 19 & & 15 & 22 & 15 & 16 & 20 & 14 & 17 & 10 & 13 \\
\hline $\mathrm{Ce}^{*}$ & 33 & & 29 & 36 & 25 & 37 & 38 & 29 & 38 & 21 & 27 \\
\hline $\mathrm{Pr}^{\star}$ & 3.5 & & 3.7 & 4.0 & 2.6 & 5.0 & 4.3 & 4.1 & 5.1 & 2.8 & 3.5 \\
\hline $\mathrm{Nd}^{*}$ & 13 & & 15 & 15 & 11 & 23 & 16 & 19 & 24 & 13 & 16 \\
\hline $\mathrm{Sm}^{\star}$ & 2.8 & & 3.9 & 3.2 & 2.2 & 5.9 & 3.6 & 5.0 & 5.8 & 3.0 & 4.0 \\
\hline $\mathrm{Eu}^{*}$ & 0.6 & & 1.0 & 0.8 & 0.6 & 1.6 & 1.0 & 1.5 & 1.7 & 1.0 & 1.2 \\
\hline $\mathrm{Gd}^{*}$ & 2.7 & & 4.2 & 3.2 & 1.7 & 5.9 & 2.8 & 4.9 & 5.8 & 3.1 & 4.1 \\
\hline $\mathrm{Tb}^{*}$ & 0.4 & & 0.6 & 0.5 & 0.3 & 1.0 & 0.4 & 0.6 & 0.9 & 0.5 & 0.7 \\
\hline $\mathrm{Dy}^{*}$ & 2.8 & & 3.8 & 3.6 & 1.5 & 6.3 & 2.4 & 3.8 & 5.7 & 3.3 & 4.7 \\
\hline $\mathrm{Ho}^{*}$ & 0.6 & & 0.8 & 0.7 & 0.3 & 1.3 & 0.5 & 0.7 & 1.2 & 0.6 & 1.0 \\
\hline $\mathrm{Er}^{*}$ & 1.9 & & 2.2 & 2.3 & 0.9 & 4.1 & 1.4 & 2.1 & 3.5 & 2.1 & 2.9 \\
\hline $\mathrm{Tm}^{*}$ & 0.3 & & 0.4 & 0.4 & 0.2 & 0.6 & 0.2 & 0.3 & 0.5 & 0.3 & 0.5 \\
\hline $\mathrm{Yb}^{*}$ & 2.3 & & 2.4 & 2.9 & 1.3 & 4.1 & 1.6 & 2.1 & 3.5 & 2.1 & 3.0 \\
\hline $\mathrm{Lu}^{*}$ & 0.4 & & 0.4 & 0.5 & 0.2 & 0.6 & 0.3 & 0.3 & 0.5 & 0.3 & 0.5 \\
\hline $\mathrm{Hf}^{\star}$ & 5.4 & & 2.7 & 6.4 & 3.2 & 3.5 & 2.7 & 2.1 & 3.3 & 2.6 & 3.0 \\
\hline $\mathrm{Ta}^{\star}$ & 0.7 & & 0.3 & 0.6 & 0.3 & 0.3 & 0.5 & 0.2 & 0.3 & 0.3 & 0.4 \\
\hline $\mathrm{W}^{\star}$ & 1.5 & & 1.9 & 2.3 & 0.8 & 0.6 & 1.0 & 0.4 & 0.7 & 0.3 & 1.0 \\
\hline $\mathrm{Th}^{*}$ & 14 & & 5.2 & 13 & 2.9 & 3.1 & 4.3 & 2.5 & 3.8 & 1.8 & 2.7 \\
\hline $\mathrm{U}^{*}$ & 2.6 & & 1.7 & 2.8 & 0.8 & 1.0 & 1.3 & 0.8 & 1.2 & 0.6 & 0.7 \\
\hline
\end{tabular}

Major elements in wt\% and trace elements in ppm. Major elements and trace elements from $\mathrm{Nb}$ to Ba were analysed by XRF, trace elements from Sc to U, marked with an asterisk ( ${ }^{*}$ ) were analysed by LA-ICP-MS. The ages of samples AG-10-06A, AG-10-07, KJ-12-07, KJ-10-02, $\mathrm{KJ}-12-11 \mathrm{~A}$ and $\mathrm{LI}-10-03$ identified by two asterisks ${\left({ }^{* \star}\right)}^{*}$ were obtained by U-Pb dating in this study. See Table 5 and Figure 18. Sample in italics were not used for petrogenetic classifications, because they were affected by hydrothermal alteration. 
Table 2: continued

\begin{tabular}{|c|c|c|c|c|c|c|c|c|c|c|}
\hline NAK-23 & DA-12-01 & KJ-09-1A & KJ-10-02 & KJ-10-06A & KJ-12-06 & KJ-12-07 & $\mathrm{KJ}-12-09 \mathrm{C}$ & NAK-9A & NAK-9B & NAK-10 \\
\hline Nakhitchevan & Dastakert & Kadjaran & Atkis & $\begin{array}{l}\text { Khustup-Giratakh } \\
\text { fault, Kadjaran }\end{array}$ & Meghri ridge & Meghri ridge & Meghri ridge & Nakhitchevan & Nakhitchevan & Nakhitchevan \\
\hline 3902.434 & 3911.939 & 3908.647 & 3909.584 & 3909.076 & 3906.169 & 3906.158 & 3907.547 & 3901.307 & 3901.307 & 3914.225 \\
\hline 4601.876 & 4615.609 & 4608.182 & 4609.528 & 4612.745 & 4613.283 & 4613.286 & 4609.804 & 4559.509 & 4559.509 & 4549.386 \\
\hline $\begin{array}{l}\text { Quartz } \\
\text { monzonite }\end{array}$ & $\begin{array}{l}\text { Qrtz syenite } \\
\text { (shoshonitic) }\end{array}$ & $\begin{array}{l}\text { Monzonite } \\
\text { (shoshonitic) }\end{array}$ & $\begin{array}{c}\text { Monzonite } \\
\text { (shoshonitic) }\end{array}$ & $\begin{array}{l}\text { Monzonite } \\
\text { (shoshonitic) }\end{array}$ & Granite & $\begin{array}{l}\text { Hornblende } \\
\text { gabbro }\end{array}$ & $\begin{array}{l}\text { Monzonite } \\
\text { (shoshonitic) }\end{array}$ & Monzodiorite & $\begin{array}{l}\text { Qrtz monzonite } \\
\quad \text { (adakitic) }\end{array}$ & Granite \\
\hline Eocene & Oligocene & Oligocene & $31.83 \pm 0.02^{\star \star}$ & Oligocene & Oligocene & $33.49 \pm 0.02^{\star \star}$ & Oligocene & Oligocene & Oligocene & Oligocene \\
\hline 60.87 & 64.48 & 55.55 & 56.86 & 57.09 & 68.76 & 42.07 & 55.63 & 52.46 & 61.97 & 64.97 \\
\hline 0.57 & 0.60 & 0.77 & 0.85 & 0.82 & 0.29 & 1.67 & 0.77 & 0.92 & 0.50 & 0.39 \\
\hline 17.45 & 17.06 & 19.50 & 17.66 & 18.62 & 15.33 & 18.50 & 19.09 & 17.82 & 16.74 & 17.01 \\
\hline 5.41 & 3.78 & 5.63 & 6.50 & 5.29 & 2.71 & 12.94 & 4.93 & 8.86 & 4.82 & 3.83 \\
\hline 0.12 & 0.12 & 0.09 & 0.13 & 0.12 & 0.05 & 0.20 & 0.09 & 0.16 & 0.10 & 0.02 \\
\hline 1.87 & 0.97 & 2.13 & 2.69 & 2.02 & 0.79 & 6.55 & 1.82 & 3.84 & 1.95 & 1.43 \\
\hline 4.89 & 2.91 & 6.07 & 4.97 & 4.00 & 2.78 & 12.84 & 5.65 & 8.40 & 5.34 & 2.90 \\
\hline 4.28 & 5.01 & 3.62 & 3.85 & 4.28 & 3.85 & 2.62 & 4.39 & 3.94 & 4.17 & 4.23 \\
\hline 2.91 & 4.34 & 4.58 & 4.63 & 6.05 & 4.60 & 0.64 & 4.76 & 1.95 & 3.07 & 3.13 \\
\hline 0.28 & 0.23 & 0.38 & 0.39 & 0.41 & 0.17 & 1.24 & 0.34 & 0.50 & 0.26 & 0.22 \\
\hline 0.62 & 0.39 & 0.71 & 0.55 & 0.71 & 0.27 & 0.68 & 2.07 & 0.46 & 0.21 & 1.00 \\
\hline 99.26 & 99.88 & 99.03 & 99.09 & 99.40 & 99.60 & 99.96 & 99.54 & 99.31 & 99.13 & 99.11 \\
\hline 4 & 12 & 8 & 37 & 39 & 21 & 11 & 14 & 10 & 9 & 10 \\
\hline 122 & 209 & 105 & 236 & 234 & 171 & 81 & 390 & 112 & 120 & 126 \\
\hline 23 & 26 & 24 & 25 & 21 & 19 & 40 & 16 & 24 & 14 & 24 \\
\hline 470 & 430 & 1083 & 749 & 706 & 707 & 1606 & 877 & 897 & 867 & 729 \\
\hline 62 & 109 & 123 & 162 & 206 & 133 & 15 & 99 & 57 & 102 & 81 \\
\hline 5 & 18 & 11 & 12 & 25 & 11 & 5 & 14 & 8 & 9 & 32 \\
\hline 34 & 44 & 47 & 66 & 78 & 23 & 100 & 52 & 55 & 34 & 38 \\
\hline 58 & 16 & 412 & 113 & 125 & 19 & 652 & 102 & 441 & 38 & 2527 \\
\hline 2 & 1 & 3 & 8 & 6 & 4 & 9 & 8 & 7 & 7 & 11 \\
\hline$<2$ & 0 & 7 & 11 & 8 & $<2$ & 2 & 11 & 6 & 13 & 7 \\
\hline 547 & 1099 & 2529 & 1066 & 903 & 1016 & 449 & 1484 & 614 & 860 & 1315 \\
\hline 8.4 & $<1.8$ & 11 & 12 & 6.5 & 2.7 & 31 & 9.0 & 23 & 6.1 & 4.6 \\
\hline 111 & 86 & 181 & 156 & 130 & 63 & 488 & 123 & 238 & 110 & 90 \\
\hline 9.3 & 6.70 & 13 & 13 & 11 & 4.9 & 43 & 12 & 19 & 10 & 8.3 \\
\hline 1.0 & 3.6 & 3.9 & 2.6 & 5.2 & 1.4 & 0.8 & 2.1 & 5.8 & 2.8 & 21 \\
\hline 0.5 & 1.7 & 2.0 & 2.5 & 3.3 & 1.5 & 0.7 & 1.2 & 0.7 & 1.3 & 2.2 \\
\hline 19 & 58 & 42 & 75 & 77 & 44 & 63 & 55 & 51 & 41 & 54 \\
\hline 38 & 98 & 71 & 130 & 129 & 90 & 135 & 87 & 95 & 71 & 99 \\
\hline 4.5 & 11 & 7.3 & 14 & 13 & 9.7 & 17 & 9.5 & 10 & 7.3 & 11 \\
\hline 19 & 38 & 28 & 52 & 50 & 34 & 73 & 36 & 41 & 27 & 46 \\
\hline 4.3 & 6.6 & 4.9 & 8.3 & 7.9 & 5.7 & 15 & 6.3 & 8.0 & 5.1 & 9.2 \\
\hline 1.3 & 1.7 & 2.1 & 1.9 & 2.1 & 1.3 & 3.5 & 2.0 & 1.8 & 1.2 & 2.4 \\
\hline 3.9 & 5.6 & 4.0 & 6.2 & 5.6 & 4.2 & 12 & 4.4 & 6.2 & 4.0 & 7.0 \\
\hline 0.6 & 0.9 & 0.5 & 0.8 & 0.7 & 0.6 & 1.4 & 0.6 & 0.8 & 0.5 & 1.0 \\
\hline 3.7 & 5.0 & 3.0 & 4.8 & 4.4 & 3.4 & 8.3 & 3.4 & 5.1 & 3.0 & 5.7 \\
\hline 0.8 & 1.1 & 0.6 & 1.0 & 0.8 & 0.7 & 1.5 & 0.7 & 1.0 & 0.6 & 1.2 \\
\hline 2.4 & 3.2 & 1.5 & 2.6 & 2.2 & 2.0 & 3.6 & 1.9 & 2.7 & 1.7 & 2.8 \\
\hline 0.3 & 0.5 & 0.2 & 0.4 & 0.4 & 0.4 & 0.5 & 0.3 & 0.4 & 0.2 & 0.5 \\
\hline 2.6 & 3.5 & 1.4 & 2.8 & 2.4 & 2.4 & 2.9 & 2.0 & 2.8 & 1.7 & 2.8 \\
\hline 0.4 & 0.6 & 0.2 & 0.4 & 0.4 & 0.4 & 0.4 & 0.3 & 0.5 & 0.3 & 0.4 \\
\hline 3.0 & 6.0 & 2.2 & 5.9 & 5.3 & 5.4 & 2.5 & 9.9 & 4.2 & 4.0 & 3.9 \\
\hline 0.3 & 1.0 & 0.4 & 1.8 & 1.8 & 1.8 & 0.5 & 0.6 & 0.6 & 0.8 & 0.8 \\
\hline 0.6 & 1.3 & 12.5 & 3.0 & 6.3 & 0.7 & 0.6 & 0.6 & 16.1 & 1.6 & 1.7 \\
\hline 5.4 & 18 & 5.2 & 34 & 20 & 36 & 3.7 & 6.3 & 9.3 & 15 & 20 \\
\hline 1.5 & 3.3 & 1.5 & 6.5 & 5.3 & 5.5 & 0.9 & 2.3 & 2.4 & 4.0 & 6.7 \\
\hline
\end{tabular}


Table 2: continued

\begin{tabular}{|c|c|c|c|c|c|c|c|c|c|c|}
\hline$N A K-11$ & NAK-12 & NAK-13 & NAK-16 & NAK-17 & NAK-18A & NAK-18C & NAK-19 & NAK-20 & $N A K-22$ & ROD7400 \\
\hline Nakhitchevan & Nakhitchevan & Nakhitchevan & Nakhitchevan & Nakhitchevan & Nakhitchevan & Nakhitchevan & Nakhitchevan & Nakhitchevan & Nakhitchevan & $\begin{array}{c}\text { Northern } \\
\text { Meghri pluton }\end{array}$ \\
\hline 3914.171 & 3912.935 & 3911.534 & 3902.408 & 3902.458 & 3903.477 & 3903.477 & 3903.561 & 3903.442 & 3902.840 & \\
\hline 4549.276 & 4544.478 & 4542.293 & 4601.925 & 4601.855 & 4602.665 & 4602.665 & 4602.828 & 4602.799 & 4601.834 & \\
\hline Altered granite & $\begin{array}{l}\text { Qrtz monzonite } \\
\quad \text { (adakitic) }\end{array}$ & $\begin{array}{l}\text { Qrtz monzonite } \\
\quad \text { (adakitic) }\end{array}$ & Granite & $\begin{array}{c}\text { Quartz } \\
\text { monzonite }\end{array}$ & $\begin{array}{l}\text { Monzodiorite } \\
\text { enclave }\end{array}$ & $\begin{array}{c}\text { Quartz } \\
\text { monzonite }\end{array}$ & $\begin{array}{l}\text { Qrtz monzonite } \\
\text { (adakitic) }\end{array}$ & $\begin{array}{l}\text { Monzodiorite } \\
\text { enclave }\end{array}$ & $\begin{array}{l}\text { Altered mafic } \\
\text { dike }\end{array}$ & $\begin{array}{c}\text { Monzonite } \\
\text { (shoshonitic) }\end{array}$ \\
\hline Oligocene & Oligocene & Oligocene & Oligocene & Oligocene & Oligocene & Oligocene & Oligocene & Oligocene & Oligocene & Oligocene \\
\hline 64.16 & 60.63 & 62.09 & 69.51 & 62.53 & 49.18 & 61.87 & 61.94 & 49.66 & 59.41 & 54.72 \\
\hline 0.43 & 0.54 & 0.44 & 0.29 & 0.55 & 1.15 & 0.57 & 0.53 & 0.86 & 0.72 & 0.75 \\
\hline 16.11 & 16.44 & 16.94 & 14.64 & 17.61 & 17.36 & 16.17 & 16.75 & 19.14 & 14.47 & 19.64 \\
\hline 4.47 & 4.83 & 4.67 & 2.65 & 5.02 & 9.54 & 5.26 & 4.68 & 10.61 & 5.44 & 7.32 \\
\hline 0.07 & 0.11 & 0.11 & 0.11 & 0.17 & 0.19 & 0.11 & 0.10 & 0.22 & 0.21 & 0.13 \\
\hline 1.82 & 2.83 & 2.12 & 0.79 & 1.78 & 6.17 & 2.26 & 2.04 & 3.53 & 4.75 & 2.50 \\
\hline 2.08 & 5.82 & 4.88 & 1.87 & 3.42 & 10.67 & 5.16 & 4.81 & 9.59 & 3.89 & 6.80 \\
\hline 2.98 & 4.29 & 4.49 & 3.34 & 4.97 & 3.31 & 3.82 & 4.07 & 4.08 & 3.42 & 3.55 \\
\hline 3.75 & 2.79 & 2.70 & 5.57 & 2.38 & 0.69 & 3.65 & 4.02 & 0.88 & 4.07 & 3.43 \\
\hline 0.31 & 0.30 & 0.25 & 0.09 & 0.28 & 0.24 & 0.28 & 0.25 & 0.46 & 0.41 & 0.44 \\
\hline 2.98 & 0.76 & 0.50 & 0.38 & 0.76 & 0.78 & 0.30 & 0.27 & 0.44 & 2.36 & 0.17 \\
\hline 99.17 & 99.34 & 99.17 & 99.24 & 99.47 & 99.30 & 99.46 & 99.46 & 99.47 & 99.20 & 99.44 \\
\hline 12 & 9 & 9 & 4 & 4 & 4 & 16 & 14 & 7 & 10 & 12 \\
\hline 130 & 109 & 113 & 100 & 130 & 97 & 175 & 203 & 90 & 139 & 119 \\
\hline 18 & 14 & 15 & 13 & 20 & 20 & 17 & 16 & 24 & 23 & 22 \\
\hline 554 & 860 & 850 & 291 & 355 & 924 & 613 & 736 & 1352 & 955 & 865 \\
\hline 92 & 79 & 85 & 100 & 45 & 19 & 91 & 116 & 17 & 93 & 92 \\
\hline 14 & 22 & 25 & 5 & 3 & 1 & 6 & 6 & $<2$ & 10 & 18 \\
\hline 44 & 47 & 47 & 48 & 70 & 62 & 33 & 31 & 73 & 108 & 84 \\
\hline 2095 & 40 & 22 & 4 & 5 & 71 & 25 & 13 & 38 & 72 & 121 \\
\hline 13 & 22 & 7 & 1 & 1 & 18 & 7 & 9 & 7 & 139 & 5 \\
\hline 30 & 48 & 7 & 1 & $<2$ & 16 & 8 & 17 & 4 & 195 & 6 \\
\hline 1417 & 1453 & 1438 & 1071 & 644 & 426 & 827 & 1049 & 570 & 1127 & 1422 \\
\hline 6.1 & 9.5 & 8.2 & & & & 9.8 & 9.8 & & 11 & 15 \\
\hline 98 & 124 & 111 & & & & 137 & 112 & & 121 & 182 \\
\hline 11 & 13 & 11 & & & & 12 & 10 & & 19 & 17 \\
\hline 63 & 0.8 & 1.1 & & & & 2.5 & 3.1 & & 1.3 & 3.2 \\
\hline 4.6 & 4.3 & 5.0 & & & & 0.8 & 1.3 & & 1.4 & 1.6 \\
\hline 66 & 44 & 44 & & & & 58 & 53 & & 49 & 37 \\
\hline 106 & 72 & 76 & & & & 92 & 85 & & 88 & 65 \\
\hline 11 & 7.7 & 8.0 & & & & 9.1 & 8.7 & & 10 & 7.8 \\
\hline 41 & 30 & 31 & & & & 32 & 31 & & 41 & 31 \\
\hline 6.8 & 5.3 & 5.1 & & & & 5.0 & 4.9 & & 7.4 & 6.5 \\
\hline 1.6 & 1.4 & 1.4 & & & & 1.3 & 1.3 & & 1.9 & 1.8 \\
\hline 5.4 & 3.9 & 4.2 & & & & 4.2 & 3.9 & & 5.2 & 5.5 \\
\hline 0.7 & 0.5 & 0.5 & & & & 0.6 & 0.5 & & 0.7 & 0.7 \\
\hline 3.9 & 3.0 & 3.2 & & & & 3.5 & 3.1 & & 4.1 & 4.4 \\
\hline 0.7 & 0.6 & 0.6 & & & & 0.7 & 0.7 & & 0.8 & 0.9 \\
\hline 2.1 & 1.6 & 1.8 & & & & 2.0 & 1.9 & & 2.2 & 2.5 \\
\hline 0.3 & 0.2 & 0.3 & & & & 0.3 & 0.3 & & 0.3 & 0.4 \\
\hline 1.9 & 1.6 & 1.9 & & & & 2.2 & 2.0 & & 2.5 & 2.3 \\
\hline 0.3 & 0.2 & 0.3 & & & & 0.4 & 0.3 & & 0.4 & 0.4 \\
\hline 4.2 & 3.1 & 3.4 & & & & 6.1 & 6.1 & & 3.8 & 3.5 \\
\hline 0.8 & 0.6 & 0.7 & & & & 1.3 & 1.0 & & 0.8 & 0.8 \\
\hline 7.0 & 1.8 & 1.5 & & & & 2.0 & 6.1 & & 1.1 & 1.0 \\
\hline 21 & 15 & 16 & & & & 38 & 26 & & 18 & 15 \\
\hline 4.3 & 5.4 & 6.1 & & & & 5.6 & 5.0 & & 5.0 & 4.3 \\
\hline
\end{tabular}


Table 2: continued

\begin{tabular}{|c|c|c|c|c|c|c|c|c|c|c|}
\hline$K J-09-1 B$ & $K J-10-06 B$ & $K J-12-02 C$ & $K J-12-03$ & $K J-12-04$ & $K J-12-05$ & $K J-12-09 A$ & $K J-12-09 B$ & KJ-09-02 & KJ-09-04A & KJ-09-04B \\
\hline Kadjaran & $\begin{array}{l}\text { Khustup-Giratakh } \\
\text { fault, Kadjaran }\end{array}$ & $\begin{array}{c}\text { Kadjaran } \\
\text { open pit }\end{array}$ & $\begin{array}{c}\text { Kadjaran open } \\
\text { pit }\end{array}$ & $\begin{array}{c}\text { Kadjaran open } \\
\text { pit }\end{array}$ & $\begin{array}{c}\text { Kadjaran open } \\
\text { pit }\end{array}$ & Meghri ridge & Meghri ridge & Kadjaran & $\begin{array}{c}\text { Kadjaran, } \\
\text { Voghchi sec. }\end{array}$ & $\begin{array}{c}\text { Kadjaran, } \\
\text { Voghchi sec. }\end{array}$ \\
\hline 3908.647 & 3906.169 & 3908.647 & 3908.643 & 3908.634 & 3908.610 & 3907.547 & 3907.547 & 3909.465 & 3909.578 & 3909.578 \\
\hline 4608.182 & 4613.283 & 4608.182 & 4608.206 & 4608.235 & 4608.316 & 4609.804 & 4609.804 & 4606.855 & 4612.196 & 4612.196 \\
\hline $\begin{array}{l}\text { Porphyritic qtz } \\
\text { monzonitic dike }\end{array}$ & $\begin{array}{l}\text { Porphyritic qtz } \\
\text { monzonitic dike }\end{array}$ & Altered dike & $\begin{array}{l}\text { Porphyritic qtz } \\
\text { monzonitic dike }\end{array}$ & $\begin{array}{l}\text { Porphyritic qtz } \\
\text { monzonitic dike }\end{array}$ & $\begin{array}{l}\text { Porphyritic qtz } \\
\text { monzonitic dike }\end{array}$ & $\begin{array}{l}\text { Porphyritic qtz } \\
\text { monzonitic dike }\end{array}$ & $\begin{array}{l}\text { Porphyritic qtz } \\
\text { monzonitic dike }\end{array}$ & Granite & $\begin{array}{l}\text { Porphyritic qtz } \\
\text { monzonitic dike }\end{array}$ & $\begin{array}{l}\text { Porphyritic qtz } \\
\text { monzonitic dike }\end{array}$ \\
\hline Oligo-Miocene & Oligo-Miocene & Oligo-Miocene & Oligo-Miocene & Oligo-Miocene & Oligo-Miocene & Oligo-Miocene & Oligo-Miocene & Miocene & Miocene & Miocene \\
\hline 64.49 & 53.21 & 58.76 & 62.46 & 63.16 & 61.64 & 56.76 & 51.53 & 70.24 & 64.95 & 52.49 \\
\hline 0.41 & 1.29 & 0.69 & 0.45 & 0.42 & 0.49 & 0.68 & 1.02 & 0.26 & 0.52 & 1.05 \\
\hline 14.58 & 14.61 & 18.04 & 14.23 & 14.34 & 14.57 & 14.87 & 14.14 & 14.69 & 15.52 & 18.82 \\
\hline 2.92 & 7.05 & 4.68 & 3.36 & 3.04 & 3.18 & 5.39 & 6.23 & 2.02 & 3.66 & 9.46 \\
\hline 0.06 & 0.10 & 0.04 & 0.06 & 0.06 & 0.08 & 0.10 & 0.11 & 0.05 & 0.07 & 0.19 \\
\hline 1.45 & 5.07 & 1.09 & 1.67 & 1.76 & 2.18 & 4.46 & 6.06 & 0.72 & 2.36 & 5.20 \\
\hline 3.07 & 6.04 & 2.21 & 3.63 & 3.41 & 4.86 & 5.92 & 6.78 & 2.25 & 3.18 & 4.85 \\
\hline 0.00 & 3.60 & 3.40 & 2.65 & 2.55 & 0.07 & 4.10 & 3.08 & 3.97 & 4.18 & 4.83 \\
\hline 5.30 & 3.67 & 8.02 & 3.63 & 4.62 & 1.02 & 3.00 & 3.57 & 4.30 & 3.94 & 0.35 \\
\hline 0.19 & 0.41 & 0.23 & 0.21 & 0.21 & 0.25 & 0.33 & 0.58 & 0.13 & 0.28 & 0.23 \\
\hline 7.26 & 4.54 & 2.28 & 7.25 & 6.70 & 11.54 & 3.99 & 6.80 & 0.47 & 0.96 & 1.94 \\
\hline 99.73 & 99.63 & 99.45 & 99.62 & 100.27 & 99.87 & 99.63 & 99.93 & 99.09 & 99.64 & 99.40 \\
\hline 11 & 20 & 15 & 10 & 10 & 10 & 9 & 19 & 13 & 14 & 15 \\
\hline 144 & 209 & 1031 & 113 & 105 & 113 & 122 & 155 & 105 & 109 & 112 \\
\hline 15 & 15 & 16 & 10 & 9 & 10 & 13 & 17 & 12 & 15 & 16 \\
\hline 230 & 790 & 375 & 345 & 394 & 248 & 711 & 588 & 653 & 718 & 653 \\
\hline 219 & 122 & 182 & 118 & 153 & 46 & 71 & 81 & 163 & 113 & 103 \\
\hline 24 & 6 & 14 & 36 & 61 & 17 & 12 & 13 & 15 & 18 & 10 \\
\hline 63 & 69 & 26 & 77 & 74 & 49 & 54 & 61 & 28 & 56 & 45 \\
\hline 32 & 73 & 308 & 23 & 45 & 24 & 66 & 42 & $<2$ & 29 & 27 \\
\hline 21 & 117 & 2 & 30 & 27 & 24 & 84 & 125 & 6 & 34 & 40 \\
\hline 39 & 418 & 0 & 40 & 40 & 44 & 144 & 188 & 10 & 68 & 100 \\
\hline 852 & 788 & 904 & 658 & 670 & 435 & 744 & 633 & 998 & 869 & 838 \\
\hline 6.8 & 11 & 5.4 & 5.4 & 5.8 & 5.6 & 6.7 & 13 & 3.7 & 7.9 & \\
\hline 81 & 160 & 95 & 77 & 77 & 88 & 137 & 158 & 60 & 97 & \\
\hline 8.0 & 27 & 9.9 & 9.3 & 9.1 & 10 & 20 & 25 & 4.0 & 12 & \\
\hline 1.1 & 1.7 & 11 & 4.1 & 2.4 & 3.1 & 1.0 & 3.4 & 1.0 & 1.1 & \\
\hline 6.9 & 2.0 & 3.9 & 7.5 & 9.6 & 3.5 & 1.0 & 2.3 & 2.1 & 1.1 & \\
\hline 32 & 38 & 41 & 33 & 35 & 35 & 41 & 51 & 39 & 37 & \\
\hline 49 & 73 & 74 & 58 & 58 & 58 & 69 & 89 & 56 & 58 & \\
\hline 4.6 & 8.2 & 7.9 & 5.7 & 5.6 & 5.8 & 7.5 & 9.8 & 5.1 & 6.1 & \\
\hline 16 & 32 & 29 & 20 & 19 & 20 & 30 & 39 & 18 & 20 & \\
\hline 2.8 & 5.9 & 5.1 & 3.2 & 3.2 & 3.4 & 5.6 & 6.6 & 2.7 & 3.6 & \\
\hline 0.7 & 1.6 & 1.6 & 0.9 & 0.8 & 0.9 & 1.4 & 1.9 & 0.8 & 1.0 & \\
\hline 2.0 & 4.9 & 3.9 & 2.5 & 2.4 & 2.6 & 4.0 & 5.4 & 1.7 & 2.6 & \\
\hline 0.3 & 0.6 & 0.5 & 0.3 & 0.3 & 0.3 & 0.6 & 0.7 & 0.2 & 0.4 & \\
\hline 1.6 & 3.2 & 3.1 & 2.1 & 1.8 & 1.9 & 3.0 & 3.7 & 1.3 & 1.9 & \\
\hline 0.3 & 0.6 & 0.6 & 0.4 & 0.4 & 0.4 & 0.5 & 0.7 & 0.3 & 0.3 & \\
\hline 0.8 & 1.6 & 1.9 & 1.0 & 0.9 & 1.0 & 1.5 & 1.8 & 0.6 & 0.9 & \\
\hline 0.1 & 0.2 & 0.3 & 0.2 & 0.1 & 0.1 & 0.2 & 0.3 & 0.1 & 0.1 & \\
\hline 1.0 & 1.5 & 2.6 & 1.2 & 1.0 & 1.1 & 1.5 & 1.7 & 0.7 & 0.9 & \\
\hline 0.1 & 0.2 & 0.4 & 0.2 & 0.2 & 0.2 & 0.2 & 0.3 & 0.1 & 0.2 & \\
\hline 2.9 & 4.4 & 26 & 3.3 & 3.3 & 3.1 & 3.6 & 4.3 & 3.5 & 3.0 & \\
\hline 0.8 & 1.2 & 0.5 & 0.9 & 0.9 & 0.9 & 0.8 & 1.4 & 0.8 & 0.9 & \\
\hline 7.4 & 1.5 & 9.2 & 8.5 & 4.4 & 5.4 & 0.9 & 1.1 & 1.1 & 1.6 & \\
\hline 17 & 13 & 7.9 & 18 & 19 & 18 & 16 & 15 & 23 & 19 & \\
\hline 4.2 & 4.3 & 5.7 & 4.2 & 6.4 & 3.9 & 5.5 & 5.0 & 8.1 & 5.2 & \\
\hline
\end{tabular}


Table 2: continued

\begin{tabular}{|c|c|c|c|c|c|c|c|c|}
\hline KJ-10-04 & KJ-10-05 & KJ-10-09 & $K J-12-11 A$ & LI-10-01 & LI-10-02A & LI-10-03 & NAK-18D & LI-10-04 \\
\hline $\begin{array}{l}\text { Kadjaran, } \\
\text { Katudjur river }\end{array}$ & $\begin{array}{c}\text { Kadjaran, } \\
\text { Katudjur river }\end{array}$ & $\begin{array}{l}\text { Khustup-Giratakh } \\
\text { fault, Kadjaran }\end{array}$ & $\begin{array}{l}\text { Kadjaran } \\
\text { open pit }\end{array}$ & Djband & $\begin{array}{l}\text { Lichk } \\
\text { prospect }\end{array}$ & $\begin{array}{l}\text { Lichk } \\
\text { prospect }\end{array}$ & Nakhitchevan & Lichk area \\
\hline 3909.432 & 3909.460 & 3908.381 & 3908.610 & 3905.637 & 3902.889 & 3902.777 & 3903.477 & 3902.310 \\
\hline 4606.707 & 4606.850 & 4612.859 & 4608.316 & 4610.192 & 4610.699 & 4610.375 & 4602.665 & 4612.174 \\
\hline Granite & Granite & Monzonite & $\begin{array}{c}\text { Granodioritic } \\
\text { dike }\end{array}$ & $\begin{array}{l}\text { Porphyritic qtz } \\
\text { monzonitic dike }\end{array}$ & Granite & Granite & $\begin{array}{l}\text { Porphyritic qtz } \\
\text { monzonitic dike }\end{array}$ & Dacite \\
\hline Miocene & Miocene & Miocene & $22.46 \pm 0.02^{* \star}$ & Miocene & Miocene & $22.22 \pm 0.01^{\star *}$ & Miocene & Pliocene \\
\hline 70.78 & 70.14 & 62.86 & 54.26 & 65.09 & 64.69 & 66.97 & 65.03 & 65.04 \\
\hline 0.24 & 0.27 & 0.31 & 0.54 & 0.50 & 0.46 & 0.48 & 0.54 & 0.59 \\
\hline 14.83 & 15.41 & 19.99 & 15.06 & 15.07 & 15.21 & 15.26 & 15.02 & 15.81 \\
\hline 1.95 & 2.20 & 2.13 & 3.92 & 3.54 & 3.01 & 3.35 & 3.87 & 4.12 \\
\hline 0.04 & 0.05 & 0.03 & 0.11 & 0.06 & 0.03 & 0.05 & 0.06 & 0.08 \\
\hline 0.73 & 0.92 & 0.53 & 2.82 & 2.15 & 1.69 & 2.06 & 2.55 & 2.20 \\
\hline 2.13 & 2.61 & 4.34 & 5.98 & 3.28 & 3.83 & 3.19 & 2.92 & 3.52 \\
\hline 4.00 & 4.09 & 4.41 & 0.17 & 3.54 & 3.75 & 3.88 & 4.10 & 3.78 \\
\hline 4.11 & 3.63 & 4.19 & 4.59 & 4.18 & 3.52 & 3.50 & 3.63 & 3.72 \\
\hline 0.11 & 0.13 & 0.13 & 0.28 & 0.25 & 0.21 & 0.21 & 0.27 & 0.28 \\
\hline 0.20 & 0.32 & 0.49 & 11.95 & 1.92 & 2.75 & 0.60 & 1.12 & 0.73 \\
\hline 99.11 & 99.77 & 99.40 & 99.69 & 99.59 & 99.17 & 99.55 & 99.12 & 99.90 \\
\hline 12 & 10 & 16 & 11 & 13 & 11 & 15 & 12 & 14 \\
\hline 130 & 135 & 181 & 102 & 135 & 137 & 111 & 111 & 154 \\
\hline 7.1 & 7.6 & 13 & 11 & 10 & 9.2 & 10 & 11 & 12 \\
\hline 668 & 735 & 719 & 274 & 678 & 837 & 670 & 701 & 799 \\
\hline 156 & 120 & 120 & 149 & 131 & 79 & 100 & 97 & 101 \\
\hline 17 & 18 & 16 & 29 & 11 & 8 & 9 & 11 & 16 \\
\hline 27 & 31 & 31 & 71 & 42 & 46 & 40 & 42 & 62 \\
\hline 5 & 5 & 28 & 42 & 25 & 912 & 18 & 48 & 43 \\
\hline 7 & 8 & 2 & 28 & 49 & 37 & 39 & 44 & 50 \\
\hline 8 & 10 & 3 & 60 & 80 & 48 & 58 & 65 & 70 \\
\hline 998 & 960 & 1167 & 778 & 770 & 729 & 725 & 717 & 927 \\
\hline$<1.08$ & $<1.08$ & 6.4 & 4.5 & 4.9 & 5.9 & 5.6 & 8.3 & 6.5 \\
\hline 51 & 53 & 60 & 98 & 88 & 83 & 86 & 93 & 101 \\
\hline 4.7 & 4.6 & 5.3 & 12 & 11 & 8.4 & 9.7 & 12 & 13 \\
\hline 0.8 & 1.4 & 1.6 & 6.8 & 3.3 & 11 & 2.0 & 0.7 & 0.9 \\
\hline 1.9 & 1.6 & 2.3 & 2.9 & 3.7 & 0.7 & 1.3 & 0.7 & 1.3 \\
\hline 38 & 31 & 43 & 40 & 41 & 31 & 38 & 42 & 39 \\
\hline 57 & 51 & 69 & 59 & 61 & 53 & 61 & 65 & 64 \\
\hline 5.5 & 5.0 & 6.5 & 6.4 & 6.9 & 5.9 & 6.6 & 6.8 & 7.3 \\
\hline 19 & 18 & 21 & 24 & 25 & 22 & 23 & 25 & 26 \\
\hline 3.3 & 3.0 & 4.7 & 4.2 & 4.2 & 3.9 & 4.0 & 3.9 & 4.6 \\
\hline 0.8 & 0.8 & 1.6 & 1.2 & 1.1 & 1.1 & 1.0 & 1.1 & 1.2 \\
\hline 2.3 & 2.2 & 3.6 & 3.2 & 3.0 & 2.8 & 3.0 & 3.0 & 3.3 \\
\hline 0.3 & 0.3 & 0.5 & 0.4 & 0.4 & 0.3 & 0.4 & 0.4 & 0.4 \\
\hline 1.7 & 1.6 & 2.7 & 2.6 & 2.3 & 1.9 & 2.2 & 2.5 & 2.3 \\
\hline 0.3 & 0.3 & 0.5 & 0.5 & 0.4 & 0.3 & 0.4 & 0.5 & 0.4 \\
\hline 0.9 & 0.8 & 1.7 & 1.2 & 1.1 & 1.0 & 1.1 & 1.3 & 1.2 \\
\hline 0.1 & 0.1 & 0.2 & 0.2 & 0.2 & 0.1 & 0.2 & 0.2 & 0.2 \\
\hline 0.9 & 1.0 & 1.8 & 1.4 & 1.3 & 1.0 & 1.3 & 1.4 & 1.2 \\
\hline 0.2 & 0.2 & 0.3 & 0.2 & 0.2 & 0.1 & 0.2 & 0.2 & 0.2 \\
\hline 4.1 & 3.2 & 5.8 & 3.7 & 4.1 & 3.3 & 3.7 & 3.9 & 3.9 \\
\hline 1.0 & 0.7 & 1.2 & 1.0 & 1.3 & 0.8 & 1.2 & 1.1 & 1.1 \\
\hline 0.5 & 0.6 & 10.8 & 7.6 & 2.6 & 8.1 & 0.9 & 1.3 & 0.8 \\
\hline 24 & 22 & 23 & 19 & 25 & 17 & 23 & 23 & 19 \\
\hline 3.9 & 4.5 & 5.9 & 14.5 & 5.9 & 6.1 & 6.7 & 5.7 & 6.3 \\
\hline
\end{tabular}


Table 3 - Detailed petrographic descriptions of representative magmatic rocks from the composite Meghri-Ordubad pluton (see thin-section plates in Figure 7 and locations in Figure $3 b$ )

\begin{tabular}{|c|c|c|c|c|c|c|c|c|}
\hline Sample & Location & Longitude & Latitude & Altitude (m) & Age (Ma) & Rock type (TAS) & Texture & Mineralogy and percentage (vol\%) \\
\hline AG-10-03 & Agarak area & E46 11.684 & N38 53.844 & 947 & Eocene & Granodiorite & Equigranular & $\begin{array}{c}35 \% \text { quartz, } 20 \% \text { plagioclase, } 25 \% \text { K-feldspar, } \\
5 \% \text { interstitial schredy biotite and chlorite. }\end{array}$ \\
\hline AG-10-07 & Agarak area & E46 13.274 & N38 53.862 & 849 & $44.03 \pm 0.02$ & Granite & Equigranular & $\begin{array}{c}35 \% \text { quartz, } 35 \% \text { plagioclase, } 15 \% \text { amphibole, } \\
2 \% \text { biotite, } 2 \% \text { K-feldspar (myrmekitic). } \\
\text { Accessory minerals: apatite, sphene, zircons, } \\
\text { oxides }\end{array}$ \\
\hline AG-10-04 & Agarak area & E46 11.705 & N38 53.831 & 949 & Eocene & Trachybasalt & Porphyritic & $\begin{array}{l}\text { Phenocrysts: } 10 \% \text { plagioclase; Matrix: } 70 \% \\
\text { plagioclase (fine laths), } 10-15 \% \text { pyroxene. } \\
\text { Accessory mineral: oxide (magnetite) }\end{array}$ \\
\hline KJ-12-07 & Meghri ridge & E46 13.286 & N39 06.158 & 2693 & $33.49 \pm 0.02$ & $\begin{array}{l}\text { Hornblende } \\
\text { gabbro }\end{array}$ & Equigranular & $\begin{array}{c}40 \% \text { amphibole with resorbed clinopyroxene } \\
\text { core, } 35 \% \text { plagioclase, } 5 \% \text { biotite, } 2 \% \text { apatite. } \\
\text { Accessory minerals: sphene, zircons, rutile, } \\
\text { oxides }\end{array}$ \\
\hline KJ-10-06A & $\begin{array}{c}\text { East of Kadjaran } \\
\text { and Atkis area }\end{array}$ & E46 12.745 & N39 09.076 & 1662 & Oligocene & Monzonite & Equigranular & $\begin{array}{c}30 \% \text { K-feldspar (myrmekitic), } 15 \% \text { amphibole } \\
\text { surrounding clinopyroxene, } 10 \% \text { plagioclase, } \\
\text { and } 20 \% \text { interstitial quartz and schredy biotite. } \\
\text { Accessory minerals: apatite, sphene, zircons, } \\
\text { rutile. oxides }\end{array}$ \\
\hline KJ-09-02 & $\begin{array}{l}\text { Kadjaran area, } \\
\text { Katudjur river }\end{array}$ & E46 06.850 & N39 09.460 & 1975 & Miocene & Granite & Equigranular & $\begin{array}{c}30 \% \text { quartz, } 35 \% \text { K-feldspar with poekilitic } \\
\text { texture and coarse grains, } 5 \% \text { plagioclase, } 5 \% \\
\text { amphibole, } 2 \% \text { biotite, } 1 \% \text { sphene. Accessory } \\
\text { minerals: oxides, zircons }\end{array}$ \\
\hline KJ-09-04B & $\begin{array}{l}\text { Vogchi section, } \\
\text { road Kadjaran to } \\
\text { Kapan }\end{array}$ & E46 12.196 & N39 09.578 & 1547 & Miocene & Monzonite & Porphyritic & $\begin{array}{l}\text { Phenocryst: } 20 \% \text { plagioclase (sericitized), 15\% } \\
\text { amphibole (biotitized-chloritized), } 5 \% \text { biotite } \\
\text { (chloritized), } 5 \% \text { quartz; aphanitic matrix (55\%) }\end{array}$ \\
\hline LI-10-04 & Lichk area & E46 12.174 & N39 02.310 & 1509 & Pliocene & Dacite & Porphyritic & $\begin{array}{c}\text { Phenocryst: } 20 \% \text { plagioclase, } 10 \% \text { amphibole, } \\
\text { and } 5 \% \text { biotite (with opaque rim). Accessory } \\
\text { minerals: apatite, zircons, oxides. } \\
\text { Microcrystalline quartz-plagioclase matrix ( } 60 \%)\end{array}$ \\
\hline
\end{tabular}


Table 4 - Isotope data of magmatic whole rock samples from the composite Meghri-Ordubad pluton

\begin{tabular}{|c|c|c|c|c|c|c|c|c|c|c|c|c|}
\hline Sample & Age (Ma) & ${ }^{87} \mathrm{Sr} /{ }^{86} \mathrm{Sr}$ & ${ }^{87} \mathrm{Sr} /{ }^{86} \mathrm{Sr}_{\mathrm{i}}$ & ${ }^{143} \mathrm{Nd} /{ }^{144} \mathrm{Nd}$ & ${ }^{143} \mathrm{Nd} /{ }^{144} \mathrm{Nd}_{\mathrm{i}}$ & ${ }^{206} \mathrm{~Pb} /{ }^{204} \mathrm{~Pb}$ & ${ }^{207} \mathrm{~Pb} /{ }^{204} \mathrm{~Pb}$ & ${ }^{208} \mathrm{~Pb} /{ }^{204} \mathrm{~Pb}$ & ${ }^{206} \mathrm{~Pb} /{ }^{204} \mathrm{~Pb}_{\mathrm{i}}$ & ${ }^{207} \mathrm{~Pb} /{ }^{204} \mathrm{~Pb}_{\mathrm{i}}$ & ${ }^{208} \mathrm{~Pb} /{ }^{204} \mathrm{~Pb}_{\mathrm{i}}$ & $\delta^{18} \mathrm{O}(\%)$ \\
\hline AG-10-06A* & 48.99 & 0.704721 & 0.704629 & 0.512791 & 0.512754 & 19.034 & 15.581 & 39.187 & 18.995 & 15.579 & 39.134 & 5.70 \\
\hline AG-10-07* & 44.03 & 0.704356 & 0.704252 & 0.512772 & 0.512740 & 18.617 & 15.578 & 38.645 & 18.583 & 15.576 & 38.596 & 7.02 \\
\hline AG-10-03** & Eocene & 0.704648 & 0.704571 & 0.512789 & 0.512756 & 19.012 & 15.602 & 39.267 & 18.751 & 15.590 & 38.608 & 6.20 \\
\hline AG-10-04** & Eocene & 0.704897 & 0.704608 & 0.512789 & 0.512743 & 18.671 & 15.557 & 38.494 & 18.492 & 15.549 & 38.429 & 3.68 \\
\hline $\mathrm{KJ}-10-03^{\star *}$ & Eocene & 0.704401 & 0.704206 & 0.512827 & 0.512785 & 18.503 & 15.579 & 38.555 & 18.437 & 15.576 & 38.483 & 3.80 \\
\hline $\mathrm{KJ}-10-10^{\star *}$ & Eocene & 0.704505 & 0.704335 & 0.512794 & 0.512753 & 18.708 & 15.584 & 38.660 & 18.608 & 15.579 & 38.539 & \\
\hline KJ-10-06A** & Oligocene & 0.704309 & 0.703926 & 0.512810 & 0.512790 & 18.869 & 15.575 & 38.863 & 18.812 & 15.572 & 38.793 & 5.55 \\
\hline ROD $7400^{* *}$ & Oligocene & 0.704167 & 0.704027 & 0.512797 & 0.512774 & 18.665 & 15.523 & 38.612 & 18.596 & 15.520 & 38.527 & 6.49 \\
\hline KJ-10-02* & 31.82 & 0.704248 & 0.703965 & 0.512837 & 0.512817 & & & & & & & 6.17 \\
\hline LI-10-03* & 22.22 & 0.704292 & 0.704155 & 0.512814 & 0.512799 & 19.094 & 15.561 & 38.902 & 18.988 & 15.556 & 38.759 & 7.62 \\
\hline $\mathrm{KJ}-10-04^{* *}$ & Miocene & 0.704363 & 0.704152 & 0.512820 & 0.512807 & 19.128 & 15.603 & 39.048 & 19.087 & 15.602 & 38.954 & 6.91 \\
\hline KJ-09-04A** & Miocene & 0.704496 & 0.704354 & 0.512845 & 0.512831 & 18.999 & 15.586 & 38.934 & 18.936 & 15.583 & 38.853 & 6.15 \\
\hline KJ-10-09** & Miocene & 0.704187 & 0.704037 & 0.512814 & 0.512800 & 18.899 & 15.540 & 38.783 & 18.804 & 15.536 & 38.664 & 6.89 \\
\hline LI-10-01** & Miocene & 0.704338 & 0.704164 & 0.512860 & 0.512845 & 19.062 & 15.540 & 38.867 & 18.968 & 15.536 & 38.727 & 8.34 \\
\hline LI-10-02A** & Miocene & 0.704178 & 0.704097 & 0.512824 & 0.512810 & 19.032 & 15.539 & 38.833 & 18.899 & 15.532 & 38.694 & \\
\hline LI-10-04** & Pliocene & 0.704223 & 0.704202 & 0.512841 & 0.512838 & 18.983 & 15.546 & 38.822 & 18.969 & 15.546 & 38.807 & 6.03 \\
\hline
\end{tabular}

* The ages of samples AG-10-06A, AG-10-07, KJ-10-02 and LI-10-03 were obtained by U-Pb dating in this study. See Table 5 and Figure 18.

** Ages of $44 \mathrm{Ma}, 32 \mathrm{Ma}, 22 \mathrm{Ma}$, and $4 \mathrm{Ma}$ were used for age corrections of the Eocene, Oligocene, Miocene and Pliocene magmatic rocks, respectively.

Trace element data used for age corrections of radiogenic isotope ratios can be found in Table 2 ( $\mathrm{Sr}, \mathrm{Rb}, \mathrm{Sm}, \mathrm{Nd}, \mathrm{Pb}, \mathrm{U}$ and $\mathrm{Th}$ ). 
Table 5 - TIMS zircon dating of samples from the composite Meghri-Ordubad pluton (see Figure $3 \mathrm{~b}$ for sample location and Figure 18 for Concordia diagrams and ${ }^{206} \mathrm{~Pb} / 23 \mathrm{U}$ plots)

\begin{tabular}{|c|c|c|c|c|c|c|c|c|c|c|c|c|c|c|c|c|c|c|c|c|}
\hline \multirow{3}{*}{$\underset{\text { Sample }}{\text { (a) }}$} & \multirow{3}{*}{$\begin{array}{l}\text { Wt. } \\
\text { mg } \\
\text { (o) }\end{array}$} & \multicolumn{6}{|c|}{ Compositional Parameters } & \multicolumn{7}{|c|}{ Radiogenic Isotope Ratios } & \multirow{2}{*}{\multicolumn{6}{|c|}{ Isotopic Ages }} \\
\hline & & 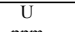 & Th & & $\frac{\mathrm{Pb} *}{\mathrm{~Pb}}$ & $\mathrm{~Pb}_{\mathrm{e}}$ & 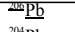 & $=\mathrm{pl}$ & & & & & & corr. & $=\underline{P b}$ & & & & 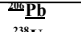 & \\
\hline & & ppm & $\begin{array}{l}\mathrm{U} \\
\text { (a) } \\
\end{array}$ & $\begin{array}{c}\mathrm{ppm} \\
(\mathrm{c}) \\
\end{array}$ & $\begin{array}{l}\mathrm{Pb}_{\mathrm{e}} \\
(\mathrm{e})\end{array}$ & $\begin{array}{l}(\mathrm{pg}) \\
\mathrm{ge})\end{array}$ & (II) & $\begin{array}{l}2006 \mathrm{~b} \\
\text { (g) }\end{array}$ & $\begin{array}{c}\text { \% err } \\
\text { (n) }\end{array}$ & $\begin{array}{l}2.3 \mathrm{U} \\
\text { (g) }\end{array}$ & $\begin{array}{c}\text { \%err } \\
\text { (n) }\end{array}$ & $\begin{array}{l}2.8, \mathrm{U} \\
\text { (g) }\end{array}$ & $\begin{array}{c}\text { \% err } \\
\text { (n) }\end{array}$ & coef. & (I) & (n) & $\begin{array}{lll}233 \\
\text { (1) }\end{array}$ & (n) & $\begin{array}{l}28, \mathrm{U} \\
\text { (II) }\end{array}$ & (in) \\
\hline \multicolumn{21}{|c|}{$\begin{array}{l}\text { granodiorite } A G-10-06 A \\
\end{array}$} \\
\hline & & 514 & 0.78 & 5.69 & 3.30 & 0.93 & 203 & 0.0470 & 1.25 & 0.04944 & 1.35 & 0.007629 & 0.14 & 0.77 & 49.37 & 29.72 & 49.00 & 0.64 & 48.99 & 0.07 \\
\hline AG-10-06A/5 & 0.0020 & 315 & 0.71 & 3.11 & 5.90 & 0.90 & 355 & 0.0471 & 0.78 & 0.04989 & 0.82 & 0.007691 & 0.09 & 0.44 & 51.95 & 18.65 & 49.44 & 0.39 & 49.39 & 0.05 \\
\hline $\begin{array}{l}\text { AG-10-06A/6 } \\
A G-10.092\end{array}$ & 0.0010 & 242 & 0.85 & 3.30 & 1.80 & 1.18 & 118 & 0.0473 & 2.09 & 0.05028 & 2.16 & 0.007711 & 0.23 & 0.36 & 63.84 & 49.84 & 49.81 & 1.05 & 49.52 & 0.11 \\
\hline $\begin{array}{l}\text { AG-10-00A/2 } \\
\text { AG-10-06A/3/3 }\end{array}$ & $\begin{array}{l}0.0001 \\
0.0001\end{array}-150$ & $\begin{array}{l}4223 \\
1835\end{array}$ & $\begin{array}{l}1.07 \\
1.39\end{array}$ & $\begin{array}{l}47.17 \\
22.84\end{array}$ & $\begin{array}{l}4.74 \\
1.93 \\
\end{array}$ & $\begin{array}{l}0.82 \\
0.95\end{array}$ & $\begin{array}{l}266 \\
112\end{array}$ & & $\begin{array}{l}1.09 \\
3.01\end{array}$ & $\begin{array}{l}0.05045 \\
0.05063\end{array}$ & $\begin{array}{l}1.13 \\
3.13\end{array}$ & $\begin{array}{l}0.007696 \\
0.00764\end{array}$ & & $\begin{array}{l}0.33 \\
0.39\end{array}$ & $\begin{array}{l}76.75 \\
64.39\end{array}$ & 25.89 & $\begin{array}{c}49.98 \\
50.15\end{array}$ & 0.55 & 49.42 & 0.07 \\
\hline $\begin{array}{l}\mathrm{AG}-10-00 \mathrm{AA} / 3 \\
\mathrm{AG}-10-06 \mathrm{~A} / 4\end{array}$ & $\begin{array}{l}0.0001 \\
0.0001\end{array}$ & $\begin{array}{l}1835 \\
4627\end{array}$ & $\begin{array}{l}1.39 \\
0.99\end{array}$ & $\begin{array}{l}27.84 \\
53.51\end{array}$ & $\begin{array}{l}1.93 \\
3.62\end{array}$ & $\begin{array}{l}0.95 \\
1.16\end{array}$ & $\begin{array}{l}112 \\
211\end{array}$ & $\begin{array}{l}0.0473 \\
0.0476\end{array}$ & $\begin{array}{l}3.01 \\
1.26\end{array}$ & $\begin{array}{l}0.0303 \\
0.05054\end{array}$ & $\begin{array}{l}3.13 \\
1.35\end{array}$ & $\begin{array}{l}0.00764 \\
0.007694\end{array}$ & $\begin{array}{l}0.34 \\
0.17\end{array}$ & $\begin{array}{l}0.39 \\
0.55\end{array}$ & $\begin{array}{l}64.39 \\
81.55\end{array}$ & $\begin{array}{r}11.14 \\
29.88\end{array}$ & $\begin{array}{l}50.13 \\
50.06\end{array}$ & $\begin{array}{l}1.53 \\
0.66\end{array}$ & $\begin{array}{l}49.86 \\
49.41\end{array}$ & $\begin{array}{l}0.17 \\
0.08\end{array}$ \\
\hline \multicolumn{21}{|c|}{$\begin{array}{l}\text { granite } A G-10-07 \\
\text { AG-10-07/3 }\end{array}$} \\
\hline AG-10-07/3 & 0.0029 & 75 & 0.62 & 2.27 & 0.32 & 5.00 & 37 & 0.0471 & 8.30 & 0.04421 & 8.63 & 0.006815 & 1.36 & 0.32 & 51.99 & 197.87 & 43.93 & 3.71 & 43.78 & 0.59 \\
\hline AG-10-07/6 & 0.0010 & 65 & 0.58 & 1.08 & 0.78 & 0.61 & 64 & 0.0488 & 15.16 & 0.04595 & 15.91 & 0.006823 & 0.82 & 0.92 & 140.26 & 355.66 & 45.62 & 7.10 & 43.84 & 0.36 \\
\hline AG-10-07/1 & 0.0057 & 49 & 0.52 & 1.10 & 0.47 & 4.26 & 47 & 0.0483 & 6.22 & 0.04547 & 6.53 & 0.006832 & 0.90 & 0.41 & 112.77 & 146.59 & 45.15 & 2.88 & 43.89 & 0.39 \\
\hline & 0.0055 & 54 & 0.53 & 0.50 & 3.33 & 0.64 & 216 & 0.0472 & 3.11 & 0.04457 & 3.28 & 0.006847 & 0.20 & 0.90 & 60.02 & 74.03 & 44.28 & 1.42 & 43.99 & 0.09 \\
\hline & & 96 & & & & & 127 & & 2.38 & & & & 0.26 & 0.59 & 55.50 & 56.71 & & 1.09 & 44.03 & 0.11 \\
\hline AG-10-07/5 & 0.0245 & 64 & 0.66 & 0.50 & 16.34 & 0.71 & 961 & 0.0470 & 0.54 & 0.04442 & 0.58 & 0.006855 & 0.05 & 0.73 & 49.25 & 12.94 & 44.13 & 0.25 & 44.04 & 0.02 \\
\hline \multicolumn{21}{|c|}{ gabbro KJ-12-07 } \\
\hline $\begin{array}{l}\mathrm{KJJ}-12-077 / 6 \\
\mathrm{KJ}-12-07 / 3\end{array}$ & $\begin{array}{l}0.0050 \\
0.0050\end{array}$ & $\begin{array}{l}680 \\
280\end{array}$ & $\begin{array}{l}1.19 \\
0.97\end{array}$ & 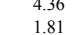 & $\begin{array}{l}27.93 \\
1624\end{array}$ & $\begin{array}{l}0.75 \\
0.52\end{array}$ & $\begin{array}{r}1439 \\
886\end{array}$ & $\begin{array}{l}0.0468 \\
0.0469\end{array}$ & $\begin{array}{l}0.37 \\
0.63\end{array}$ & $\begin{array}{l}0.03336 \\
0.03366\end{array}$ & $\begin{array}{l}0.40 \\
0.67\end{array}$ & $\begin{array}{l}0.0052020252 \\
0.005207\end{array}$ & $\begin{array}{l}0.10 \\
0.07\end{array}$ & $\begin{array}{l}0.44 \\
0.58\end{array}$ & $\begin{array}{l}38.17 \\
43.68\end{array}$ & $\begin{array}{r}8.84 \\
1512\end{array}$ & $\begin{array}{l}33.51 \\
33.62\end{array}$ & 0.13 & $\begin{array}{l}33.45 \\
33.48\end{array}$ & 0.03 \\
\hline 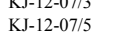 & $\begin{array}{l}0.00030 \\
0.0040\end{array}$ & $\begin{array}{l}280 \\
1265\end{array}$ & $\begin{array}{l}0.91 \\
1.17\end{array}$ & $\begin{array}{l}1.81 \\
8.23\end{array}$ & $\begin{array}{l}16.24 \\
49.51\end{array}$ & $\begin{array}{l}0.22 \\
0.65\end{array}$ & $\begin{array}{r}8566 \\
2541\end{array}$ & $\begin{array}{l}0.0469 \\
0.0469\end{array}$ & $\begin{array}{l}0.03 \\
0.21\end{array}$ & $\begin{array}{l}0.033366 \\
0.03367\end{array}$ & $\begin{array}{l}0.23 \\
0.23 \\
\end{array}$ & $\begin{array}{l}0.000207 \\
0.005208\end{array}$ & 0.06 & $\begin{array}{l}0.08 \\
0.44\end{array}$ & $\begin{array}{l}\begin{array}{l}33.68 \\
43.94\end{array} \\
-\end{array}$ & $\begin{array}{l}1.12 \\
5.12\end{array}$ & $\begin{array}{l}33.62 \\
33.63\end{array}$ & $\begin{array}{l}0.22 \\
0.08\end{array}$ & $\begin{array}{l}33.48 \\
33.48\end{array}$ & $\begin{array}{l}0.02 \\
0.02\end{array}$ \\
\hline KJ-12-07 & & 387 & 1.10 & 2.53 & 25.07 & 0.48 & 1315 & 0.0470 & 0.41 & 03372 & 0.43 & 0.005209 & 0.05 & 0.57 & 47.13 & 9.69 & 33.68 & 0.14 & 33.49 & . 0.02 \\
\hline (1) & & 338 & 1.15 & 2.24 & 22.61 & 0 & 1175 & 0.0470 & 0.46 & 3376 & 0.49 & 0.005209 & & 057 & 49 & 10.93 & 33. & 01 & 3349 & . \\
\hline $\mathrm{KJ}-12-07 / 4$ & 0.0050 & 406 & 1.15 & 2.68 & 24.41 & 0.53 & 1269 & 0.0469 & 0.47 & 0.03372 & 0.50 & 0.005213 & 0.07 & 0.47 & 44.84 & 11.21 & 33.67 & 0.17 & 33.52 & 0.02 \\
\hline \multirow{2}{*}{\multicolumn{21}{|c|}{ monzonite KJ-1 }} \\
\hline KI-10-02 & & 88 & 0.46 & 0.45 & 114.49 & & 6988 & & 0.08 & 0.03183 & 0.14 & 0.0049 & & & 33.98 & 1.89 & 31.82 & 0.04 & 31.79 & 0.04 \\
\hline$J-10=$ & 0.1160 & 186 & 0.71 & 1.02 & 107.97 & & $6 !$ & 0.0467 & & 03181 & 0.14 & 0.004944 & & & 32. & 1.9 & 31. & & 31.80 & 0.03 \\
\hline & & 372 & 0.8 & 2.07 & 18.68 & & 11 & 0.046 & & & 0.27 & 0.004947 & & & & & & & & 0.03 \\
\hline & & 460 & & & & & 4743 & & & 0.03193 & & & & & & & & & & 0.05 \\
\hline $\mathrm{KJ}-10-02 / 2$ & 0.0747 & 101 & 0.87 & 0.61 & 15.54 & 2.75 & 880 & 0.0467 & 0.28 & 0.03191 & 0.33 & 0.004952 & 0.09 & 0.63 & 35.79 & 6.74 & 31.89 & 0.10 & 31.84 & 0.03 \\
\hline \\
\hline $\mathrm{KJ}-1$ & & 331 & 0.69 & 1.39 & & 0.55 & 542 & & 1.05 & 0.02 & 1.12 & & & 0. & & 25.20 & 22.60 & 0.25 & 22.46 & 0.02 \\
\hline $\mathrm{KJ}-1$ & & 547 & 0.6 & & 13.03 & & 778 & & & & 0.79 & & & & & & 22. & & & 0.02 \\
\hline & & 5 & 0. & 2. & 13 & & 78 & & & & & & & & & 20. & & & 22.52 & 0.03 \\
\hline & & & & & 25 & & & & & & & & & & & & & & & 0.01 \\
\hline KJ-12-11A/1 & & 1108 & 0.64 & 4.35 & 46.36 & 0.73 & 2706 & 0.0464 & 0.22 & 0.0229 & 0.26 & 0.003578 & & & & & 22.5 & & 23.02 & 0.03 \\
\hline $\mathrm{KJ}-12-11 \mathrm{~A} / 3$ & 0.0040 & 268 & 0.73 & 1.58 & 9.22 & 0.62 & 541 & 0.0468 & 1.15 & 0.03117 & 1.21 & 0.004832 & 0.13 & 0.51 & 38.30 & 27.50 & 31.16 & 0.37 & 31.07 & 0.04 \\
\hline \\
\hline & & 646 & & & 14.0 & & ${ }^{84}$ & & & 0.02225 & 0.70 & & & & 35.94 & & & & & 0.02 \\
\hline & & & & & & & & & & & & & & & & & & & & 0.02 \\
\hline & & $\begin{array}{l}982 \\
251\end{array}$ & & 4. & 5 & & . & & & & 0.54 & & & & 41. & & & & & 0.03 \\
\hline & & & & & 33 & & & & & & & & & & & & & & & 0.03 \\
\hline & & 2105 & & & & & & & & & & & & & & & & & & .09 \\
\hline & & & & & & & & & & & & & & & & & & & & $.02 \mathrm{Cl}$ \\
\hline & & & & & & & & & & & & & & & & & & & & .02 \\
\hline Ll-10-03/2 & 0.0095 & 750 & 0.62 & 3.12 & 9.02 & 2.96 & 551 & 0.0467 & 0.40 & 0.02256 & 0.44 & 0.003506 & 0.09 & 0.63 & 31.90 & 9.46 & 22.65 & 0.10 & 22.56 & 0.02 \\
\hline
\end{tabular}

(a) AG-10-06/1, 2 etc. are labels for single zircon grains or fragments; all zircons annealed and chemically abraded after Mattinson (2005).

(b) Nominal fraction weights measured after chemical abrasion.
(c) Nominal $\mathrm{U}$ and total Ph concentrations subject to uncertainty in weighting zircons.

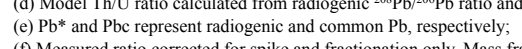

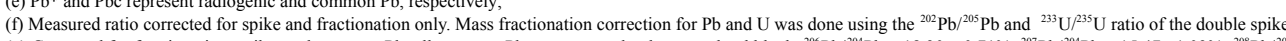

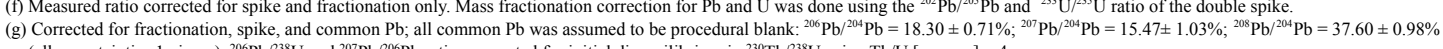

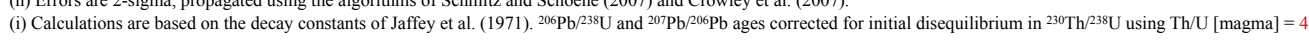




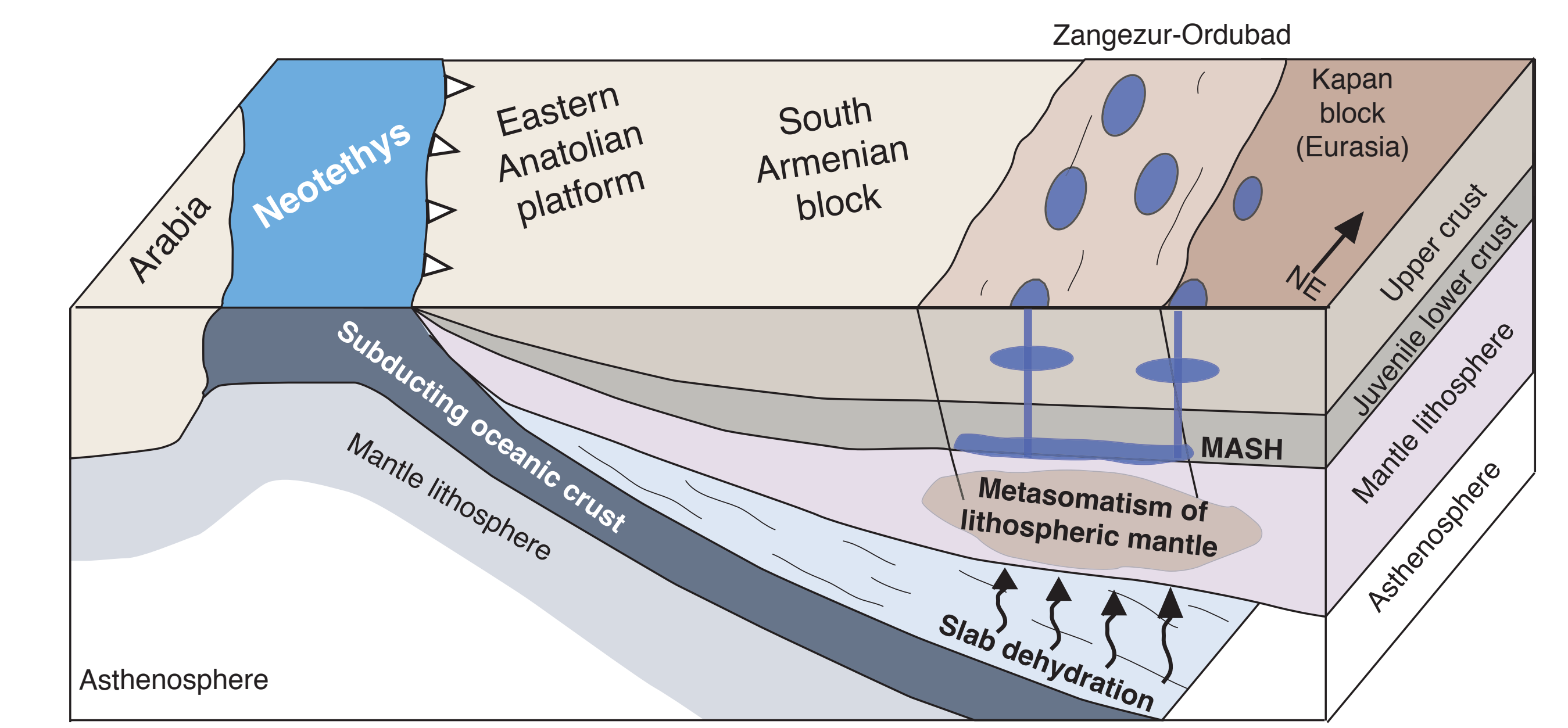

1: Eocene subduction-related arc magmatism and first generation porphyry $\mathrm{Cu}-\mathrm{Mo}$ deposits

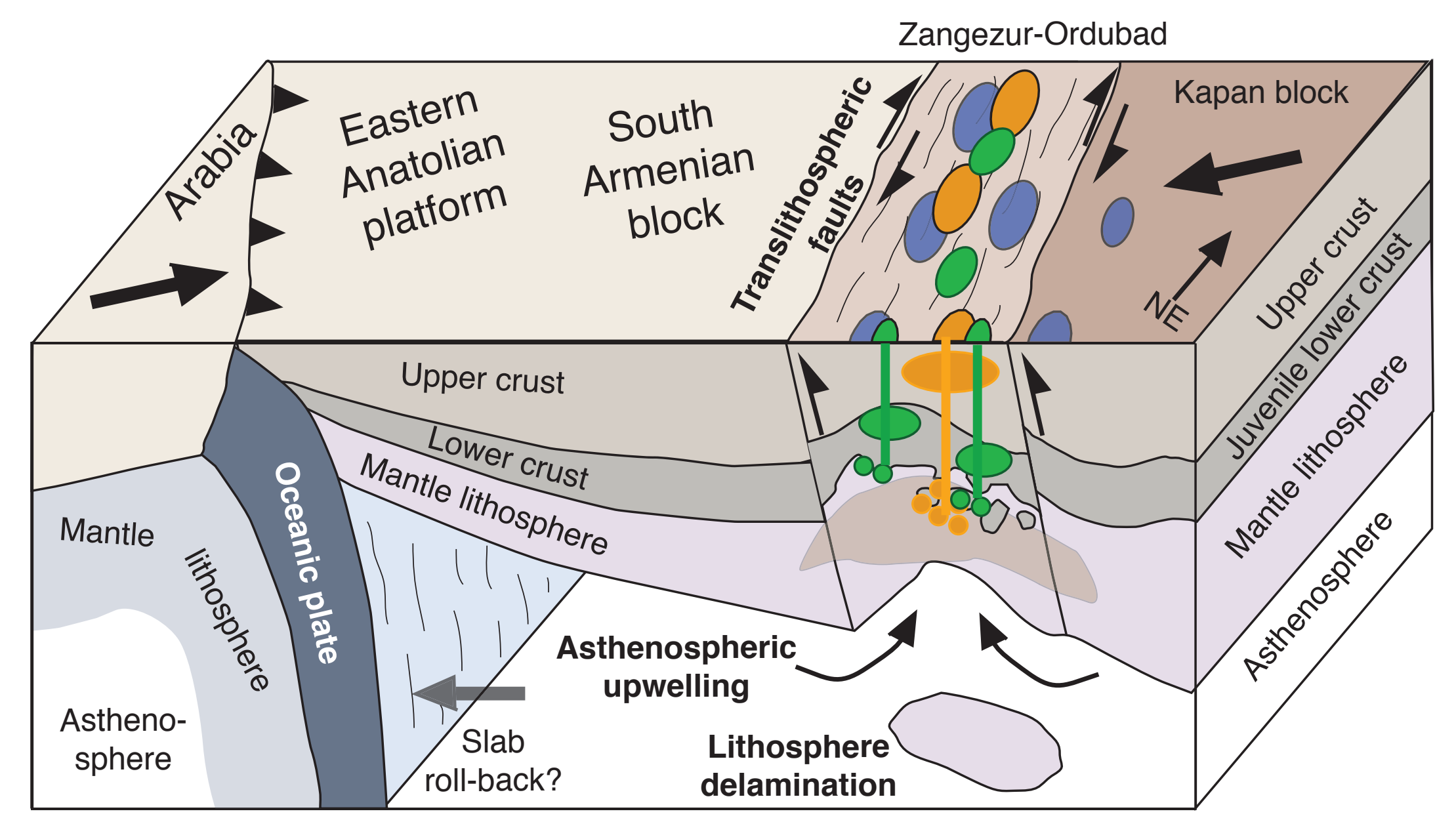

2: Early Oligocene high-K calc-alkaline and shoshonitic to late Oligocene and Mio-Pliocene adakitic magmatic evolution and late, collision to post-collision porphyry Cu-Mo deposits 